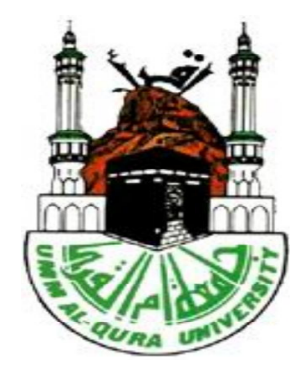

\title{
تهقيق هiطوط
}

القول الأحرى في الطلاق المعلق على نفقة العدة بالإبرا

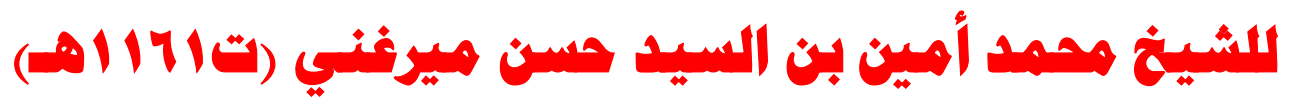

هن علمهاء هكة الاكرهة في القرن الثاني عشر الهمري

\author{
إعداد الاكتورة \\ حصة بنت عبد العزيز السديس \\ الأستاذ المشارك بقسم الشُريعة بكلية الثريعة والدراسات الإسلامية

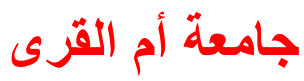


تحقيق مخطوط القول الأحري في الطلاق المعلق علي نفقة العدة بالإبرا للثيخ محمد أمين بن السيد

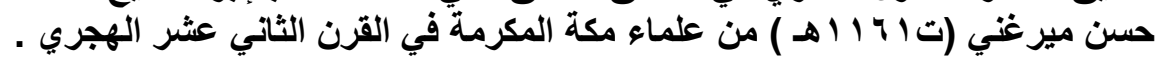


مجلة كلية الثريعة والقانون بتفهنا الأشر اف ـ دقهلية العدد الثالث والعشرون لسنة اب ـ بم الجزء الثاني

\section{تحقيق مخطوط}

القول الأحرى في الطلاق المعلق على نفقة العدة بالإبرا

للشيخ محمد أمين بن السيد حسن ميرغني (ت الم 19 ( 1 هـ)

من علماء مكة المكرمة في القرن الثاني عشر الهجري

حصة بنت عبد العزيز السديس

قسم الثريعة ، كلية الثريعة والار اسات الإسلامية ، جامعة أم الثزى، المملكة العربية السعودية.

dr.hessah.s@hotmail.com : البريد الإكثروني

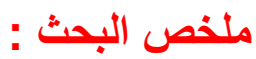

البحث هو تحقيق مخطوط (القول الأحرى في الطلاق المعلق على نفقة العدة بالإبرا) يبحث مسألة من الفتاوى الدقيقة، وهي تتعلق بالطلاق المعلق، و المسألة تناولتها

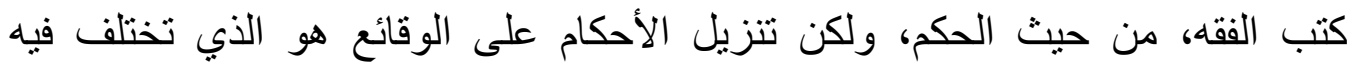

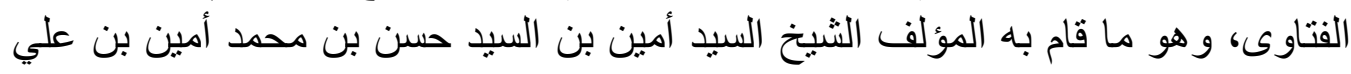

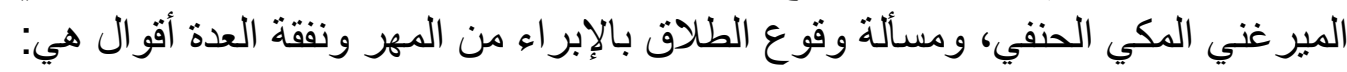

ـ عدم وقوع الطلاق المعلق بذلك، وبوقوع البراءة من المهر فقط.

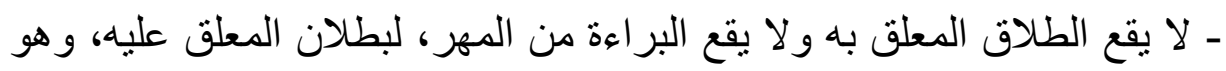

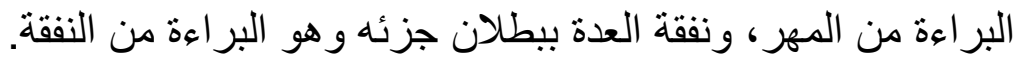
- وقوع الطلاق لصحة البر اءة من المهر ونفقة العدة. و الأخير هو ما رجحه صاحب المخطوط، واستدل له وناظر عليه. الكلمات الافتثاحية : الطلاق المعلق ، الإبراء ، نفقة العدة ، المهر ، الخلع . 


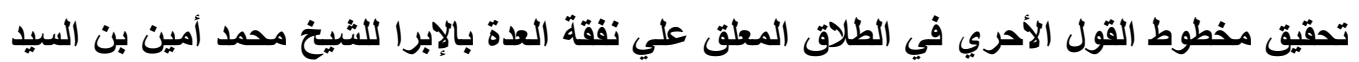

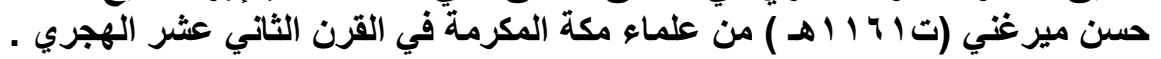

\section{Manuscript investigation}

The better say about divorce is conditional upon the expense of the waiting period with the needles

By Sheikh Muhammad Amin bin Al-Sayed Hassan

Mirghani (d.1161 A.H.)

Of the scholars of Mecca in the twelfth century AH Hessa bint Abdul Aziz Al Sudais

Department of Sharia, College of Sharia and Islamic Studies, Umm Al-Qura University, Saudi Arabia.

E-mail: dr.hessah.s@hotmail.com Abstract:

And halting the sale, which is a legal arrangement, a letter, a letter, a letter, a message, a message, a message, a message, a message, a stop, a trademark, and a trademark, and the author swallowed the author Mr. Amin bin Al-Sayed Hassan bin Muhammad Amin bin Ali Al-Mirghani Al-Makki AlHanafi, and the occurrence of divorce Withholding from the dowry and the maintenance of the waiting period, there are two statements:

- The non-occurrence of the pending divorce, and the occurrence of innocence from the dowry only.

- "The innocence ceases," and he suspended the innocence of the dowry, the maintenance of the waiting period, and he holds the innocence of the maintenance.

- The occurrence of divorce for the validity of innocence from the dowry and the maintenance of the waiting period.

And the last is what the owner of the manuscript suggested.

Key words: Pending Divorce, Release, Waiting Period, Dowry, Divorce. 
مجلة كلية الثريعة والقانون بتفهنا الأثراف ـ دقهلية العدد الثالث و العشرون لسنة إ ـ ب م الجزء الثاني

\section{بسم الله الرحمن الرحيم \\ المقدمة المة}

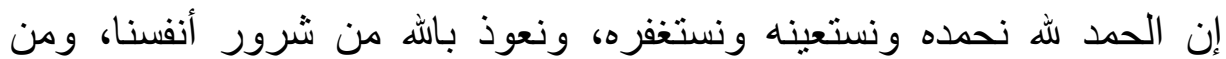

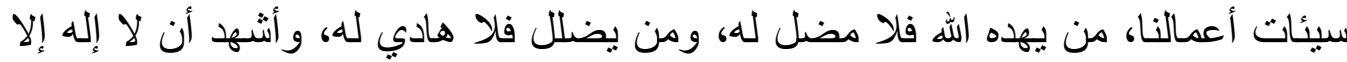

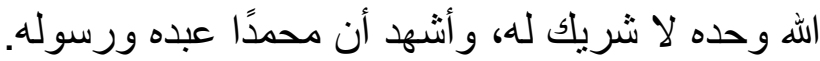

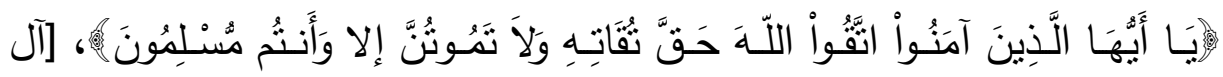

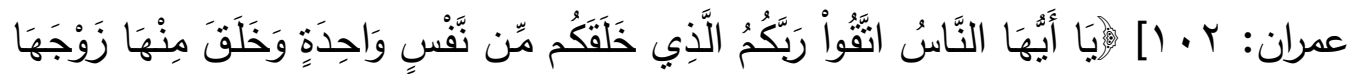

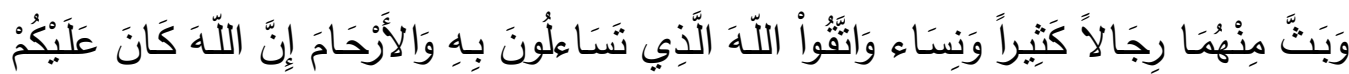

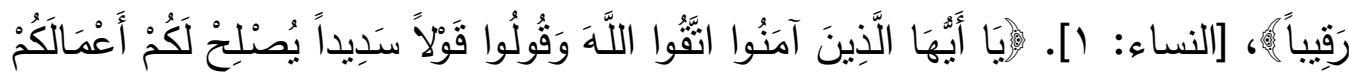

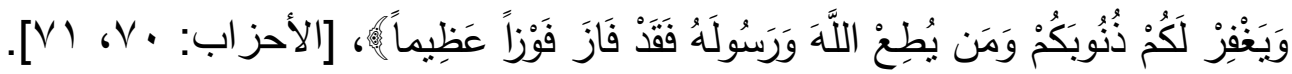

أَما بـده.

فهذا المخطوط من وضع عالم جليل من علماء الحرم المكي، ومكة المكرمة بلد

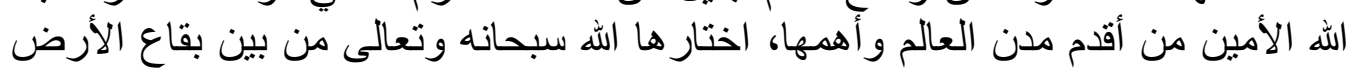

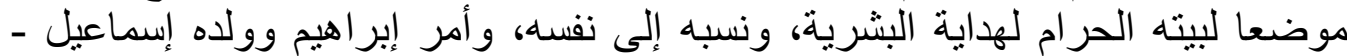

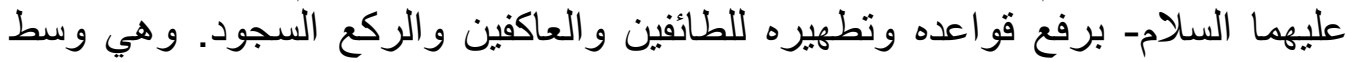

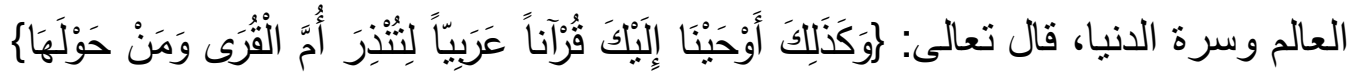

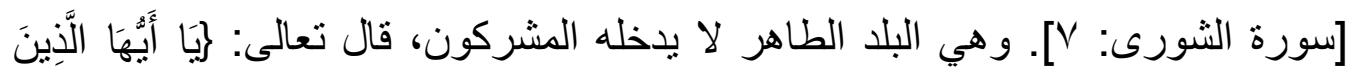

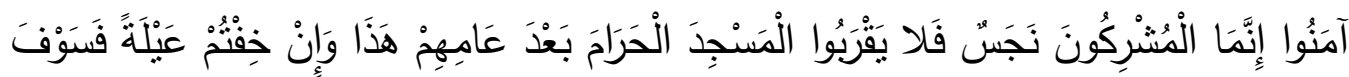

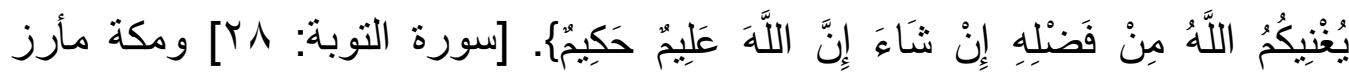

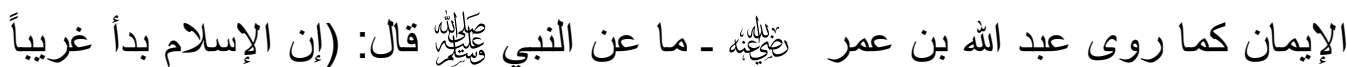
وسيعود غريباً كما كان، وهو يأرز بين المسجدين كما تأرز الحية إلى حجرها)('). كما لإنا

(') (أخرجه مسلم في الإيمان، باب بيان أن الإسلام بدأ غريبا وسيعود غريبا و إنه يأرز بين المسجدين،

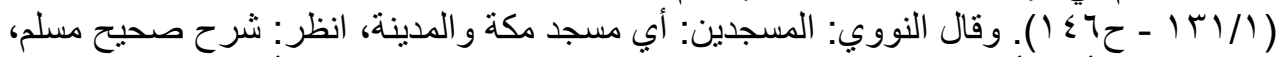

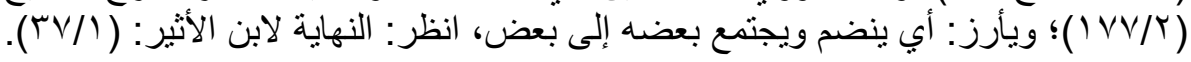


تحقيق مخطوط القول الأحري في الطلاق المعلق علي نفقة العدة بالإبرا للشيخ محمد أمين بن السيد

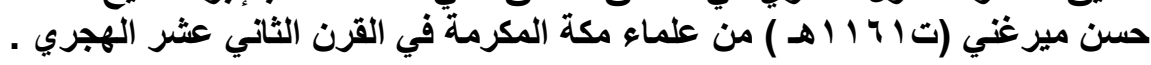

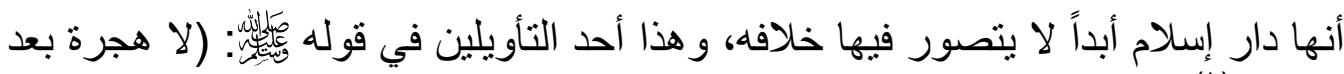
(') (الفتح) دان (1)

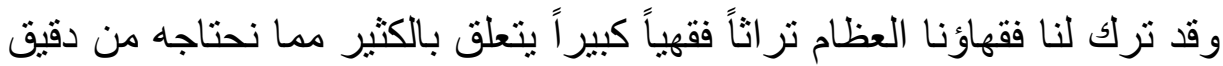

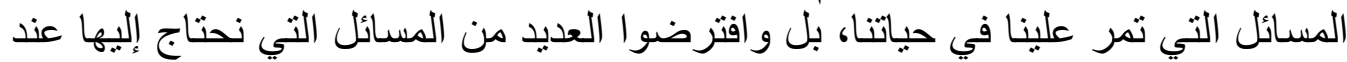

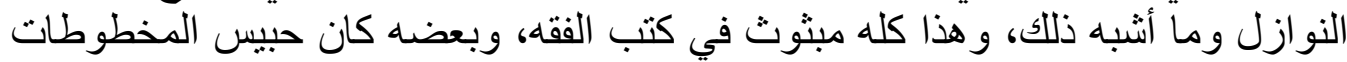

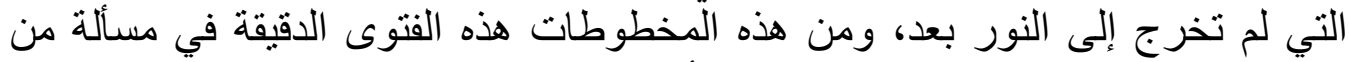

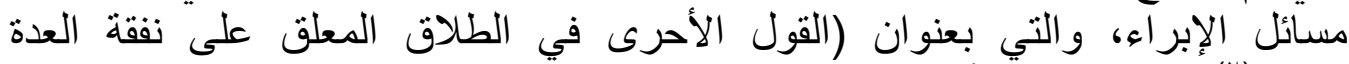

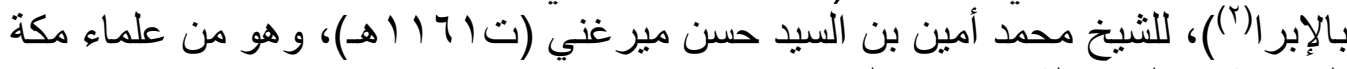
المكرمة في لقرن الثاني عشر الهجري.

\section{* . أسباب اختيار الموضوع وأهميته:}

- قد شرفني الله تعالى بسكنى مكة، فانبعثت مني الهمة لتحقيق المخطوطات التي تعنى بالنواحي الفقهية من مخطوطات علماء الحرم المكي. لمئي

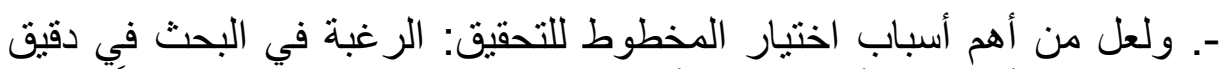

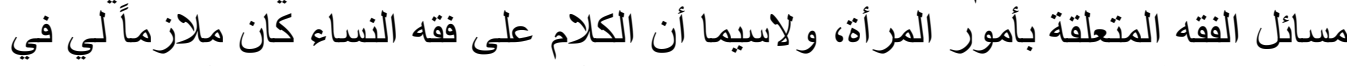

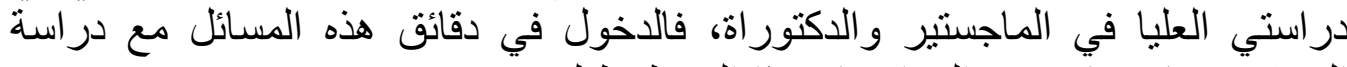

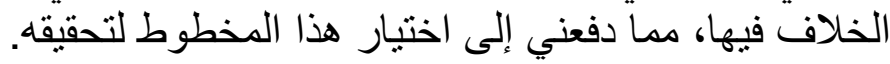

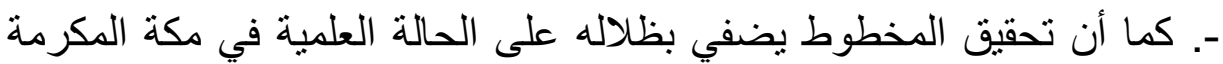

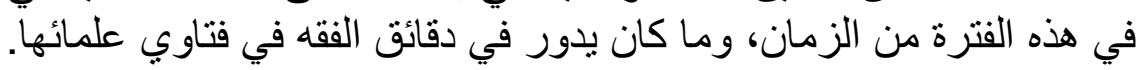

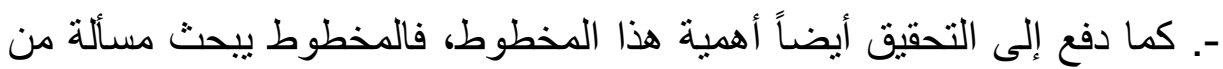

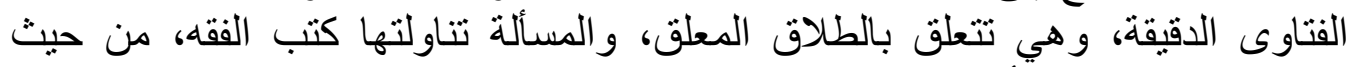

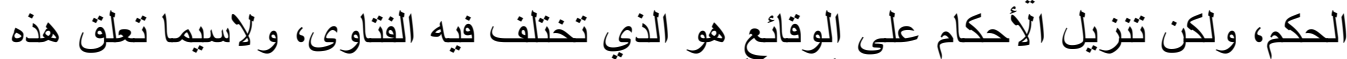

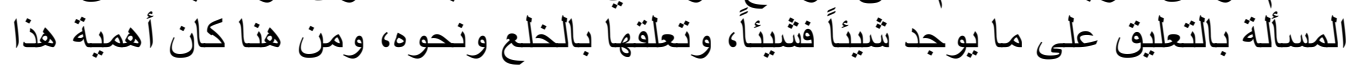
المخطوط، والله الحمد.

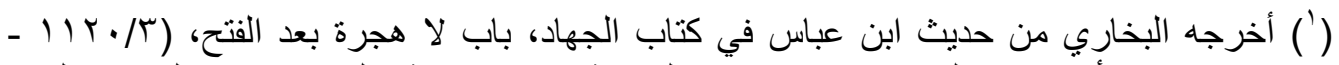

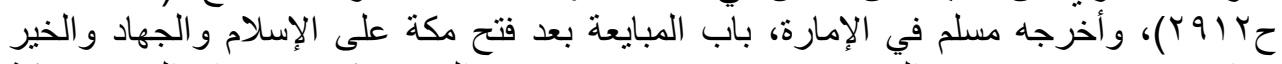

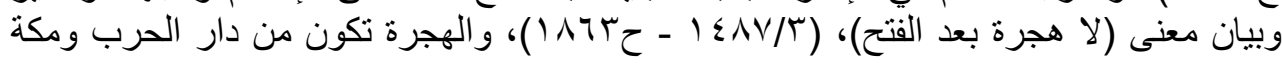

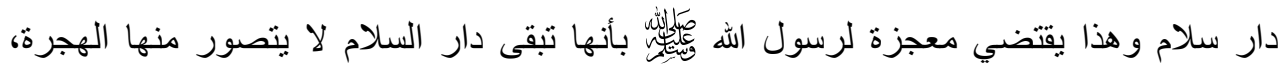

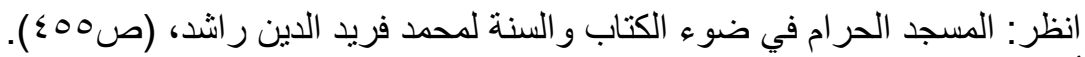

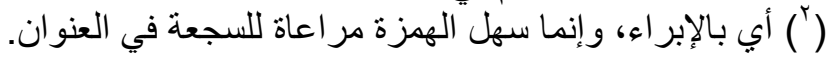


مجلة كلية الثريعة والقانون بتفهنا الأثراف ـ دقهلية العدد الثالث والعشرون لسنة اب ـ بم الجزء الثاني

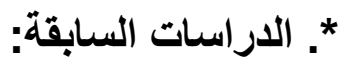

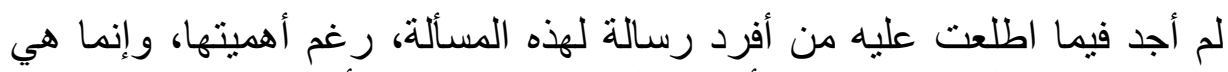
مبحوثة من خلال مسائل الإبراء العام أو مسائل الطلاق المعلق، أو الخلع في كتب الفقه

$$
\text { فحسب. }
$$

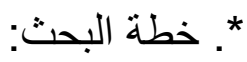

تحصل لي العمل في تحقيق هذا المخطوط من خلال الخطة التالية: - . المقدمة: وتشتمل على أسباب اخيار الموضوع وأهميته و عرض لـف للخطة.

$$
\text { - . التعريف بالمخطوط ومؤلفه. }
$$

المطلب الأول: الأوضاع العامة في مكة في القرن الثاني عشر الهجري. المطلب الثاني: نرجمة المؤلف الثيخ محمد أمين بن السيد حسن مير غني. المطلب الثالث: در اسة المخطوط. برهـ

$$
\text { - قالفهم التحقيق. }
$$

و الله أسأل أن يوفق للاستفادة من هذا المخطوط، ويكون إخراجه للنور إضافة غلى المكتبة الفقهية، وبالله التوفيق. د. حصة السديس 


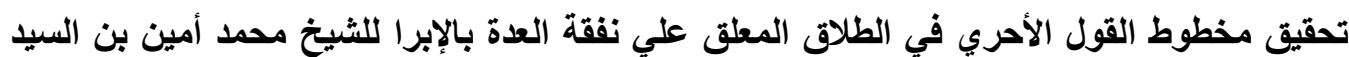

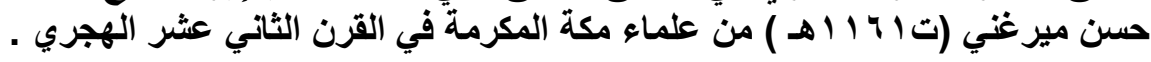

\section{. التعريف بالمطوط ومؤلفه.}

\section{المطلب 1لأول : الأوضاع العامة في مكة في القرز الثاني عشرر المجري:}

حيث كان المؤلف: هو أحد علماء مكة المكرمة في القرن الثاني الهجري، فلذا

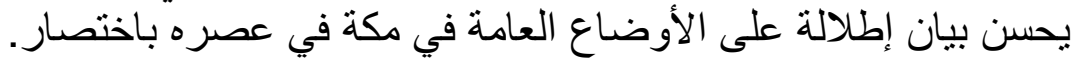

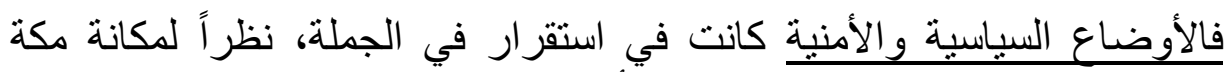

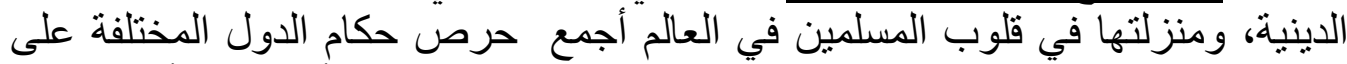

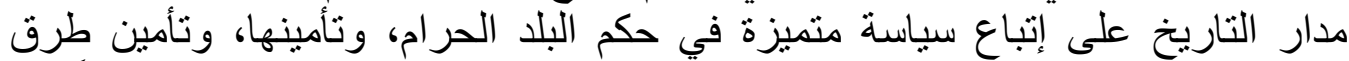

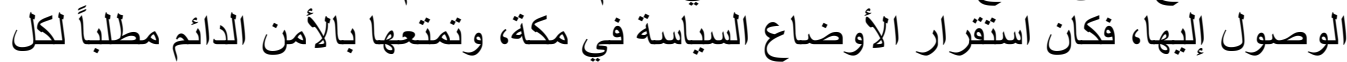

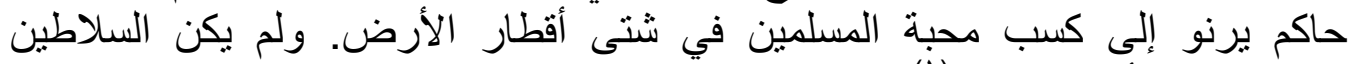

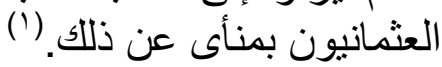

فمنذ دخول الحجاز تحت السيادة العثمانية وإعلان شريف مكة بركات(؟) تبعيته

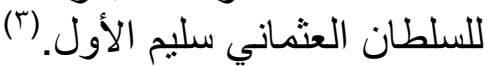

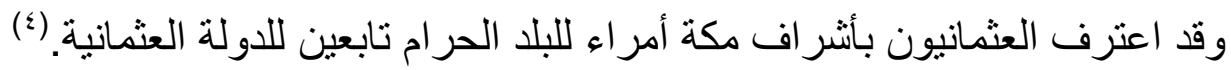

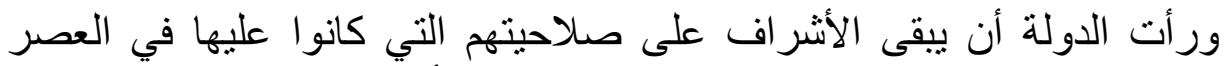

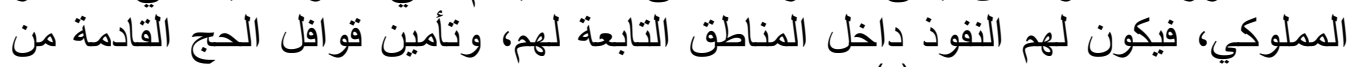

مختلف بقاع العالم الإسلامي. لمون (ن)

(') كانت الحجاز تابعة لمصر أيام المماليك، بحكم وجود الخليفة العباسي بها والذي كلف السلطان المملوكي

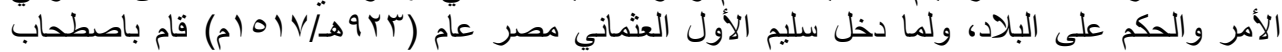

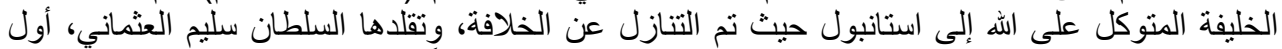

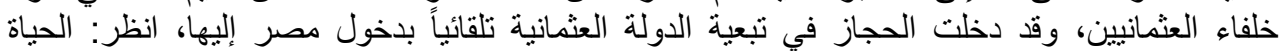

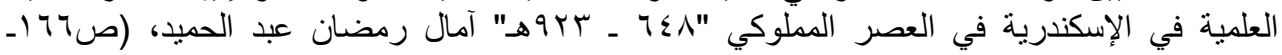

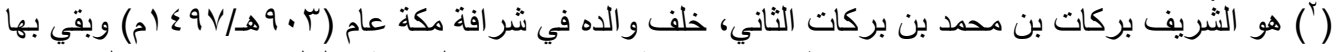

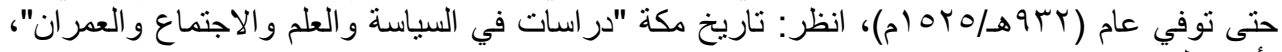

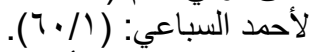

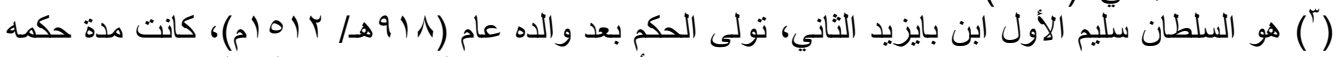

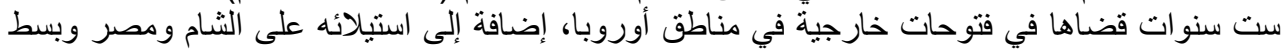

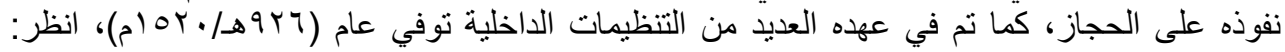

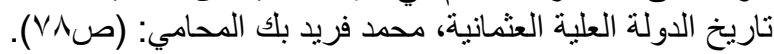

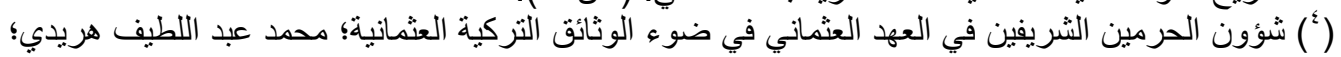

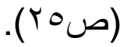
( ) الدولة العثمانية وشبه جزيرة العرب، لمحمد حراز، (ص ( • ()؛؛ الدولة العثمانية والمشرق العربي، لمحد 


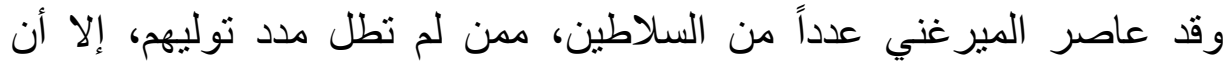

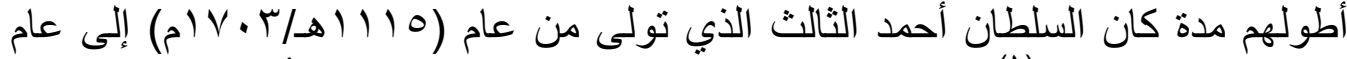

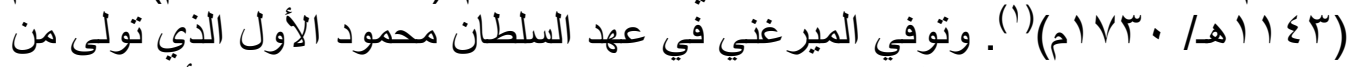

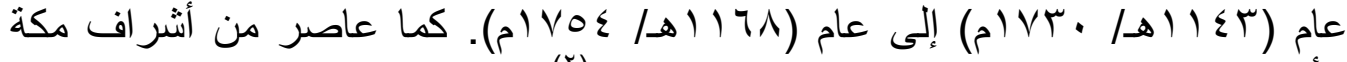

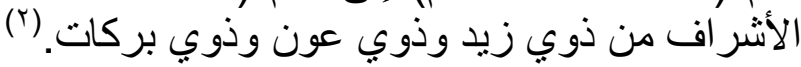

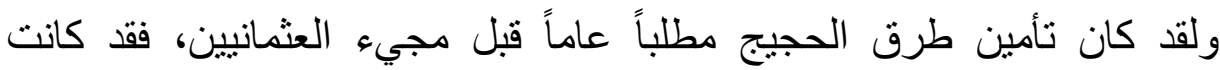

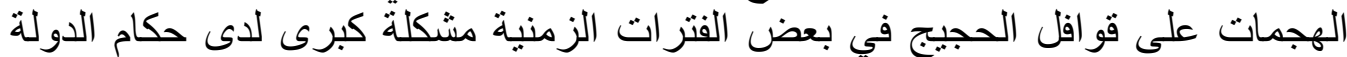

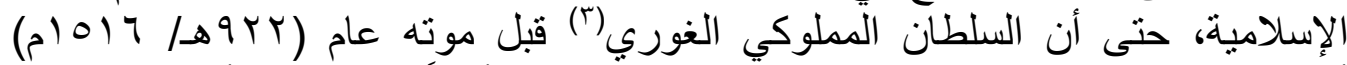

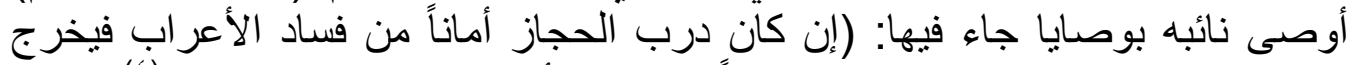

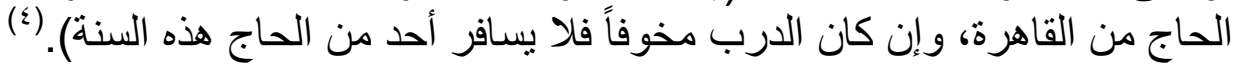

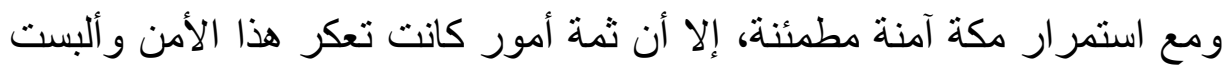

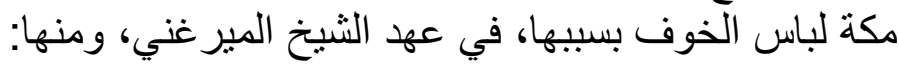

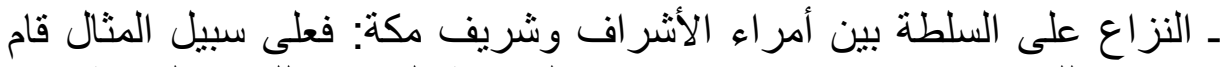

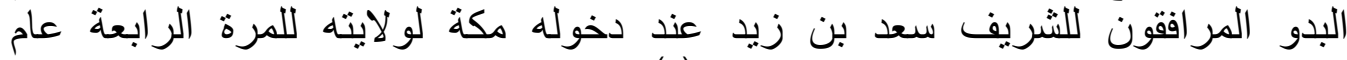

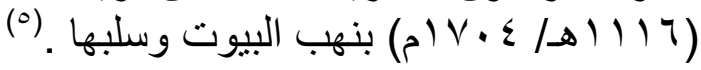

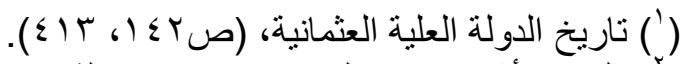

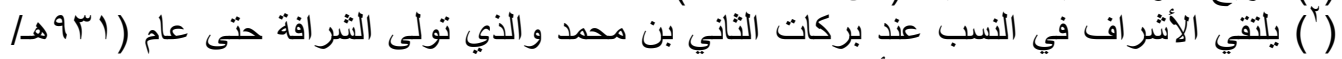

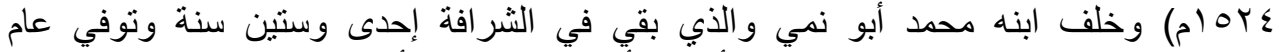

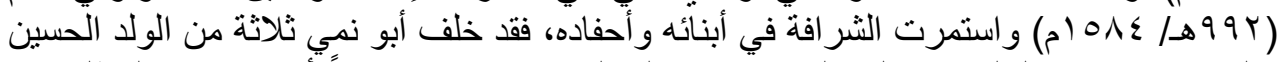

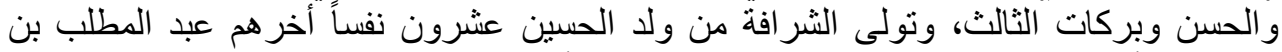

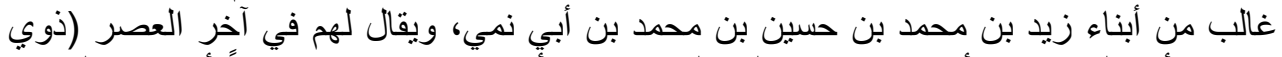

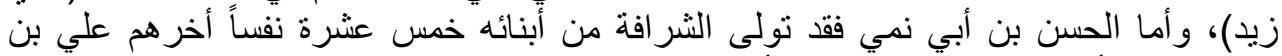

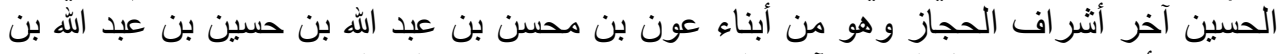

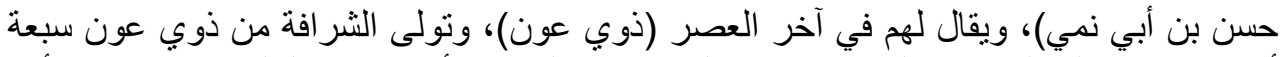

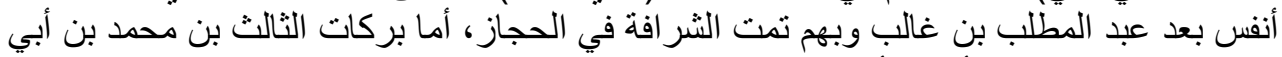

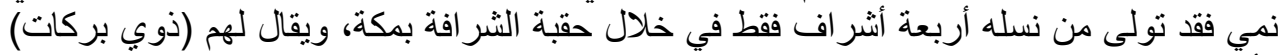

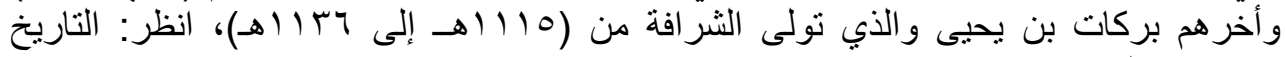

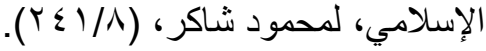

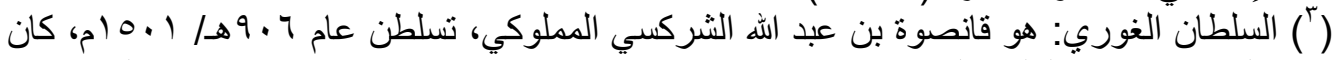

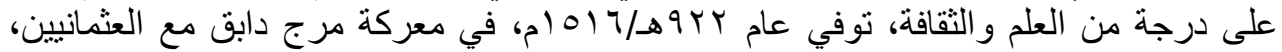

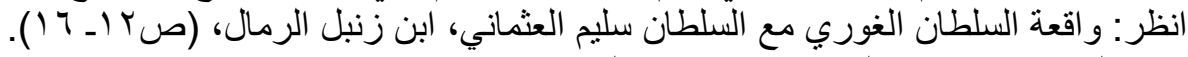

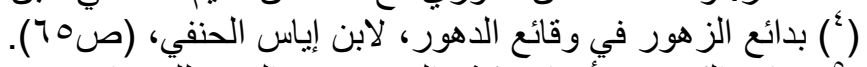

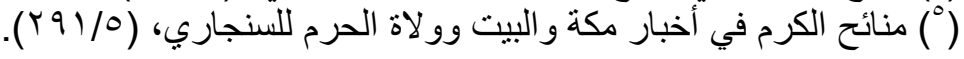




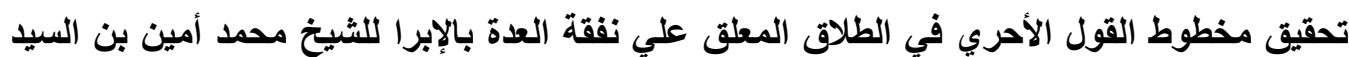

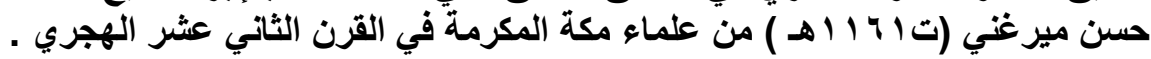

ـ هجمات الأعراب و البدو على مكة: فعلى سبيل المثال استغل الأعراب الفتن

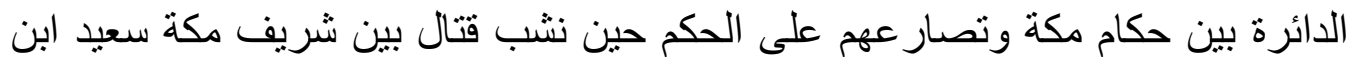

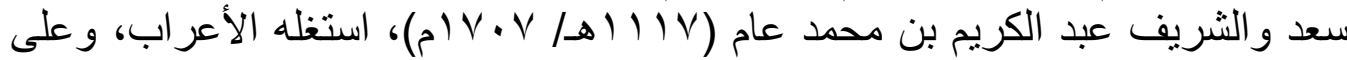

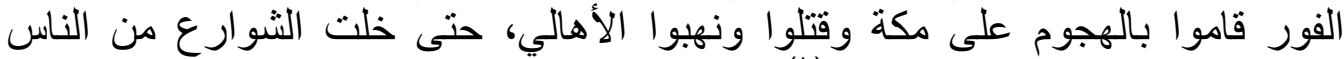
وتعطلت جميع الطرقات و الجهات. (') بالهو

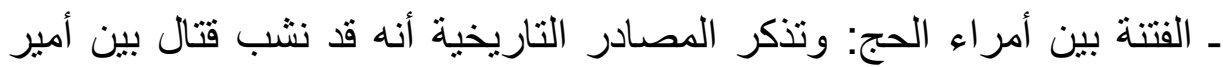

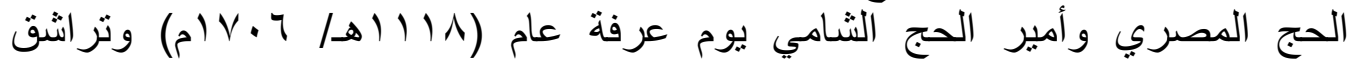

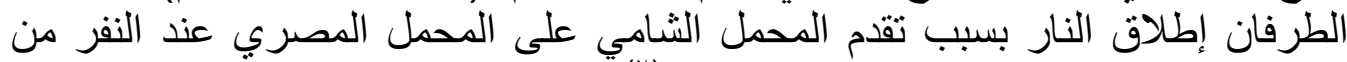

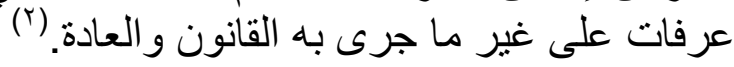

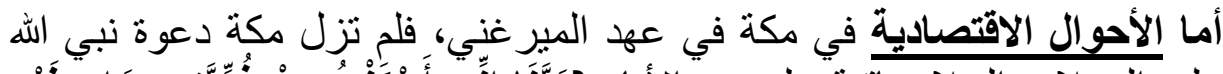

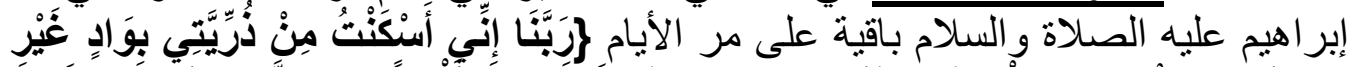

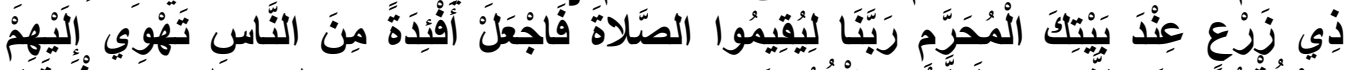

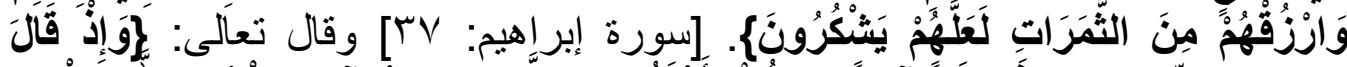

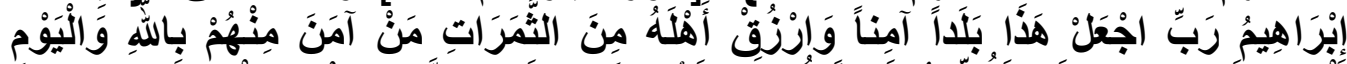

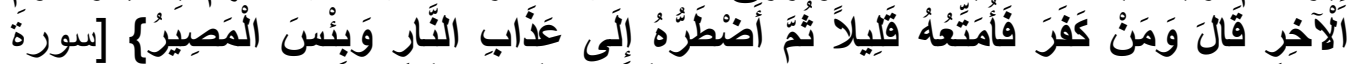

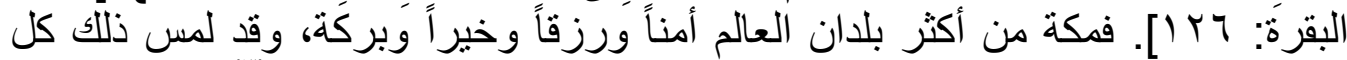

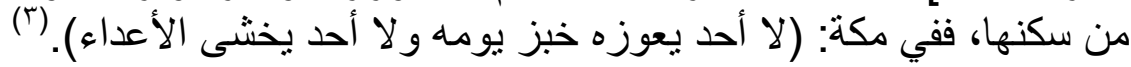

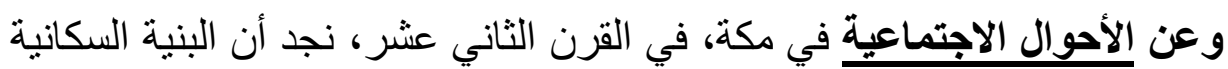

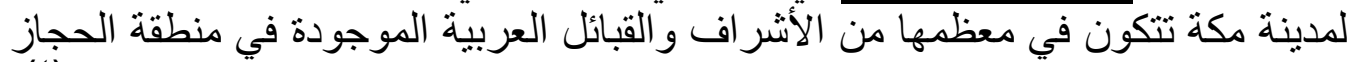

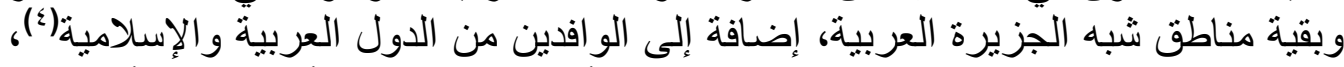

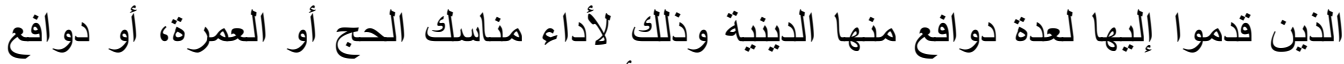

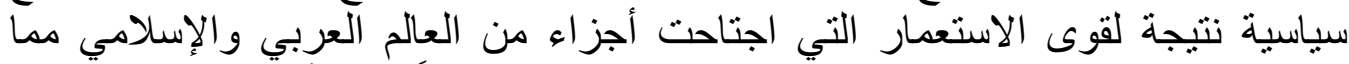

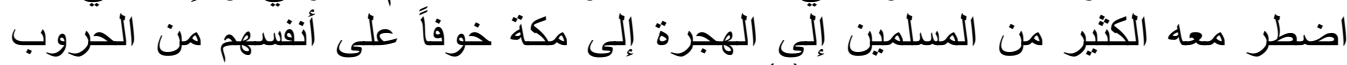

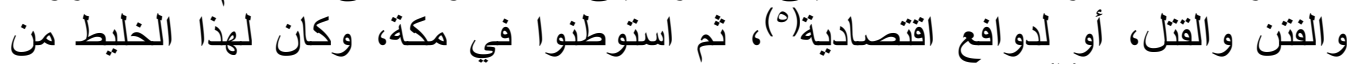

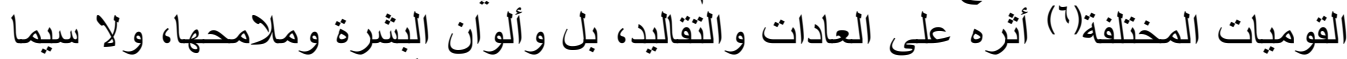

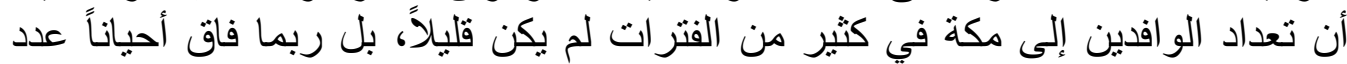

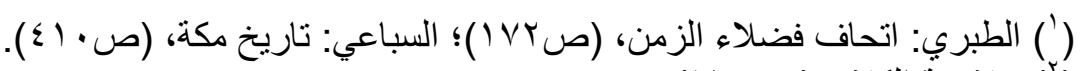

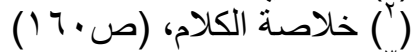

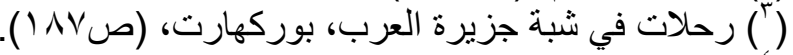

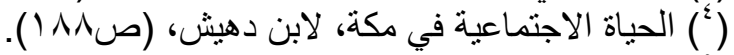

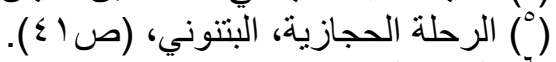

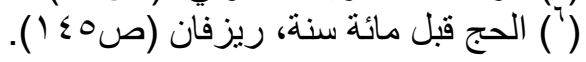




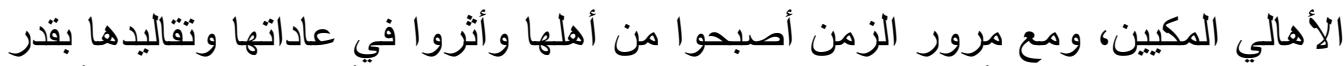

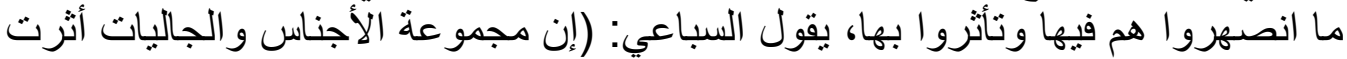

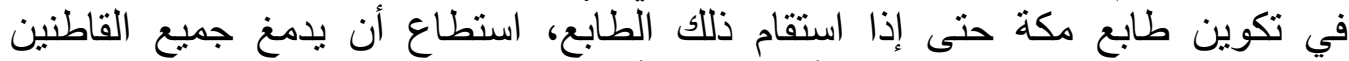

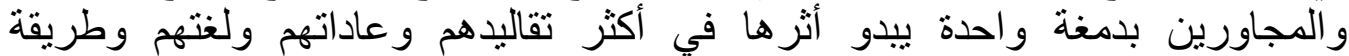

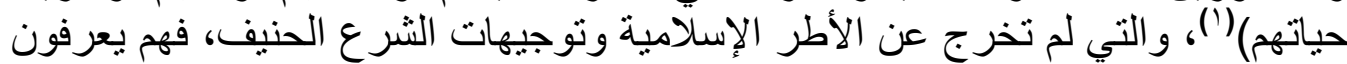

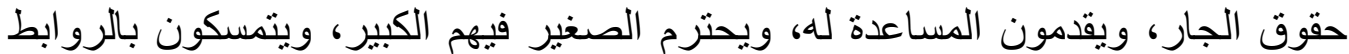

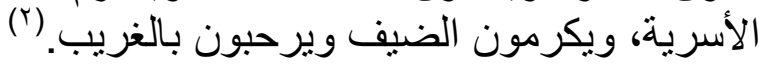

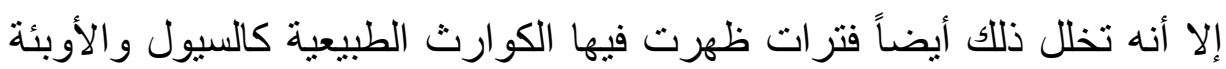

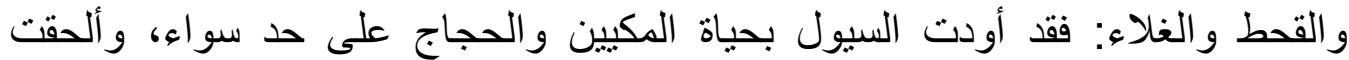

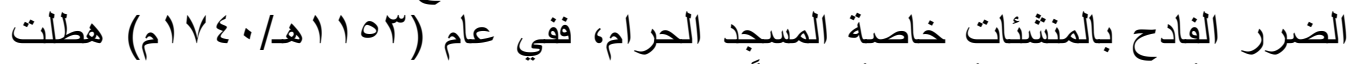

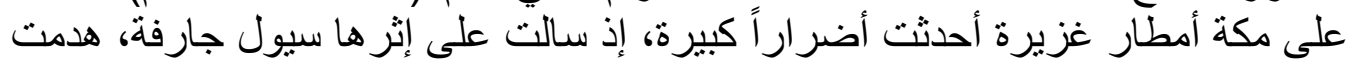

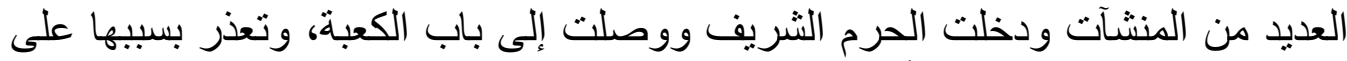

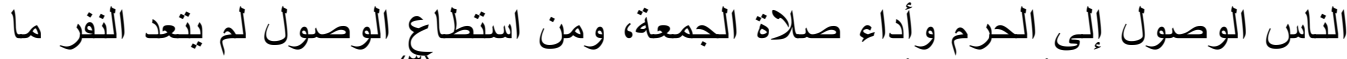

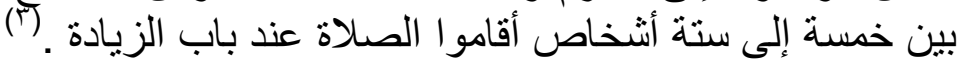

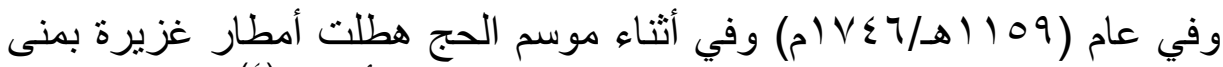

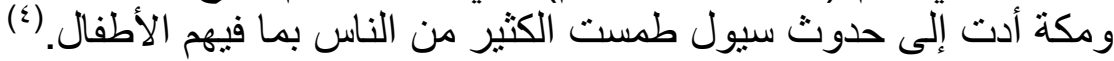

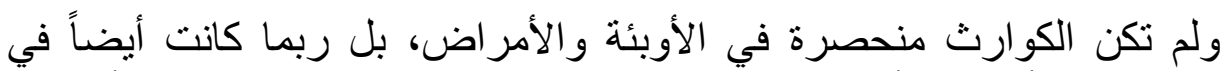

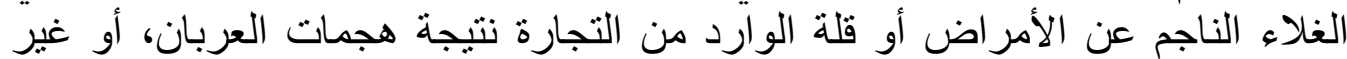

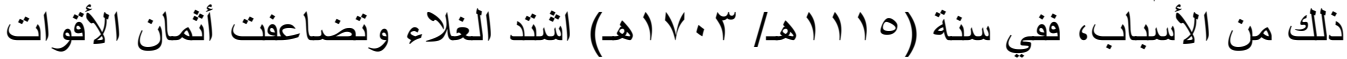

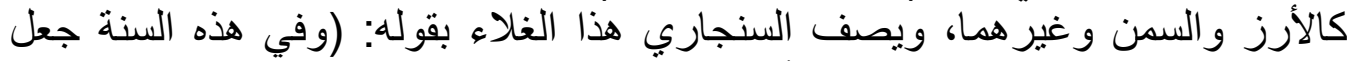

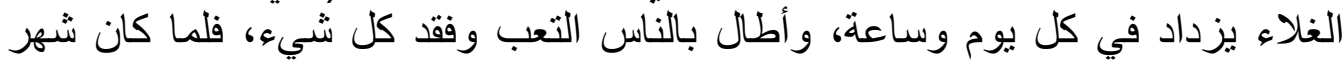

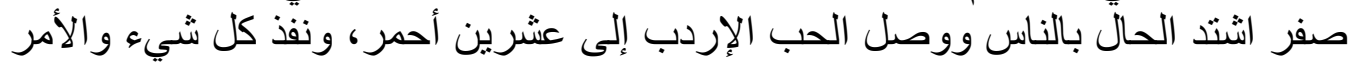

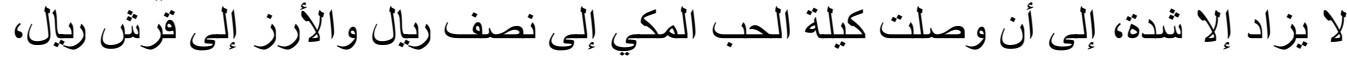

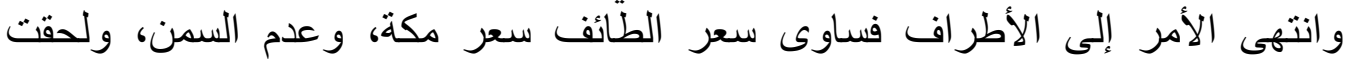


تحقيق مخطوط القول الأحري في الطلاق المطلق علي نفقة العدة بالإبرا للشيخ محمد أمين بن السيد

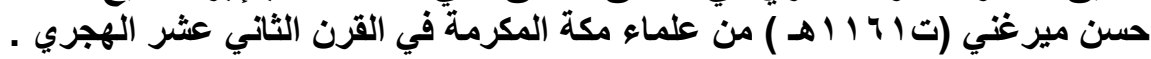

\section{المطلب الثانيي: ترجمة المؤلف الشيخخ محمد أميهن بـن السبد هسنز مير غنيى:}

*. اسمه ونسبه: يذكر السادة المراغنة، نسبتهم إلى النبي (') الهات، ومنهم

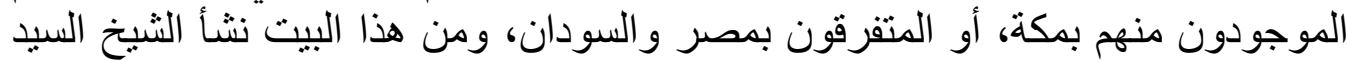

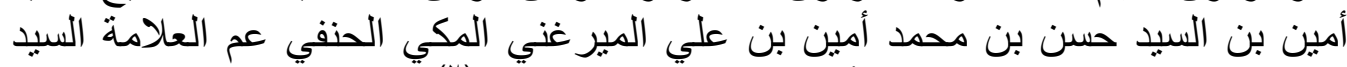

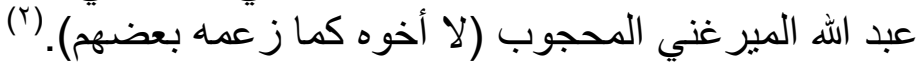

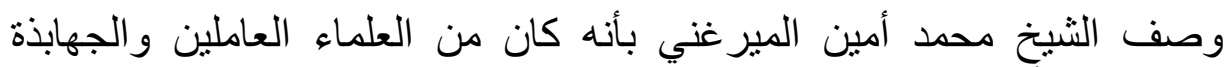

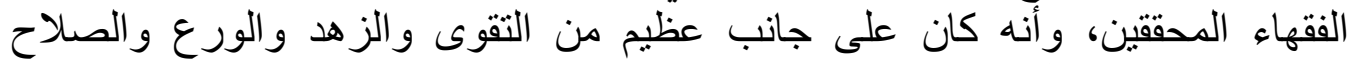
وشرف التو اضع و المجد.

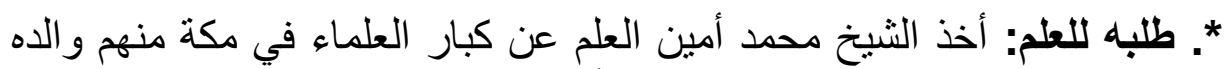

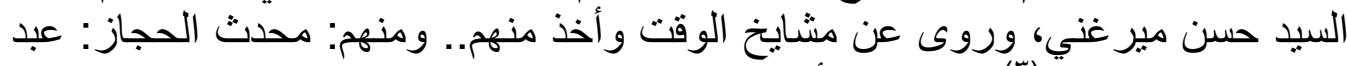

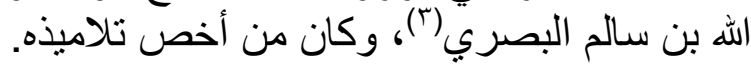

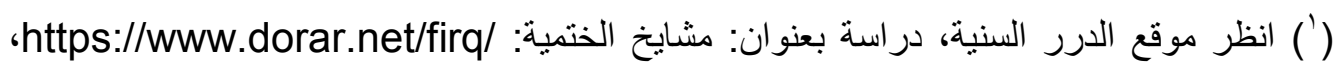

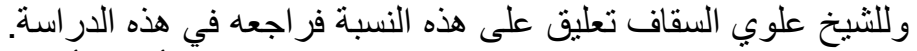

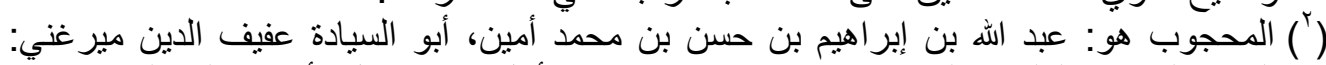

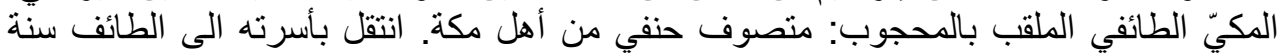

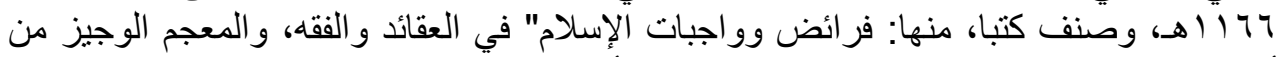

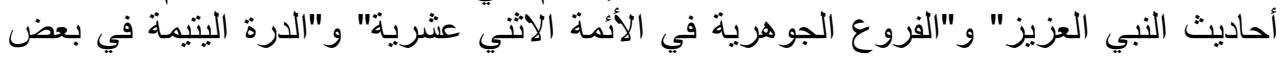

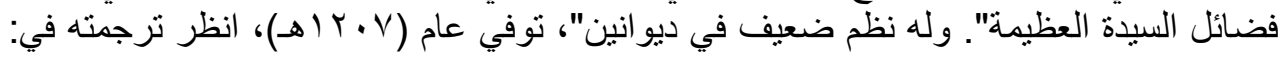

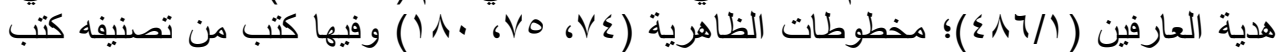

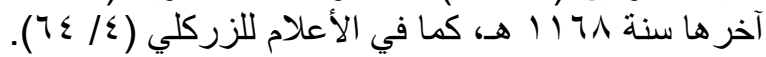

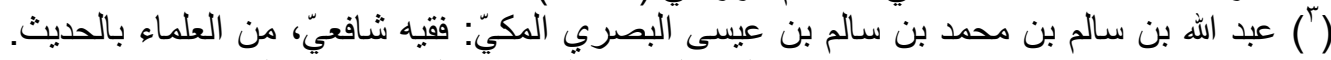

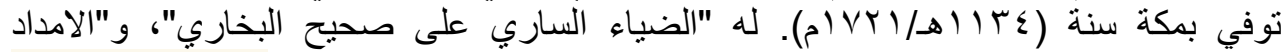

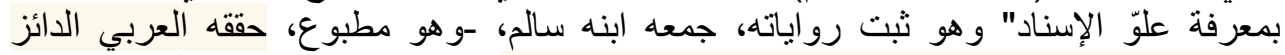

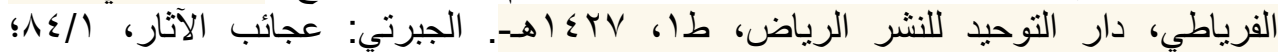

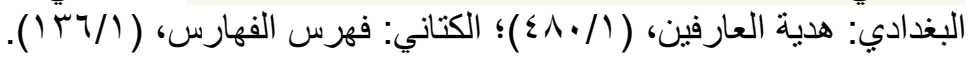




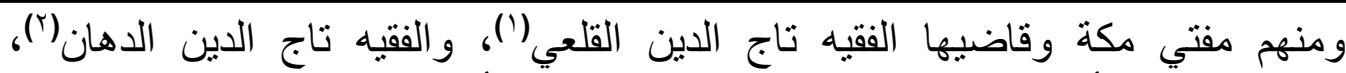

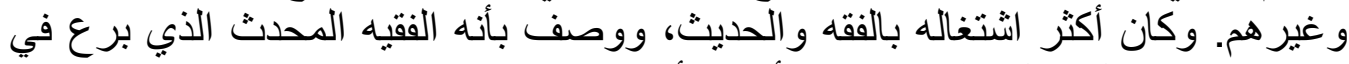
علوم الحديث، بل وكل علوم الدين، و أجاد و أفاد مما حصله ورئه على يد العلماء.

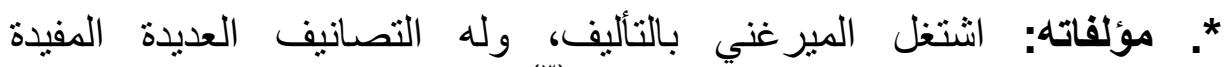

و التحرير ات النافعة منها حاثنية على شرح الزيلعي. (r)

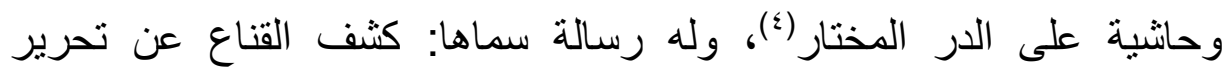

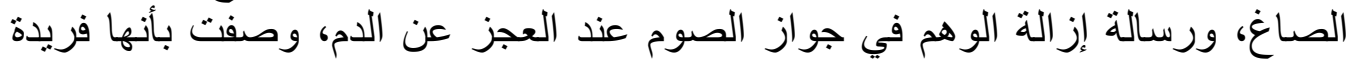

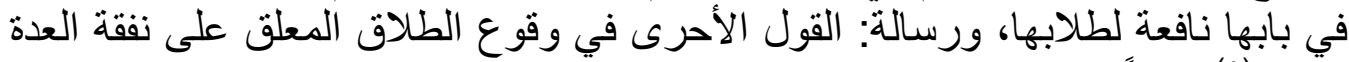

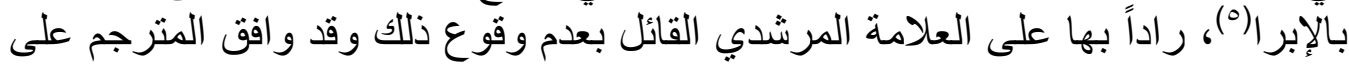

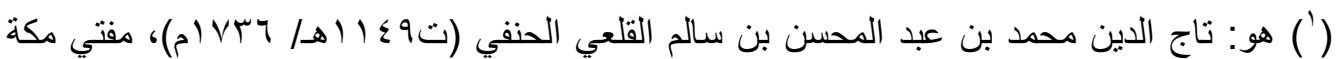

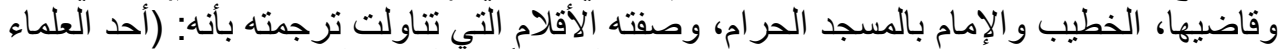

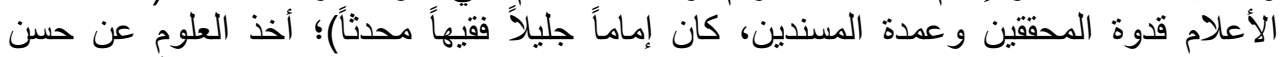

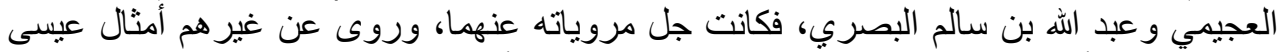

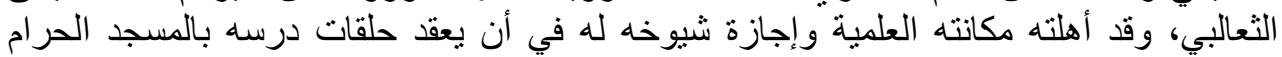

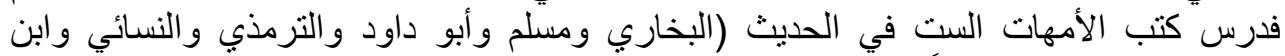

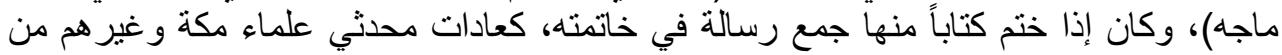

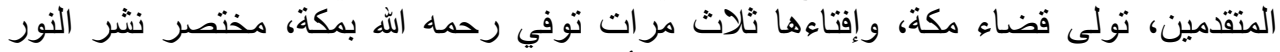

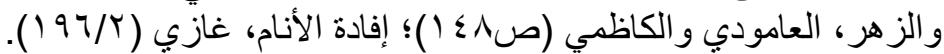

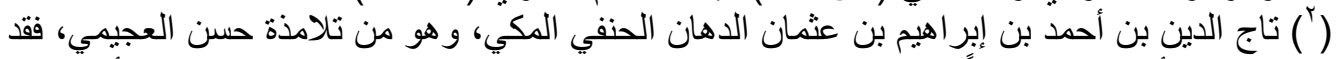

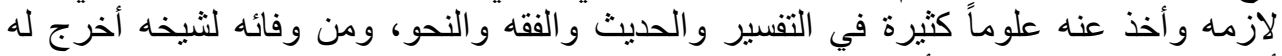

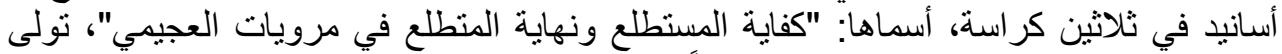

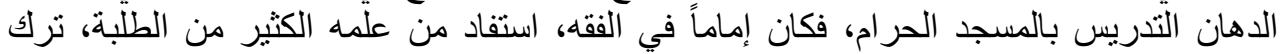

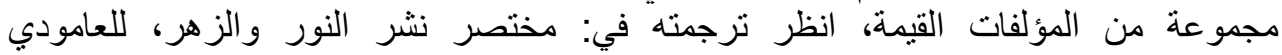

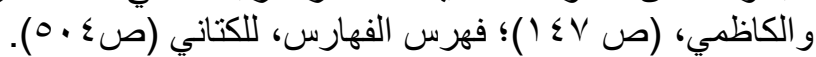

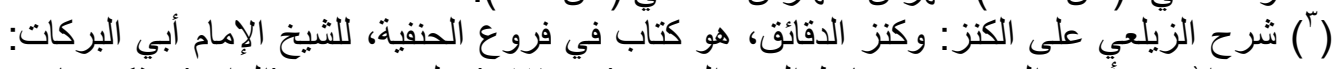

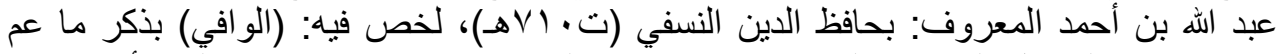

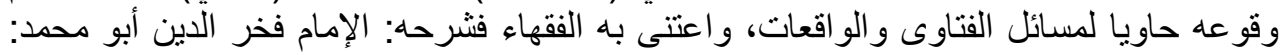

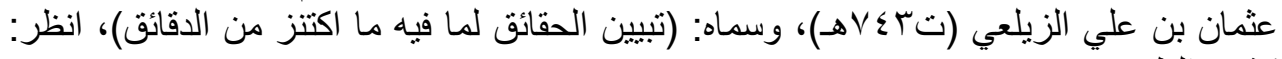

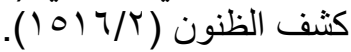

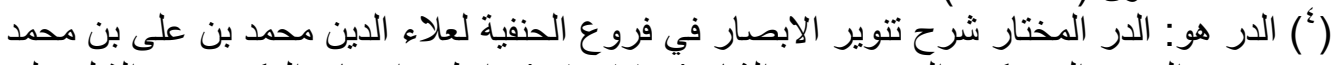

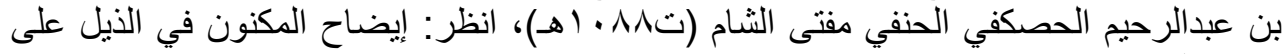

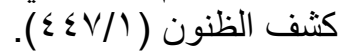
( ) وهي محل التحقيق هنا. 
تحقيق مخطوط القول الأحري في الطلاق المعلق علي نفقة العدة بالإبرا للشيخ محمد أمين بن السيد

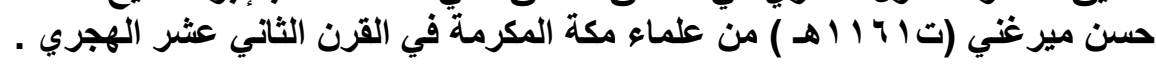

ما هنالك سائر علماء مكة وفقهائها في فتواهم وكذللك افردوا لها رسائل مستقلة.وله

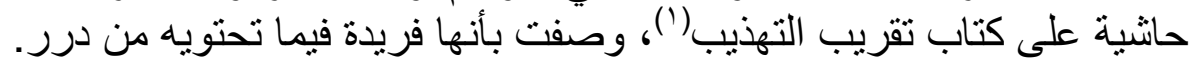

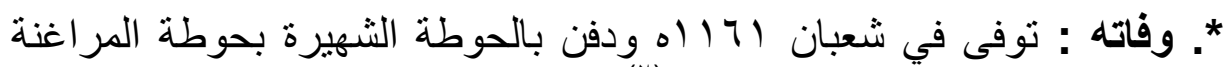

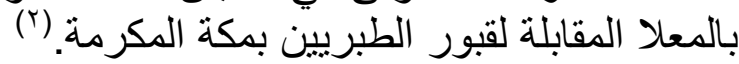

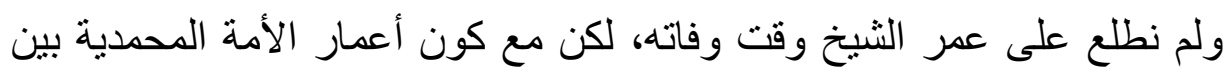

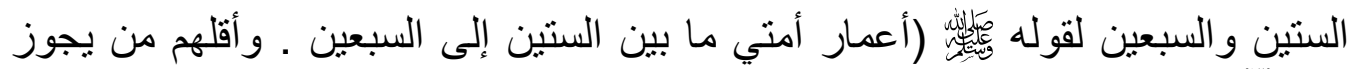

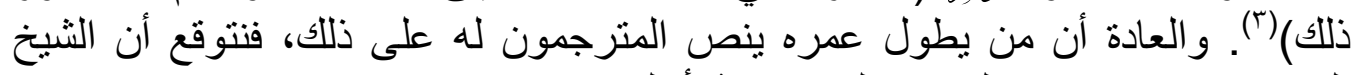

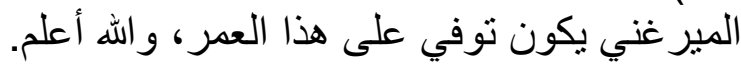

(') تقريب التهذيب: هو من مختصرات وتهذيبات كتاب الكمال في معرفة الرجال، في تراجم رجال

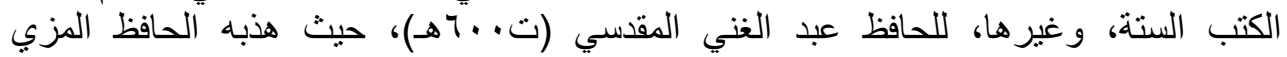

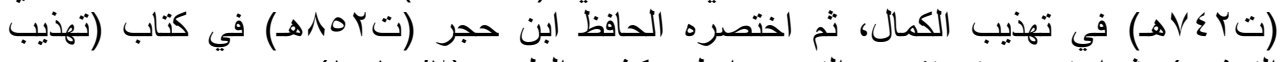

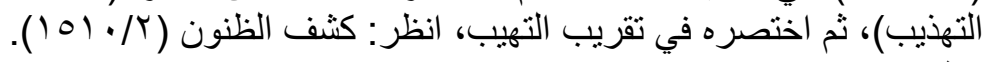

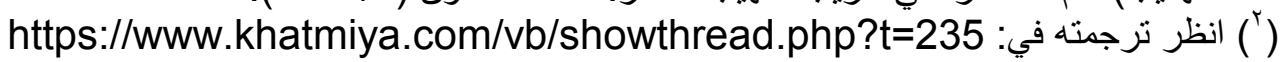
https://www.facebook.com/1456002037970671/posts/18059932763048

$77 /$.

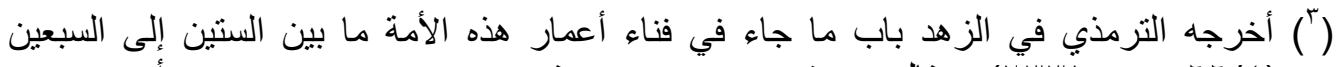

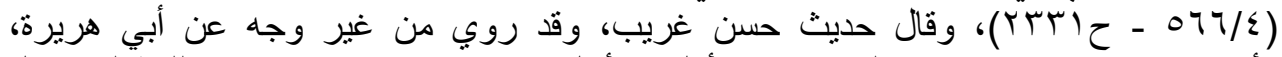

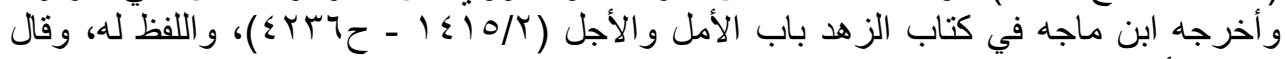




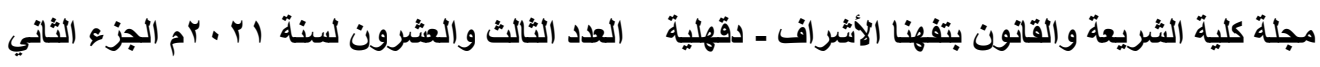

\section{المطلب الثالث: دراسة المخطوط:}

أولاً: تسمية المخطوط وصحة نسبتهُ للمؤلّفَ:

عنوان المخطوط كما جاء على صفحة الغلاف: (القول الأحرى في الطلاق المعلق على نفقة العدة بالإبرا)، و هكذا جاءت كماء تسميته في ترجمة المؤلف كما سبق.

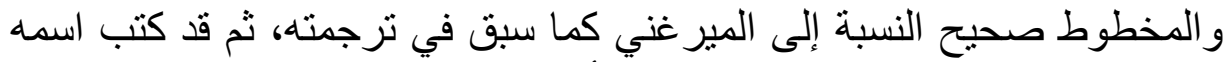

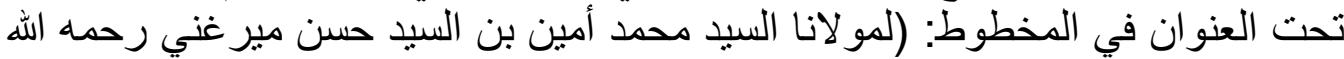

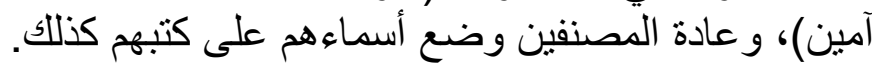
ثانياً: موضوع المخطوط، وقيمته العلمية:

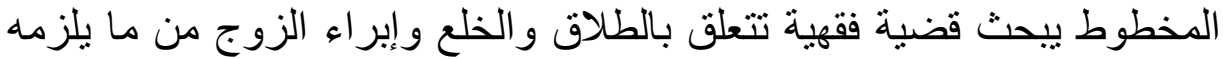
تجاهها، و الصورة التي يقع فيها الإبراء من المهر ونفقة العدة، وحتى نعلم قيمته العلمية؛

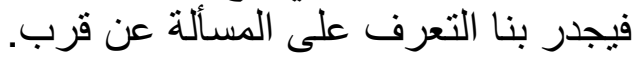
* . التعريف بمفردات العنوان:

العنوان هو: (القول الأحرى في الطلاق المعلق على نفقة العدة بالإبرا)، وفيما يلي الترف على مفرداته:

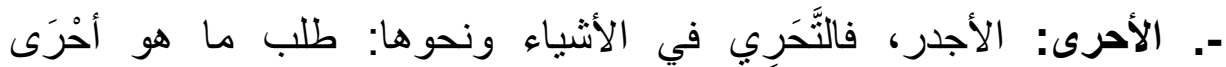

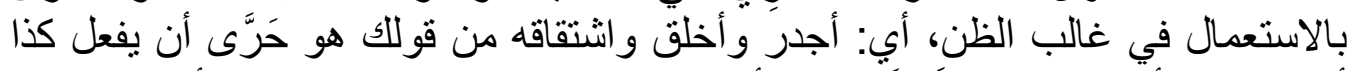

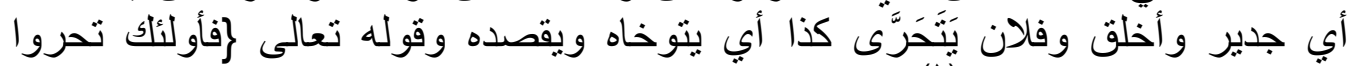

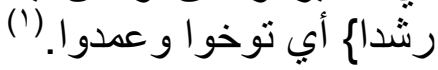

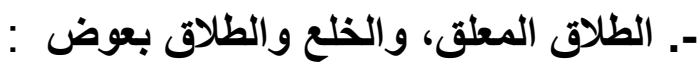

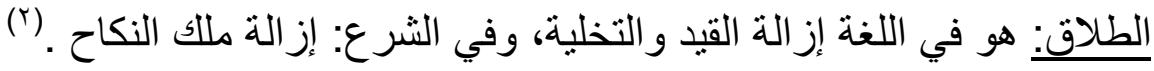

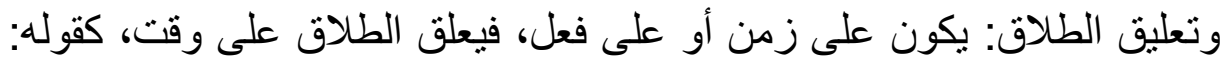

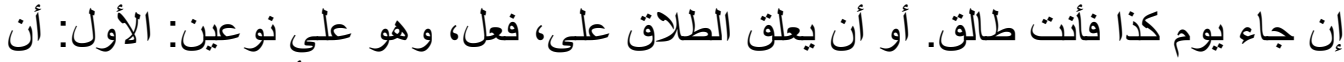

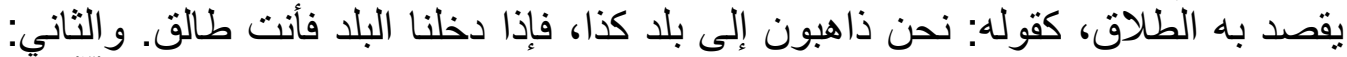

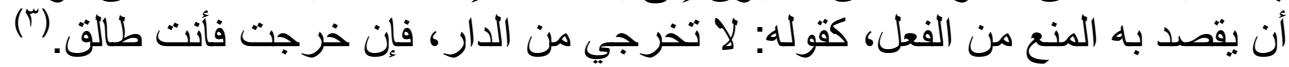

$$
\begin{aligned}
& \text { (') (') مختار الصحاح (1 (1) (1) ). }
\end{aligned}
$$

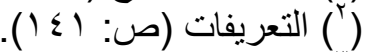

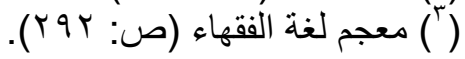




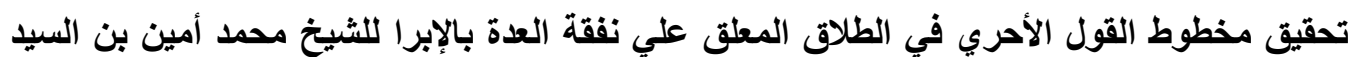

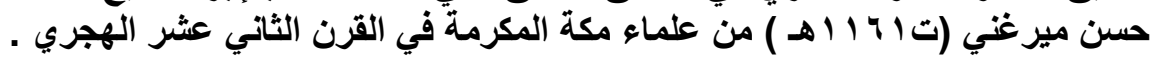

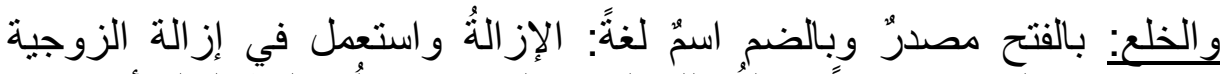

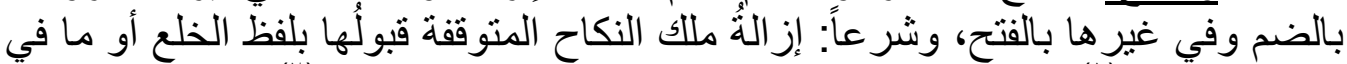

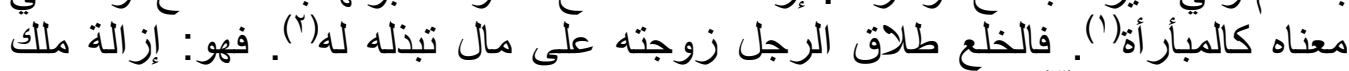

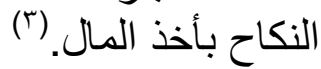

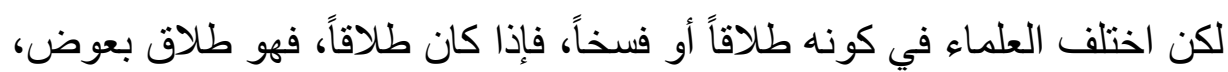

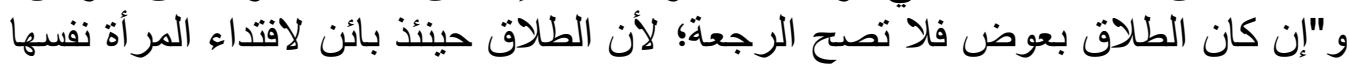

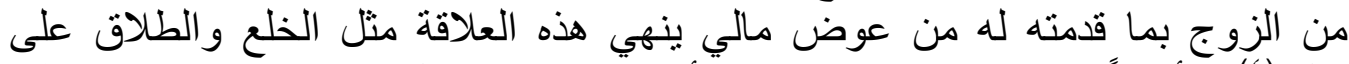

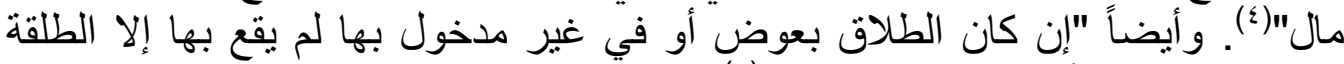

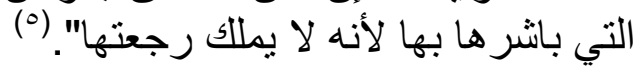

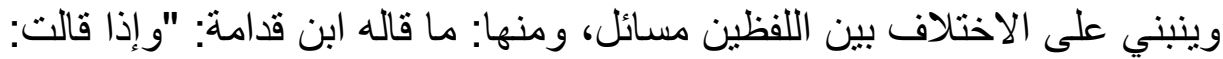

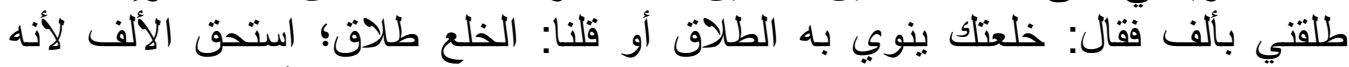

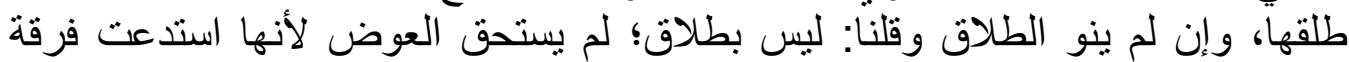

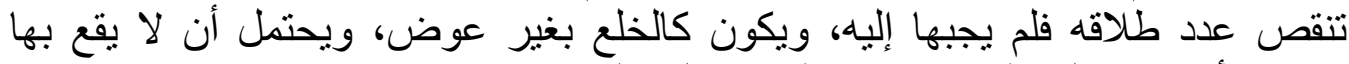

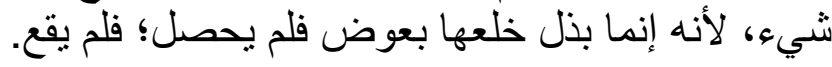

وإن قالت: اخلعني بألف فقال: طلقتك بألف وقلنا: الخلع فسن فقعيه وجهان:

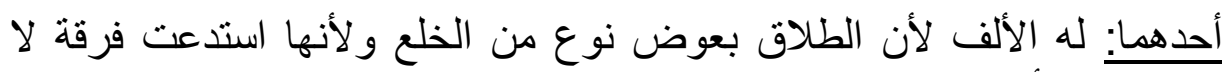

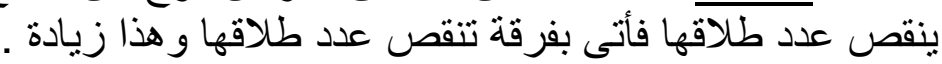

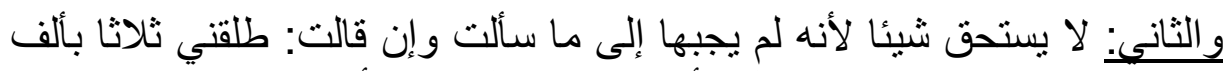

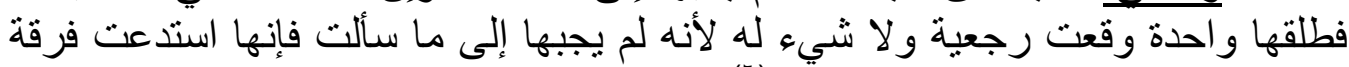

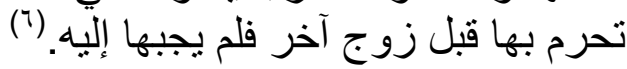

وإذا قلنا إن الخلع طلاقاً، فهو طلاق بعوض، ويأخذ أحكامه إلا أن الحنفية

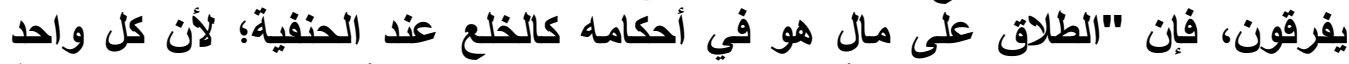

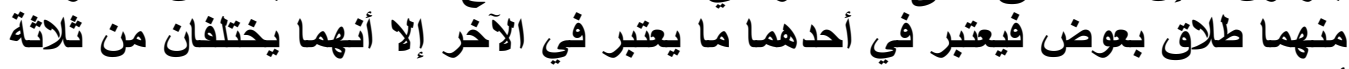

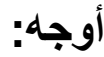


مجلة كلية الشريعة والقانون بتفهنا الأثر اف ـ دقهلية العدد الثالث والعشرون لسنة إr ـ بم الجزء الثاني

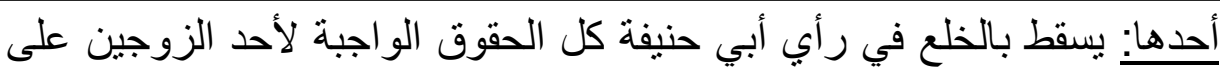

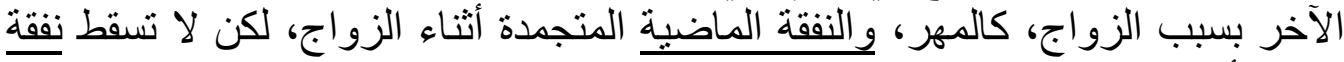

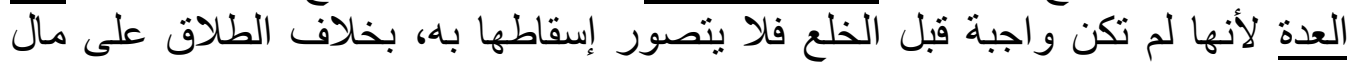

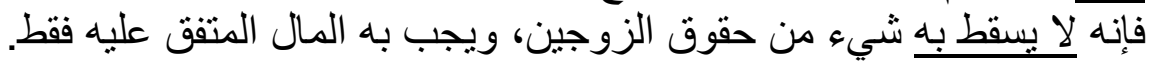

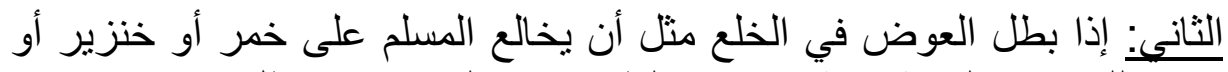

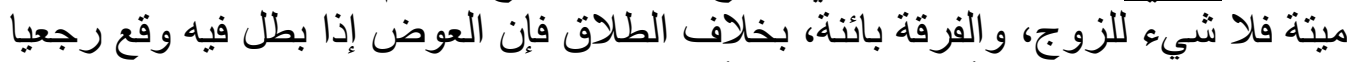

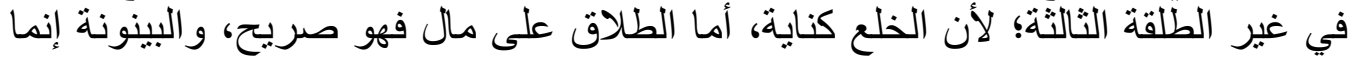

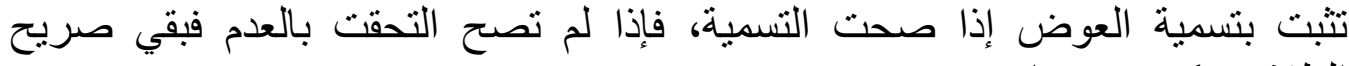
الطلاق فيكون رجعيا.

الثالث: الطلاق على مال، طلاق بائن، ينقص به عداء عدد الطلقات بلا خلاف، و وأما الخلع فالفقهاء مختلفون في كونه طلاقا ينقص بـاته، عدد الطلقات، أو فسخا لا ينقص به بله عددها. (1)

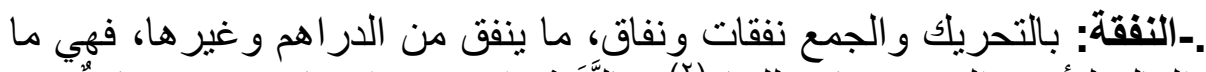

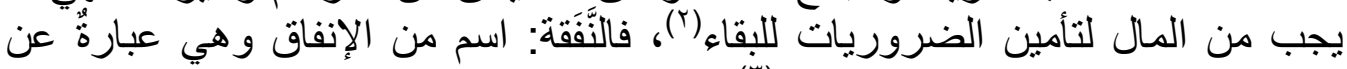

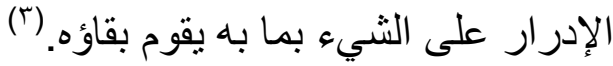

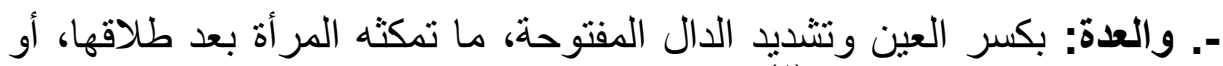

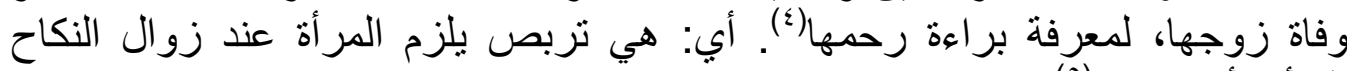

المتأكد أو شبهته. (0)

- وتفقة العدة: أب النفقة التي تكون للمر أة وقت عدتها، وقد تناول العلماء مسألة

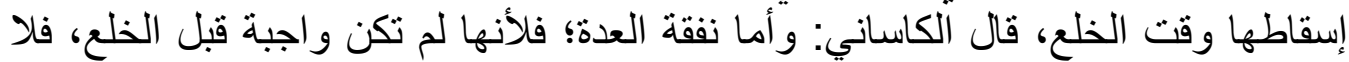

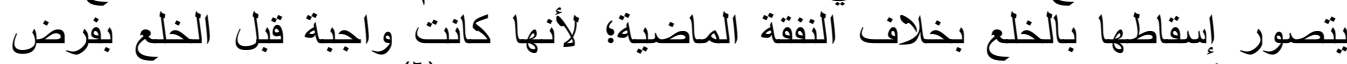

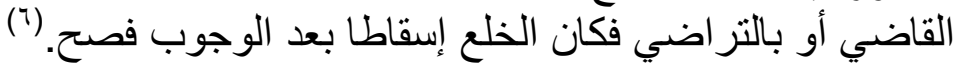

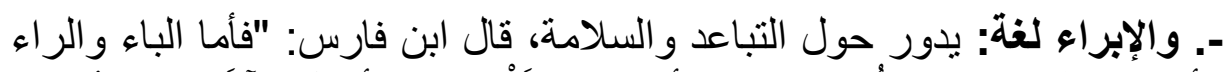

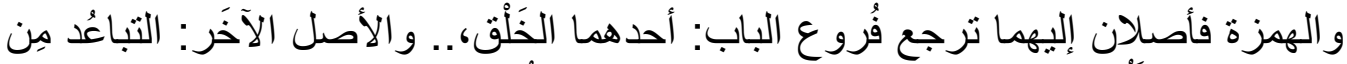

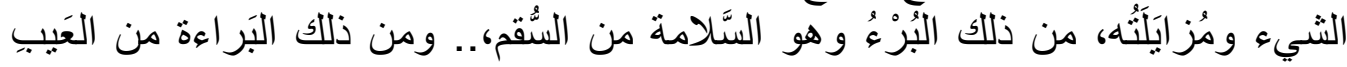

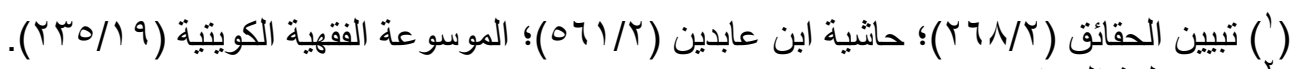

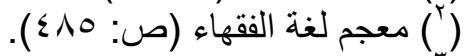

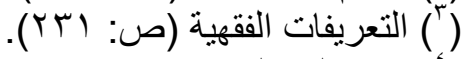

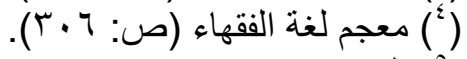

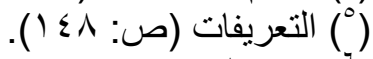

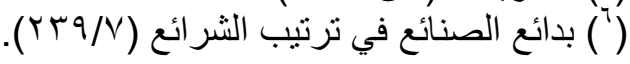




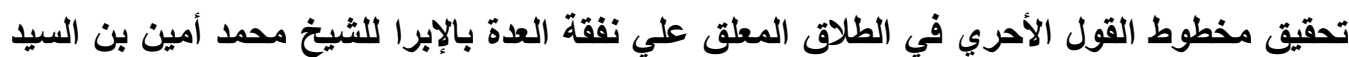

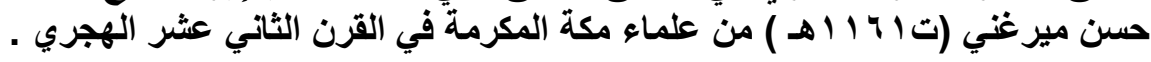

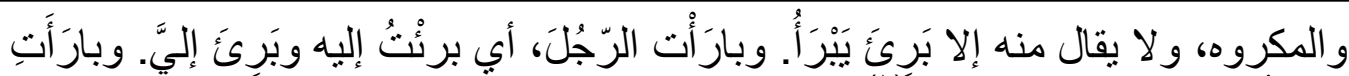

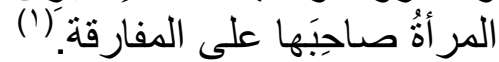

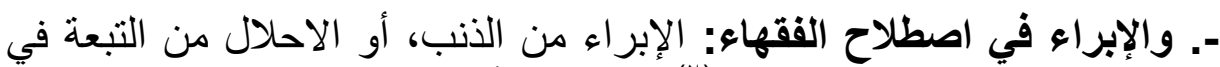

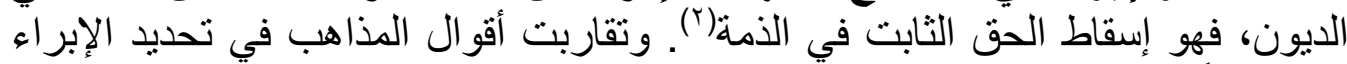

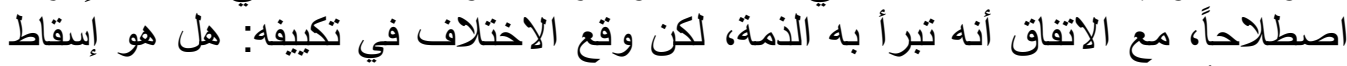

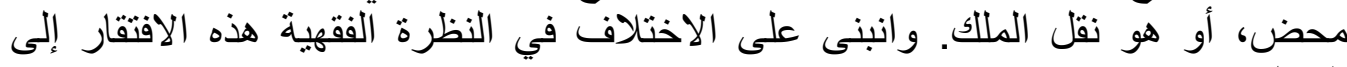
القبول و عدمه.

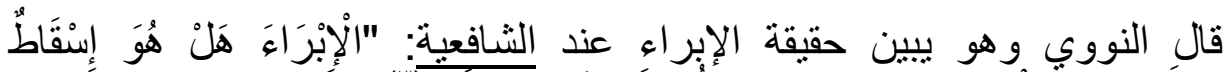

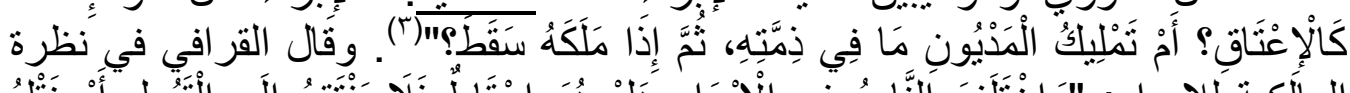

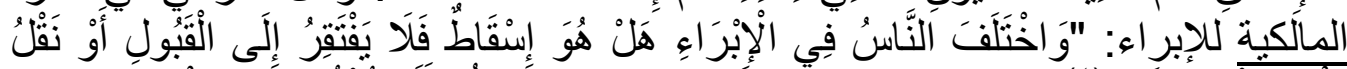

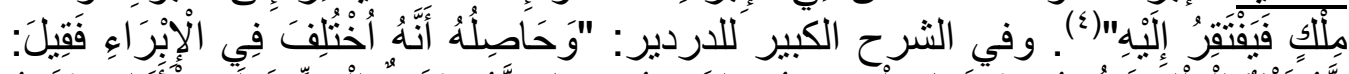

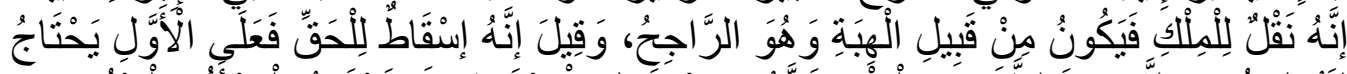

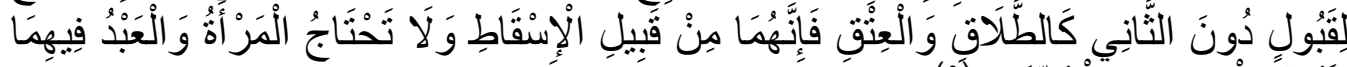

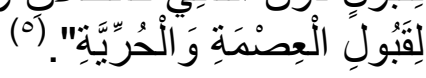

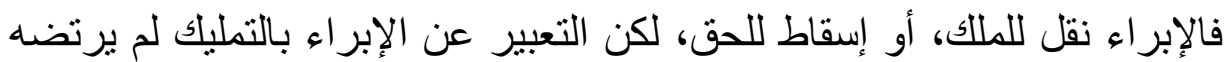

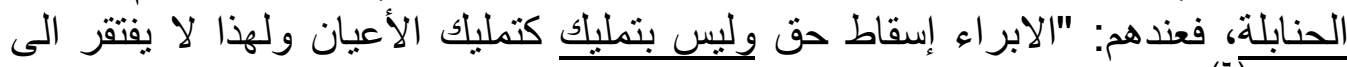

قبول".

و الحنفية عندهم الإبراء هو إسقاط الحق وليس التمليك، لكن لهم اهتمام بتقسيم

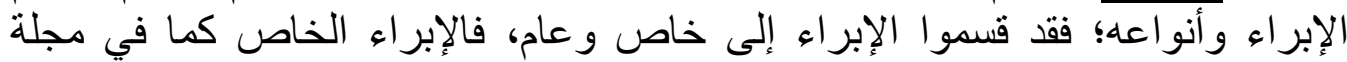

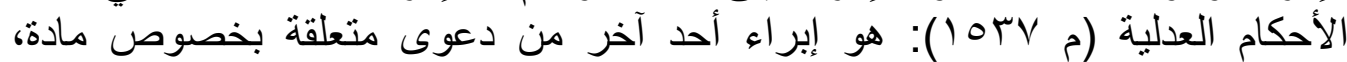

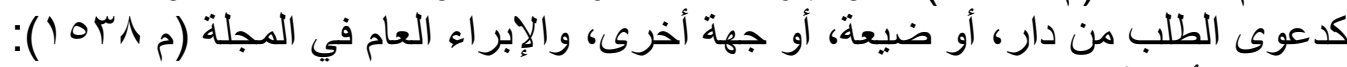

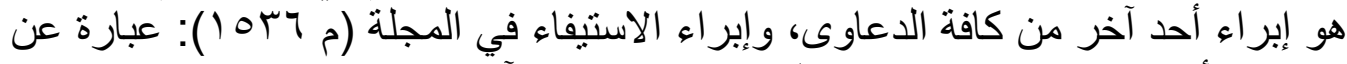

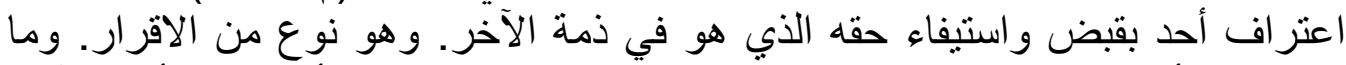

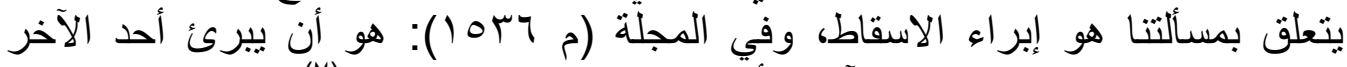

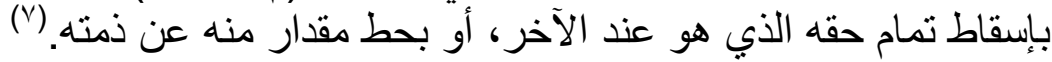

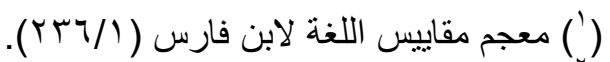

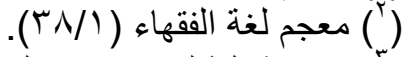

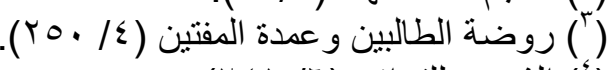

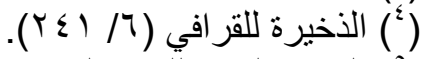

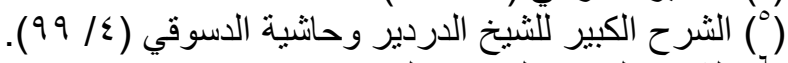

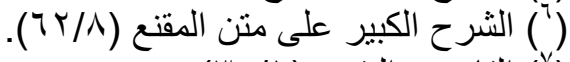

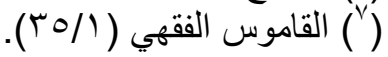


مجلة كلية الثريعة والقانون بتفهنا الأشراف ـ دقهلية العدد الثالث و العشرون لسنة إب ـ بم الجزء الثاني

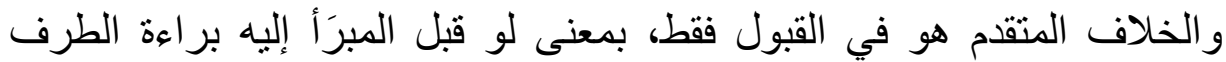

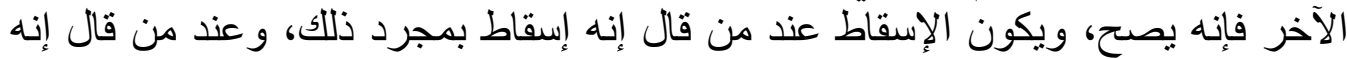

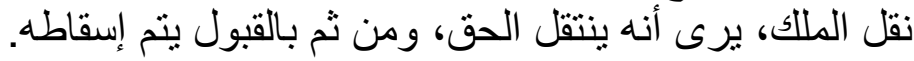

\section{*. المسألة الفقهية التي تعالجها الفتوى: برى ومن}

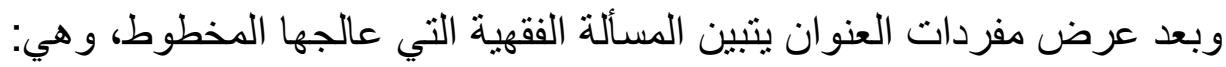

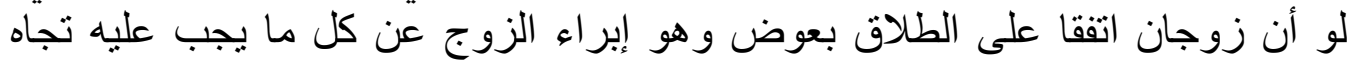

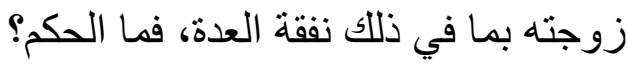

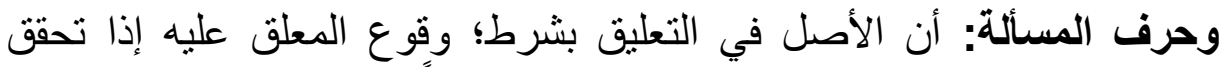

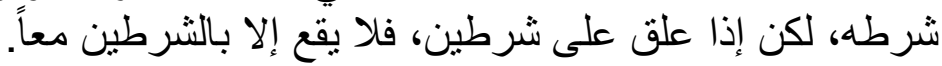

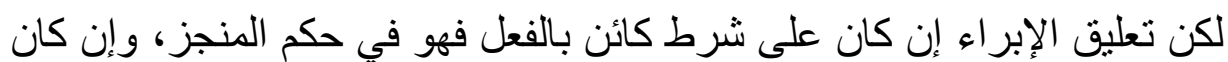

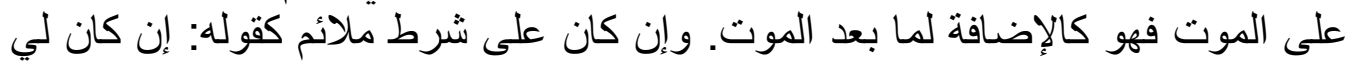

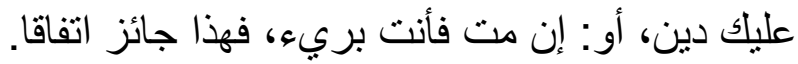

وأما التعليق على شرط من غير ما سبق فللفقهاء في حكم الإبراء المعلق عليه آراء

أحدها: عدم الجواز ولو كان الثرط متعارفا عليه. وهذا مذهب التهاب الحنفية

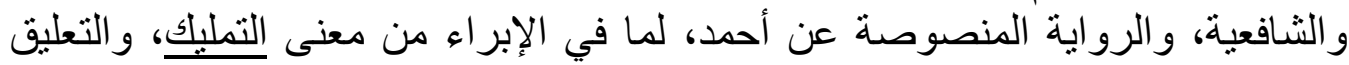
مشروع في الإسقاطات المحضة لا في التمليكات، فإنها لا تقبل التهن التعليق.

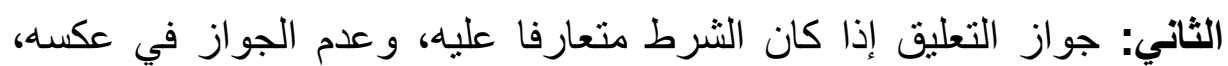
وهو رأي لبعض الحنفية.

الثالث: جواز التعليق مطلقا، وهو مذهب المالكية ورواية عن أحمد، وذلك لما

$$
\begin{aligned}
& \text { في الإبراء من معنى الإسقاط. (') } \\
& \text { وهو ما تقدم بحثه في تكييف الإبر اء. }
\end{aligned}
$$

وفي مسألة وقوع الطلاق بالإبراء من المهر ونفقة الإبرة العدة أقوال: - . عدم وقوع الطلاق المعلق بذلك، وبوقوع البر اءة من المهر فقط.

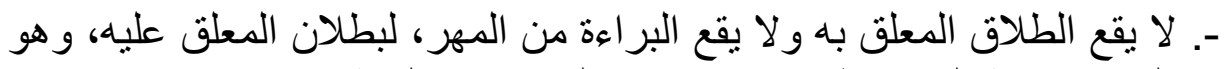
البر اءة من المهر، ونفقة العدة ببطلان جزئه وهو البر البر اهة من النفقة. -. وقوع الطلاق لصحة البراءة من المهر ونفقة العدة. 


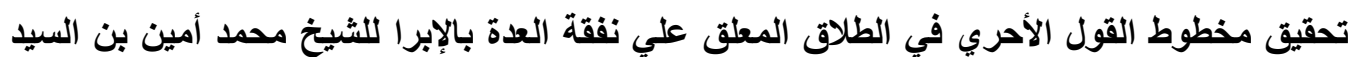

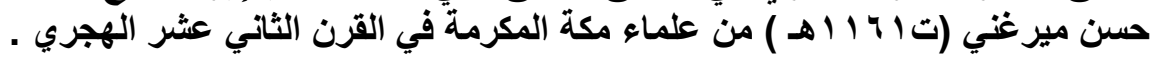

$$
\text { و الأخير هو ما رجحه صاحب المخطوط. }
$$

\section{ثالثاً: وصف المخطوط ومنهج التحقيق، ونماذج مصورة من المخطوط.}

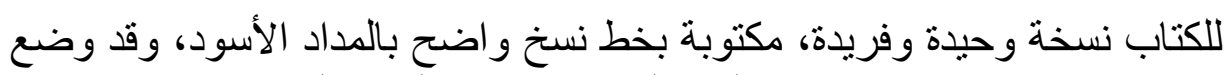

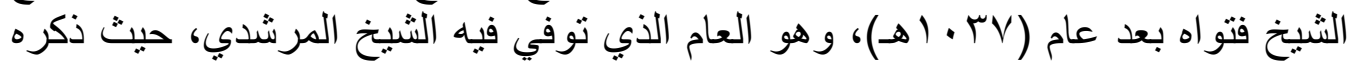

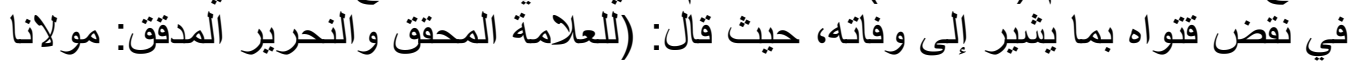

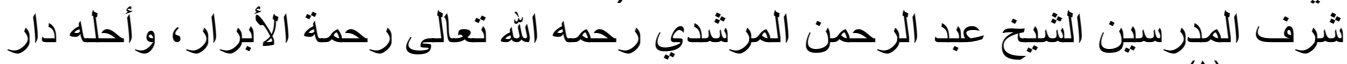

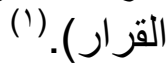

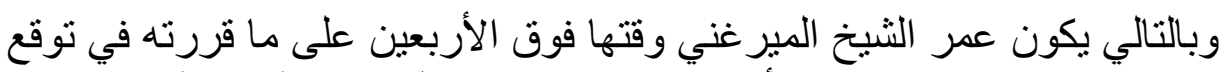

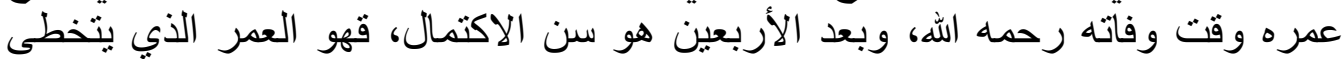

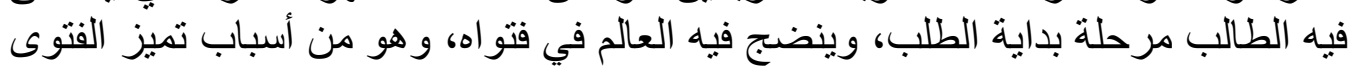
و الله أعلم.

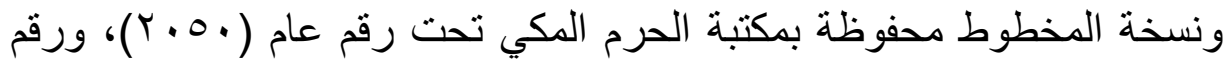

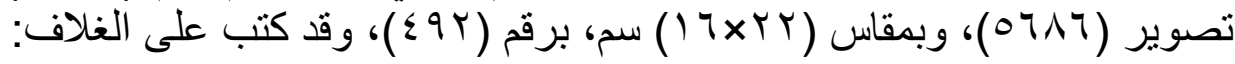

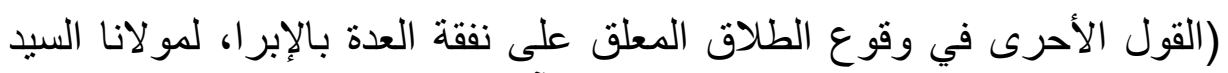

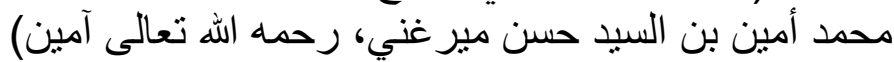

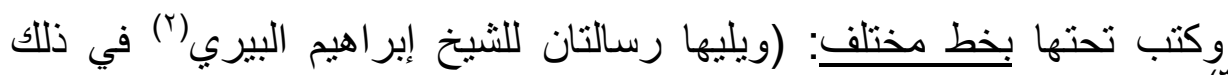

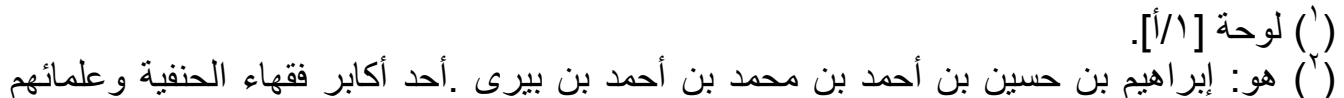

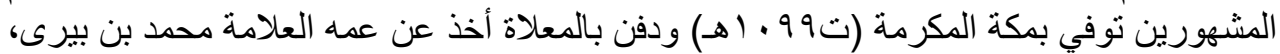

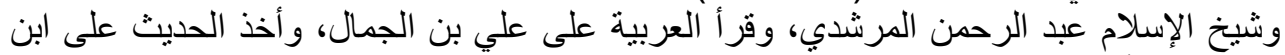

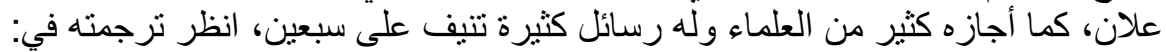
http://forum.makkawi.com/archive/index.php/t-75984.html.

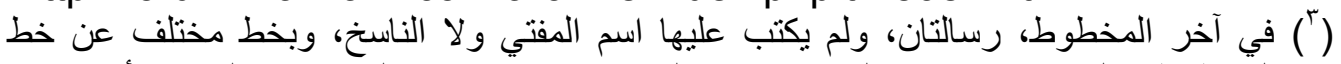

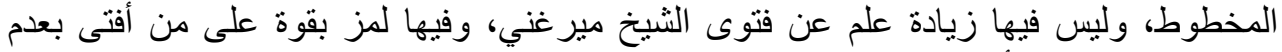

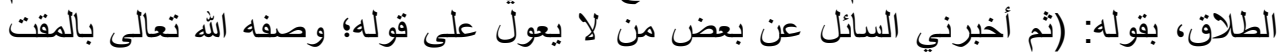
و النظم في العلماء)، ولا يظن بالبيري أنه يتكلم هكذا في شيخه المرشدي، فالله أعلم. 


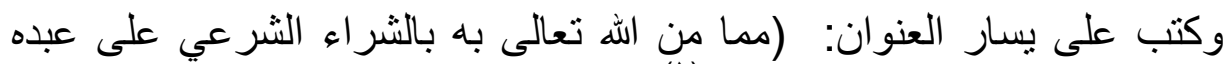

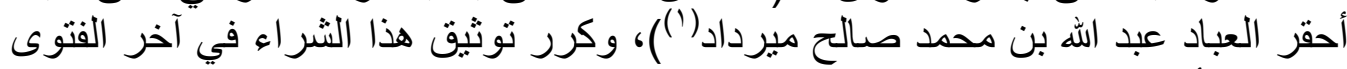

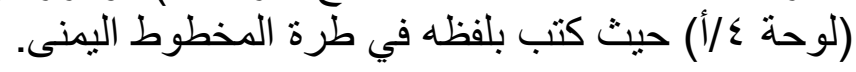

و المخطوط عليه ترقيم حديث باللون الأزرق لكل صفحة وقد اعتمدت في التوثيق على اللوحات، وليس على الصفحات. ومن الواضح أن المخطوط نم ترميمه بلصف أوراقه البالية على أوراق حديثة، استطاعت أن تبقي المخطوط في حالة جيدة.

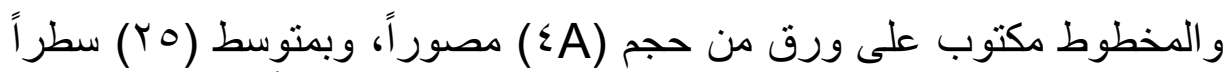

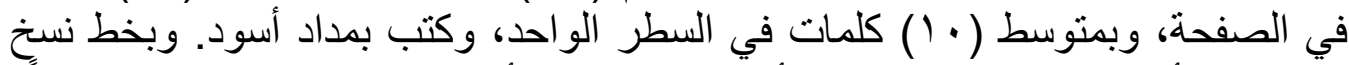

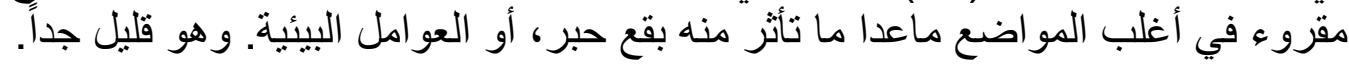
وكتب الناسخ اسمه أول المخطط على الغلاف: حيث كتب في يسار الصنار الصفحة

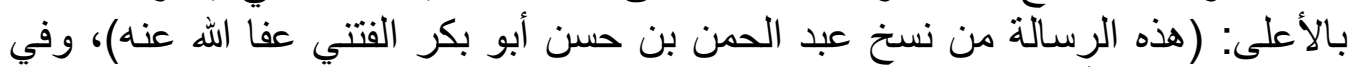

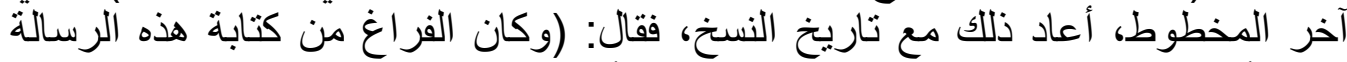

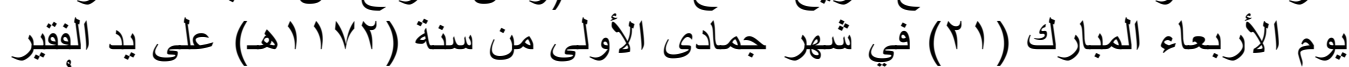

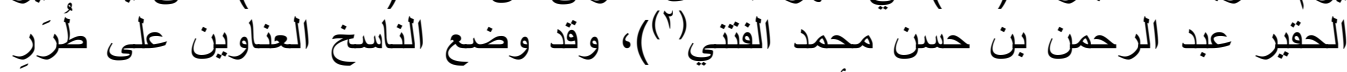

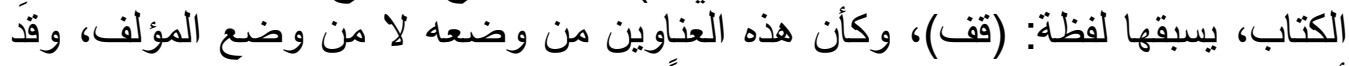

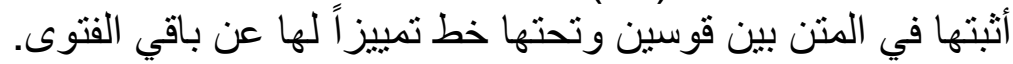

\section{- منهج المؤلف في فتواه:}

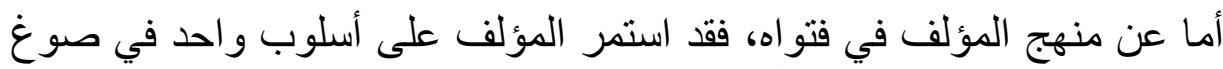

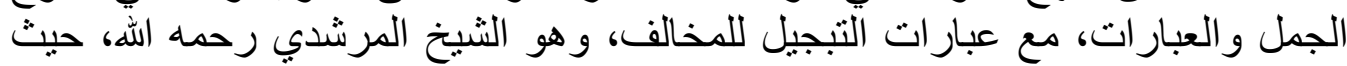

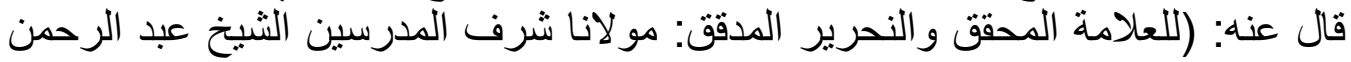

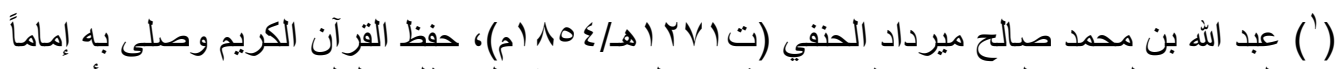

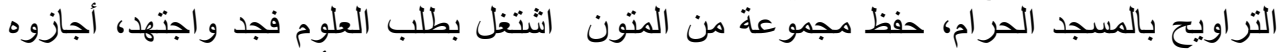

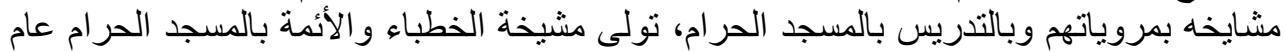

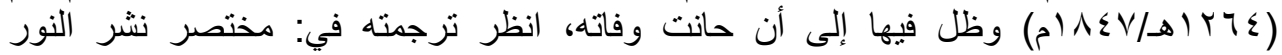

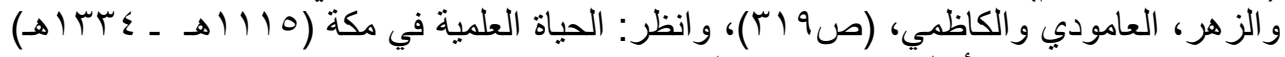

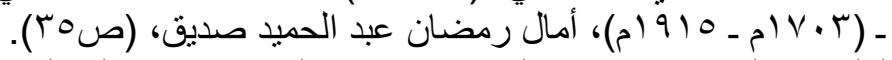

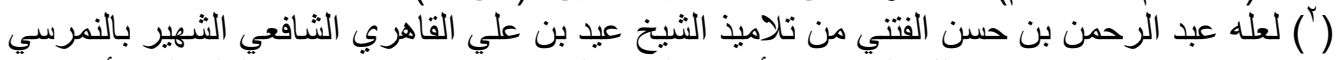

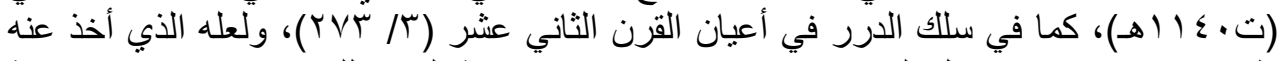

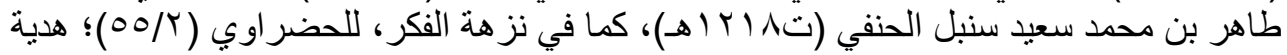

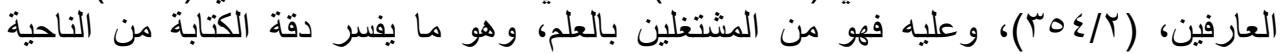


تحقيق مخطوط القول الأحري في الطلاق المعلق علي نفقة العدة بالإبرا للشيخ محمد أمين بن السيد

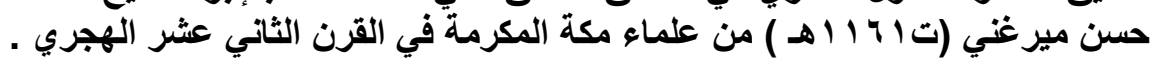

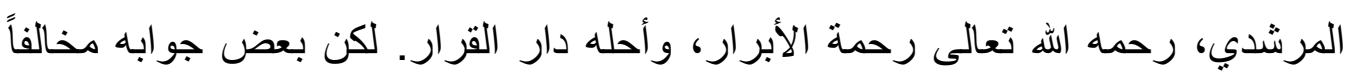

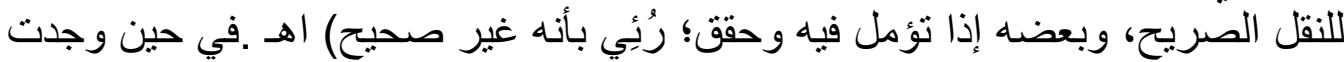

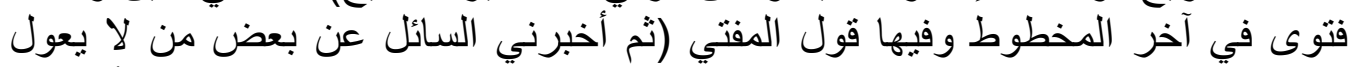

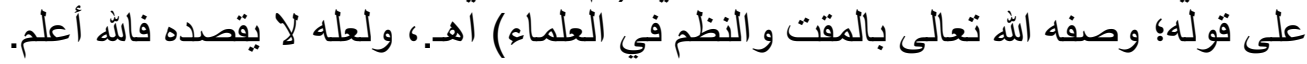

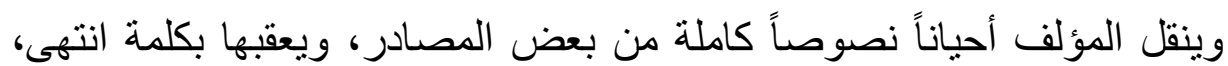

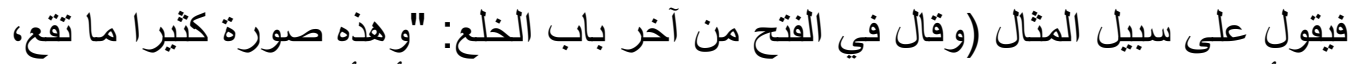

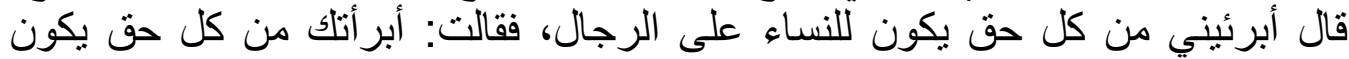

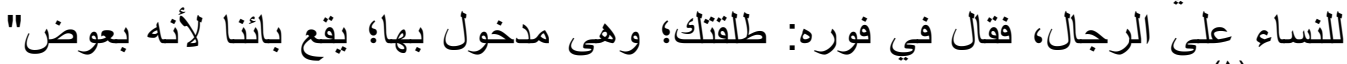
(') (انتهى.

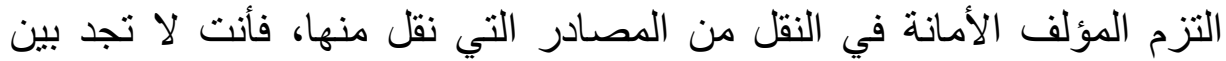

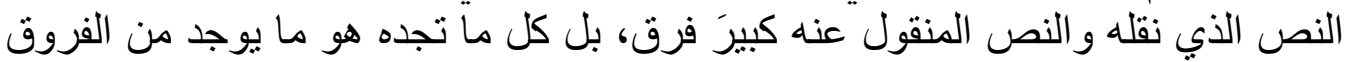

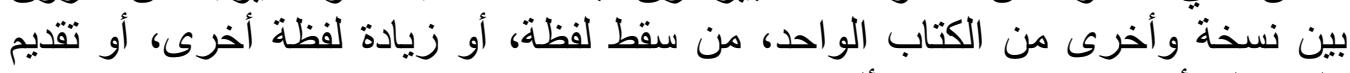
كلمة على أخرى، و هذا شيء من مألوف. لئ.

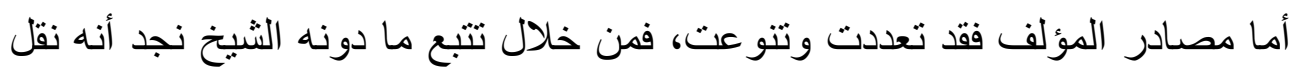

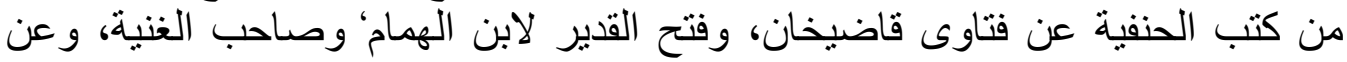

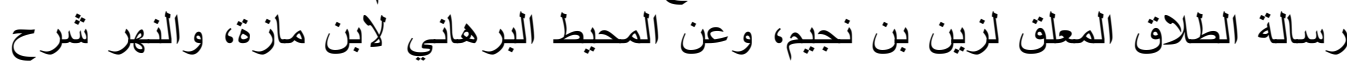

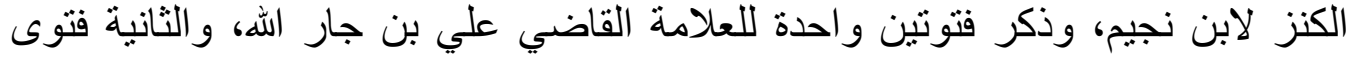

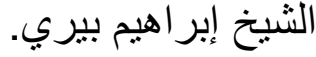

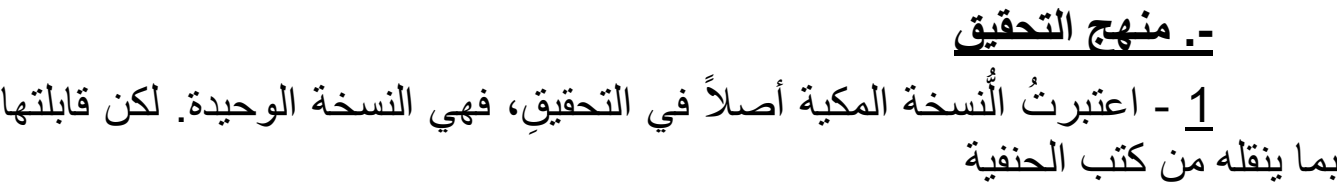

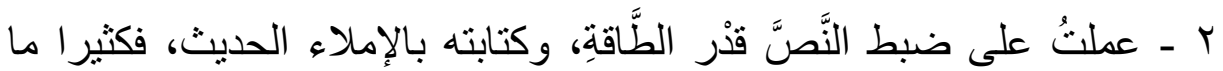

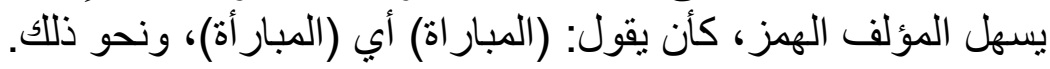

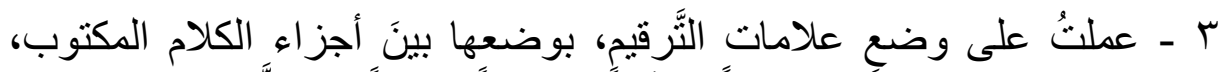

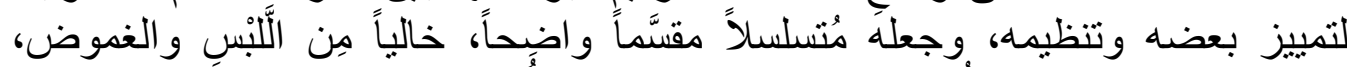

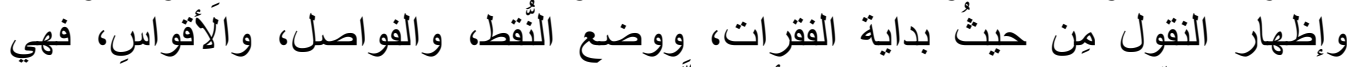

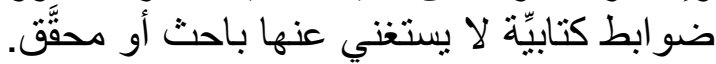


مجلة كلية الشريعة والقانون بتفهنا الأشراف ـ دقهلية العدد الثالث والعشرون لسنة اب ـ ب م الجزء الثاني

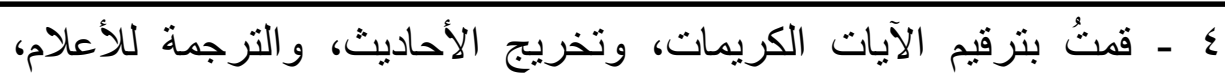

وتوضيح الغريب، وحيث قمت في الدراسة بشرح مفردات العنوان بإسهاب، فقد استغنيت

بذلك عن بيان غريبه في موضعه من المخطوط.

0 - قمتُ بعزو النُّصوص، وذلك بالرَّجوع إلى المصادر التي اقتبس منها

المؤلف من المطبوع.

7 - قمت بوضع رقم نهاية الورقة داخل النص وبين معكوفنين. 
تحقيق مخطوط القول الأحري في الطلاق المعلق علي نفقة العدة بالإبرا للشيخ محمد أمين بن السيد الثيا

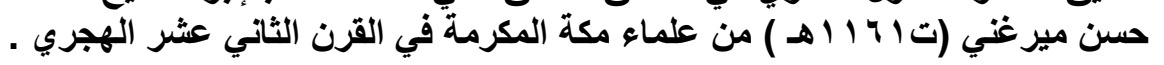

ـ- نماذج مصورة من المخطوط:

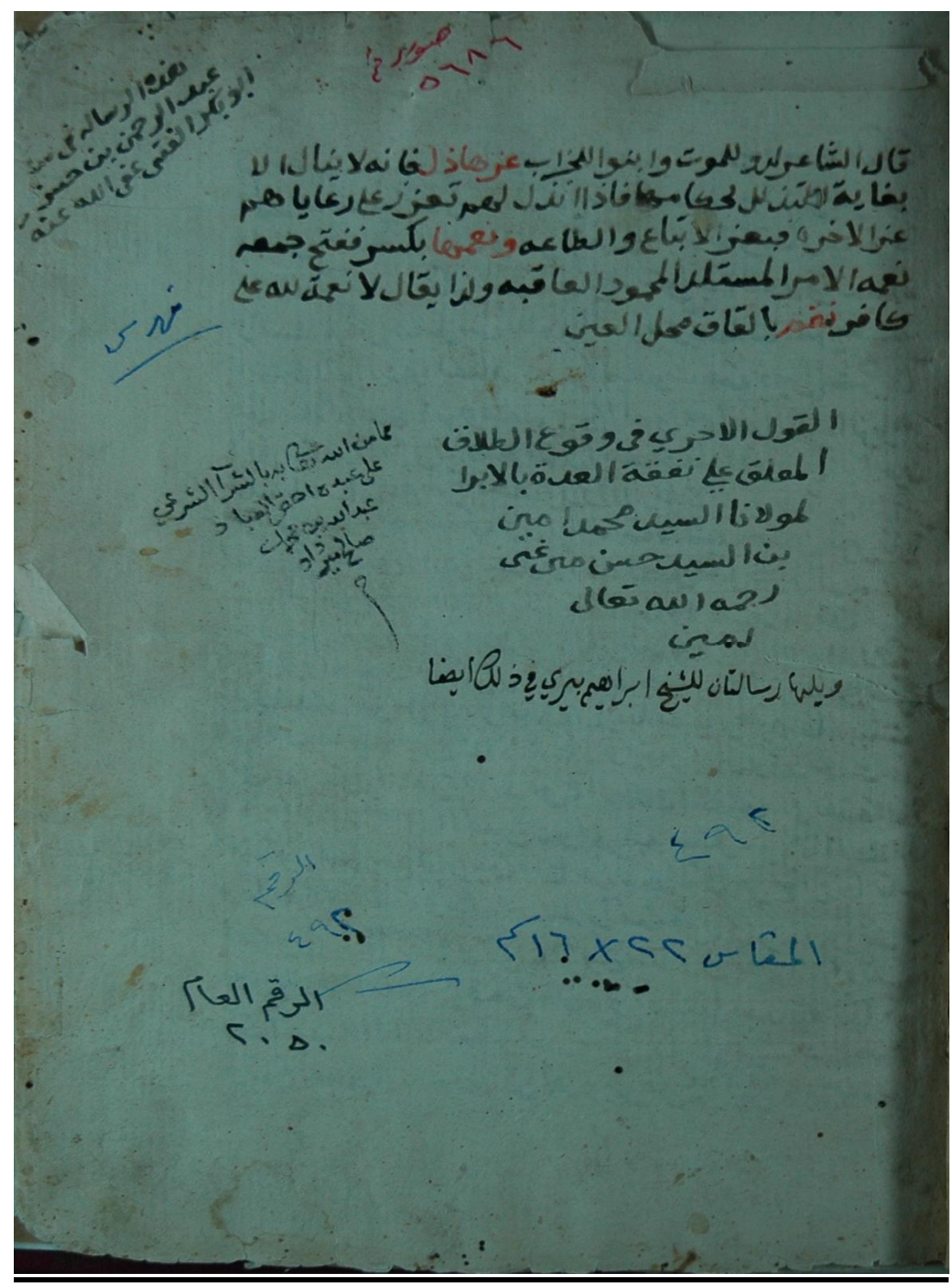

صفحة الغلاف للمخطوط

$-11 Y Y-$ 
مجلة كلية الثريعة والقانون بتفهنا الأشر اف ـ دقهلية العدد الثالث والعشرون لسنة اب ـ ب م الجزء الثاني

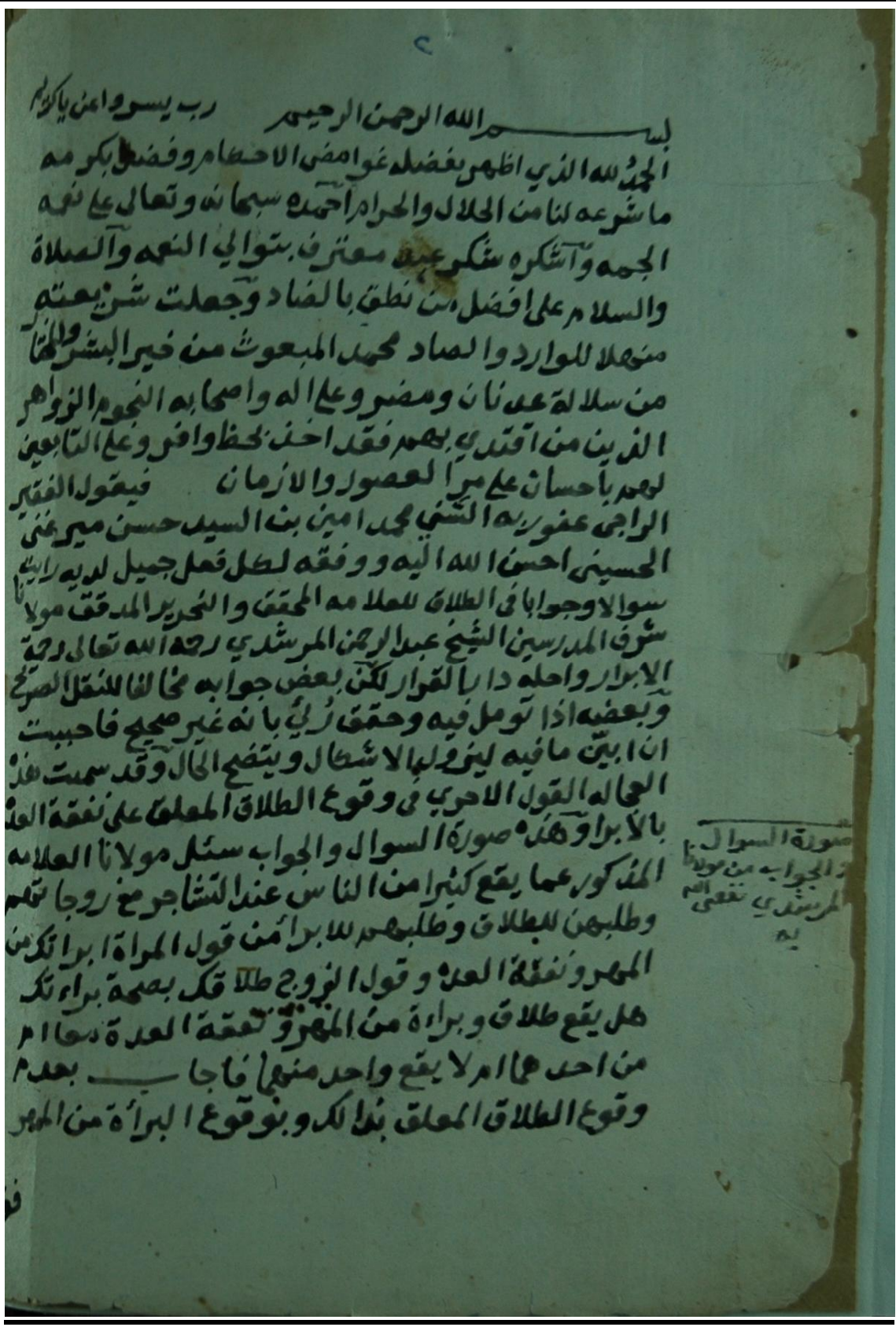

صورة بداية الفتوى 
تحقيق مخطوط القول الأحري في الطلاق المعلق علي نفقة العدة بالإبرا للشيخ محمد أمين بن السيد الثيا

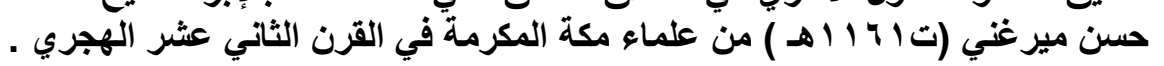

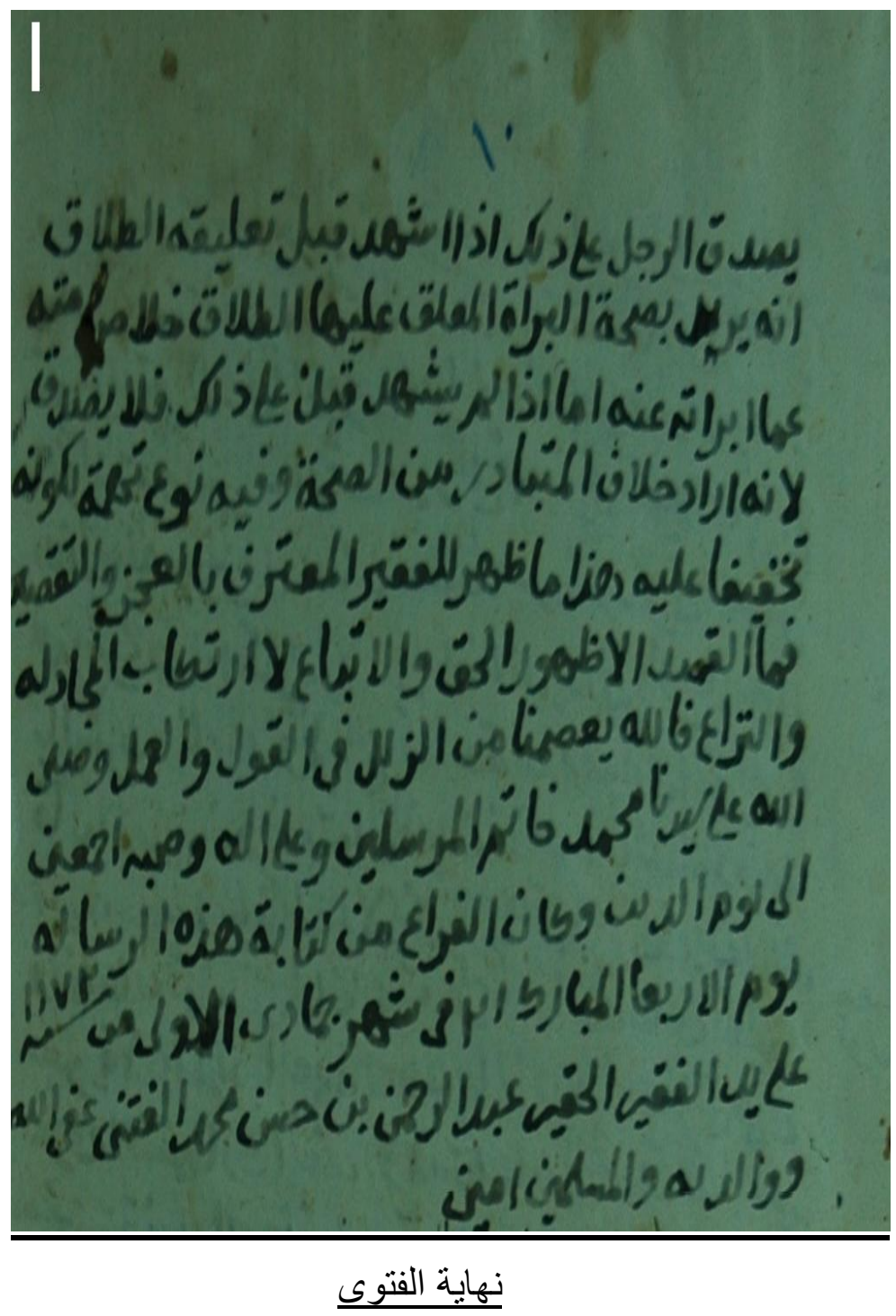




\section{هـ النص المقق}

$$
\text { بسم الله الرحمن الرحيم (رب يسر وأعن يا كريم). }
$$

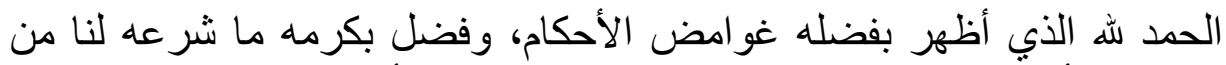

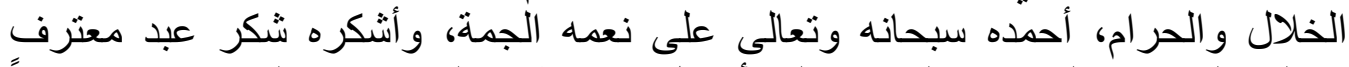

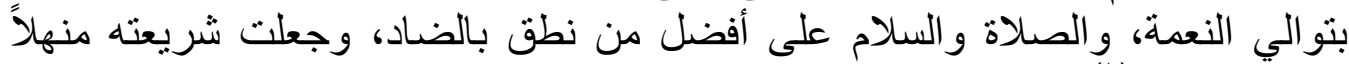

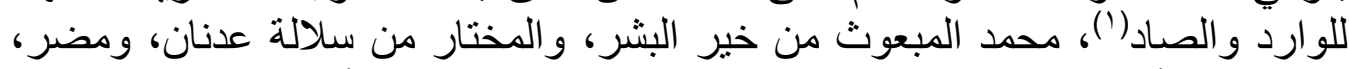

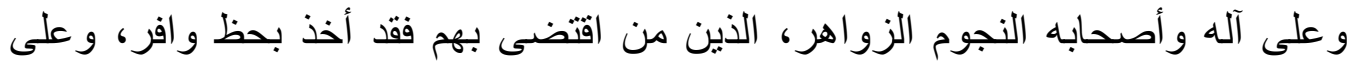

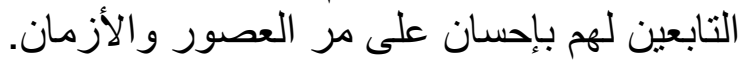

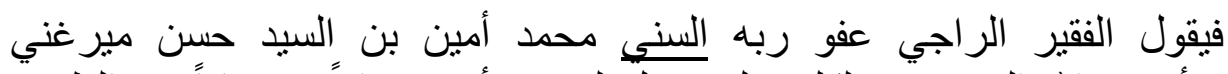

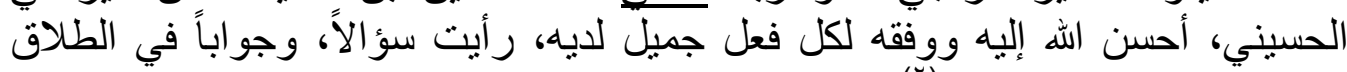

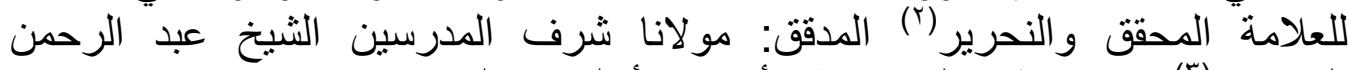

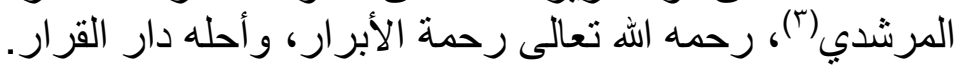

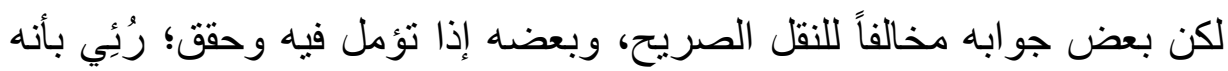

غير صحيح.

فأحبيث أن أبين ما فيه ليزول بالإشكال، ويتضح الحال.

وقد سميت هذه العجالة: "القول الأحرى في وقوع الطلاق المعلق على نفقة العدة بالإبر ا.")

(قف: صورة السؤال والجواب من مولانا المرشدي نفع الله بـ).(•)

وهذه صورة السؤال، و الجواب:

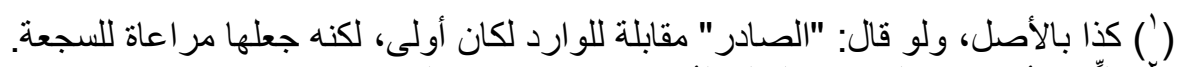

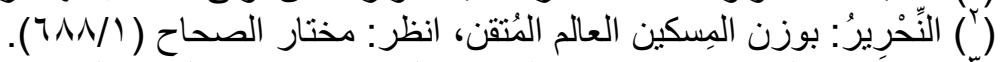

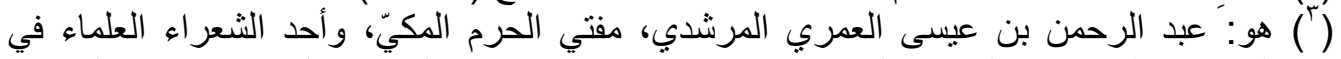

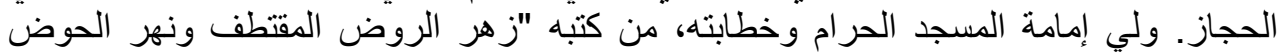

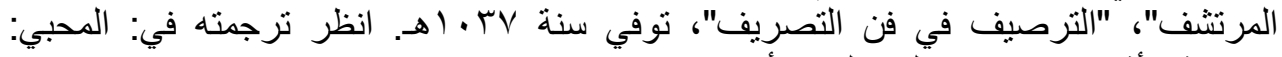

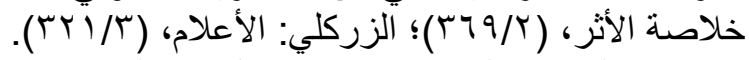

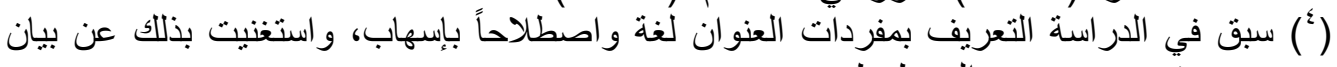

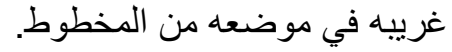

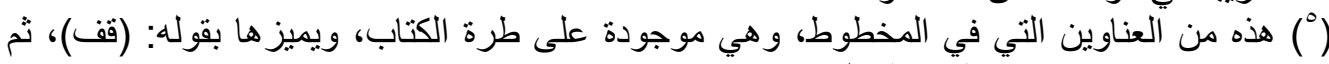

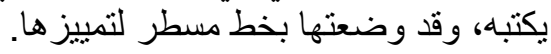




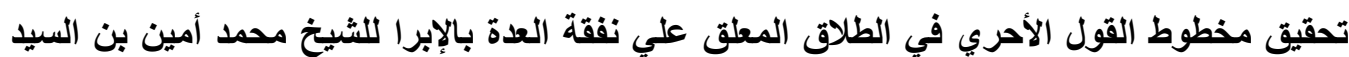

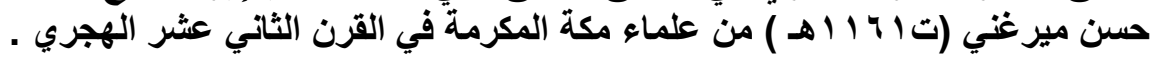

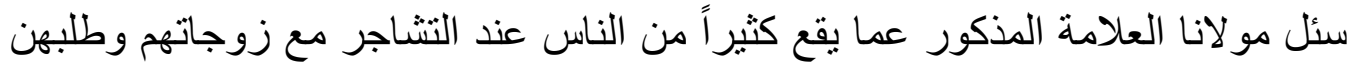

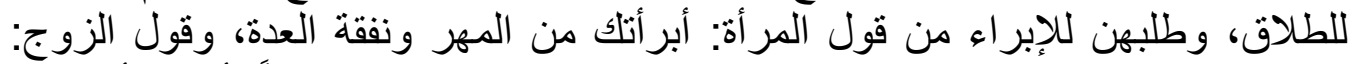

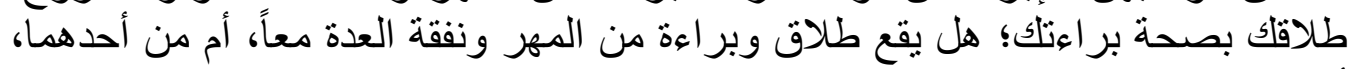

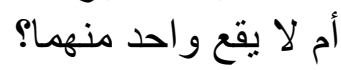

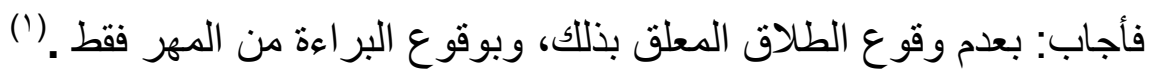
قال: ووافقني بعض حنفية العصر، وتوقف في ذلك بعض بعهم محتجاً بأن شيخنا

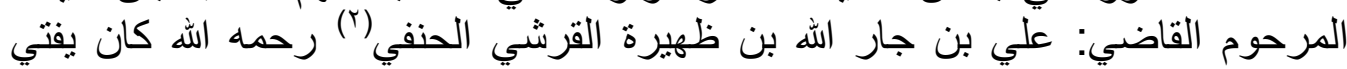
بوقوع الطلاق لصحة الَّر اعة من المهر ونفقة العدة.

\section{(القاضى على بن جار الله شيخ الشيخ عبد الرحمن المرشدي)}

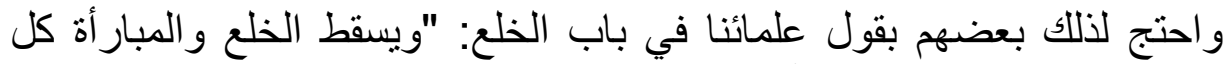

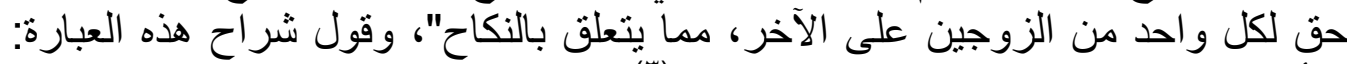

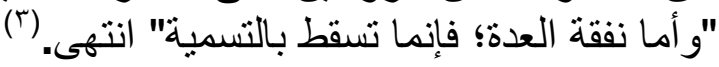

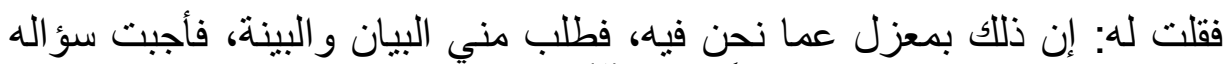

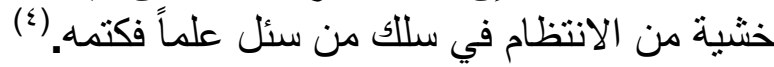
ومهدت قبل الخوض في ذلك مقدمة هي: إن المعلق بشيئين بنتفي بانتفاء أحدهما

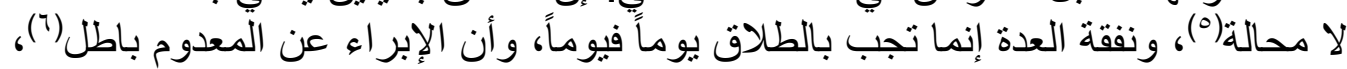

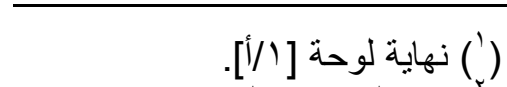

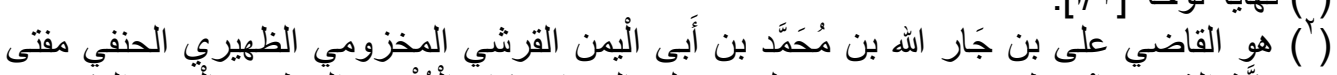

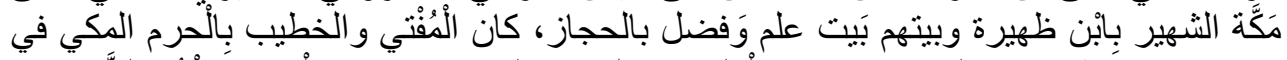

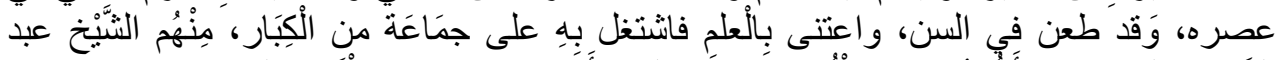

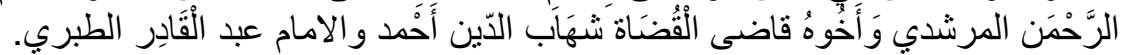

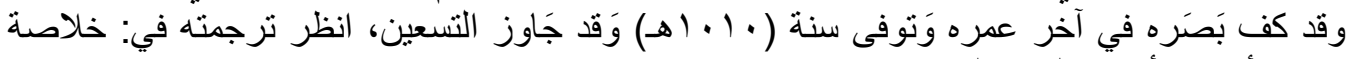

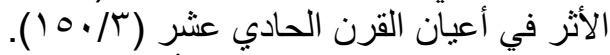

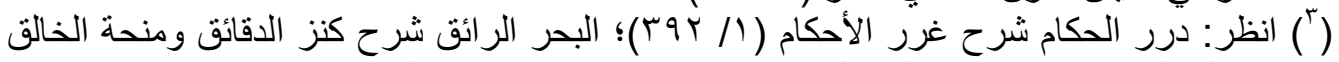

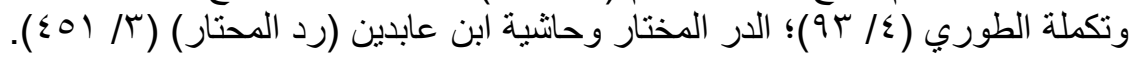

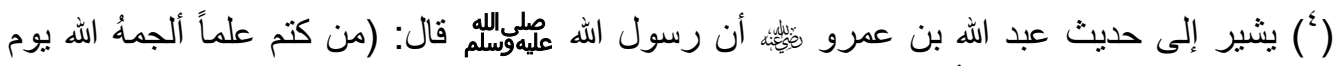

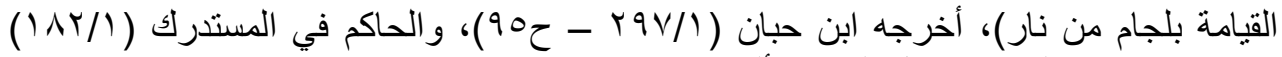

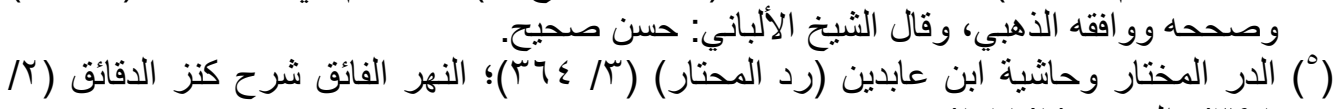


مجلة كلية الثريعة والقانون بتفهنا الأشر اف ـ دقهلية العدد الثالث والعشرون لسنة اب ـ بم الجزء الثاني

باطل(')، فالمعلق به كذلك؛ إذا تقرر هذا؛ فلا يقع الطلاق المعلق بصحة البراءة ونفقة العدة لانتفاء علته بانتفاء جزئه، و هو صحة البراءة عن نفقة العدة لأنها في حال التعليق

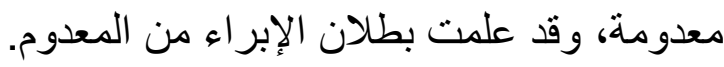

و لا اغترار بالعبارة المذكورة في باب الخلع، ولا بما قال شر احها، لأن المراد

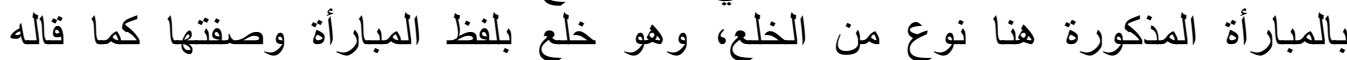

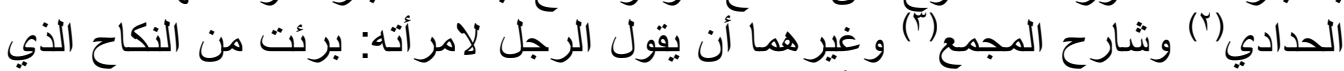

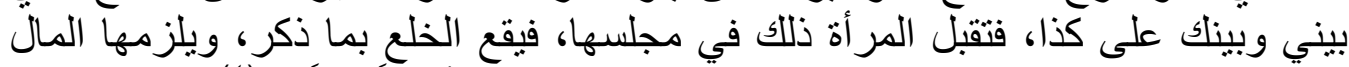

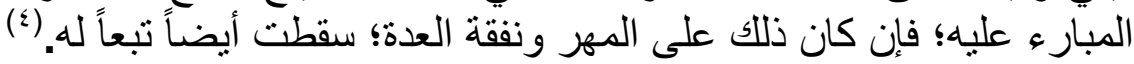
إذا علمت هذا؛ ظهر للك أن ما نحن فيه ليس من ذللك في شيء، و إنما هو تعليق

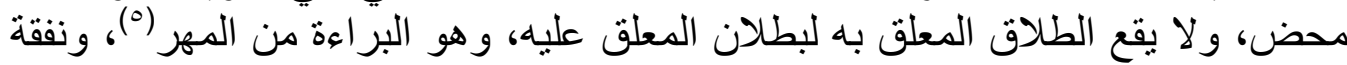

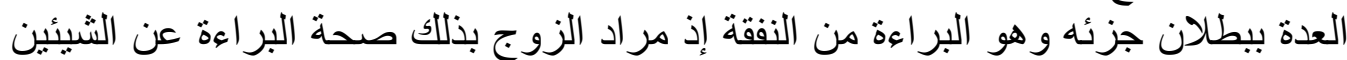

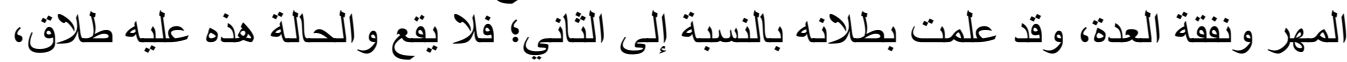

و الله أعلم.

و إنما أطلات الكلام في هذا المقام ليتضح به ما خفي على بعض الأفهام، ويظهر

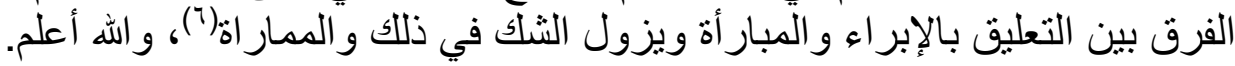
انتهى جواب العلامة المذكورة فأقول مستمداً من الله التوفيق. وهو خير المعين

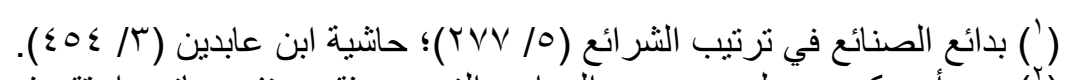

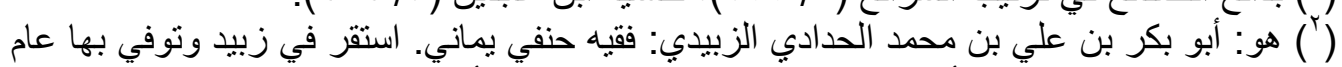

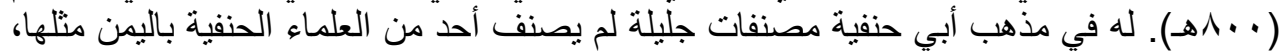

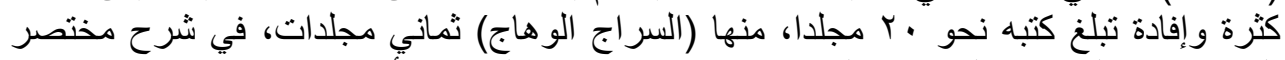

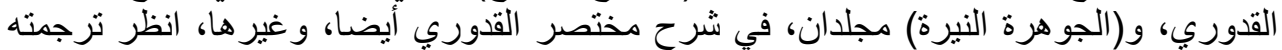

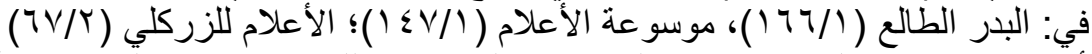

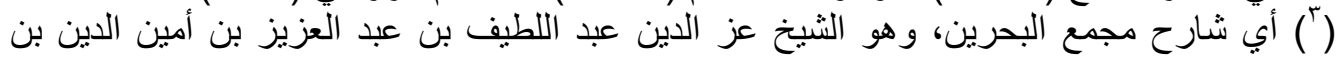

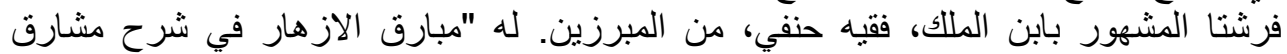

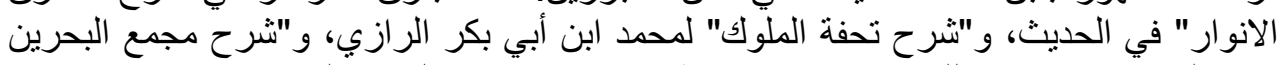

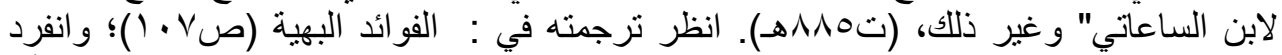

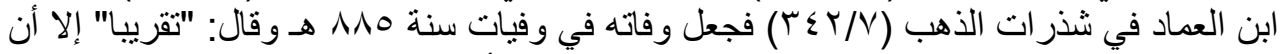

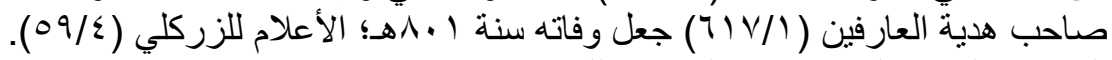

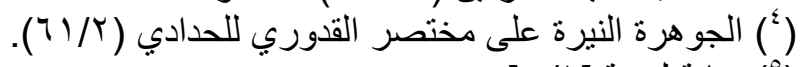

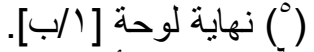

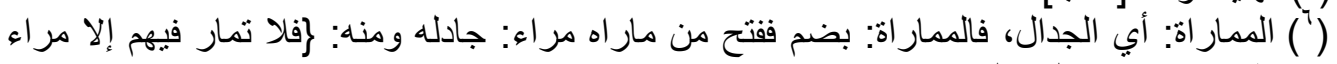

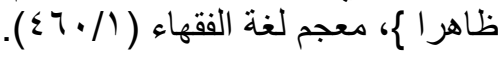




\section{(قف: تعقيب على كلام العلامة مولانا السيد أمين ونقول المذهب).}

أما ما ذكره المجيب من وقوع البر اءة من المهر و عم وقوع الطلاق؛ فهو مخالف

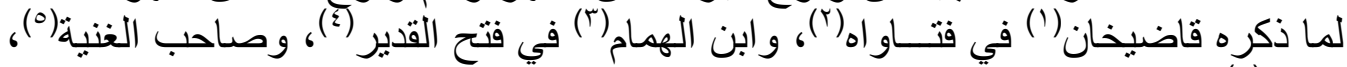

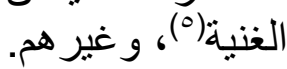

(') قاضيخان: هو حسن بن منصور بن محمود الأوزجيندي المشهور بقاضيخان، من كبار فقهاء

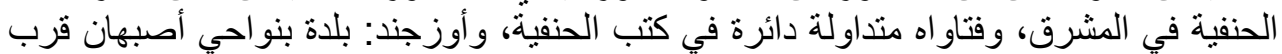

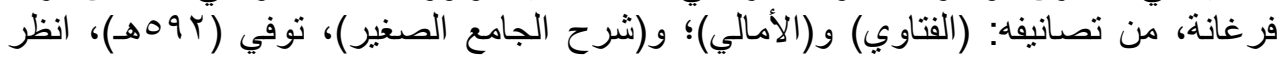

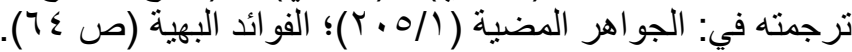

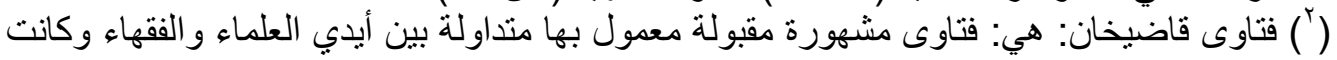

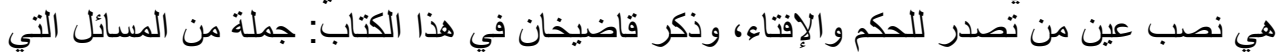

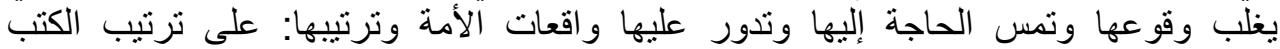

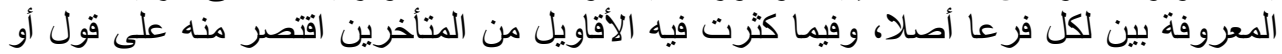

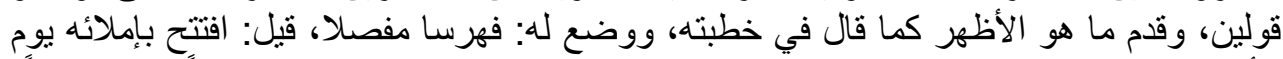

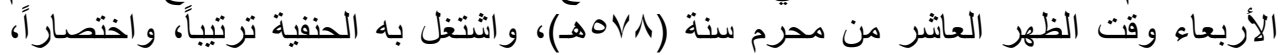

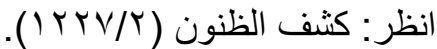

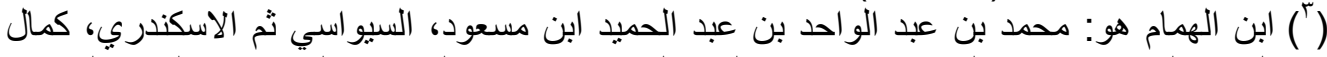

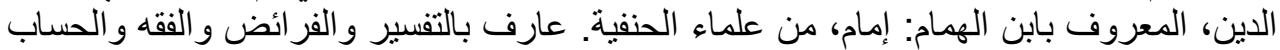

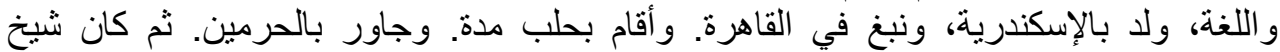

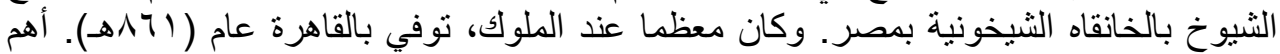

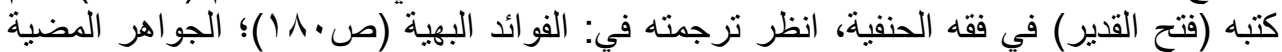

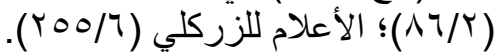

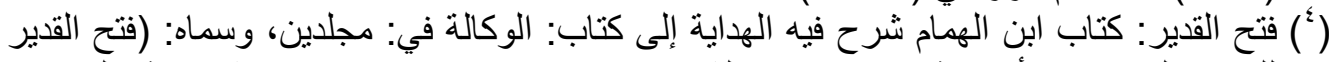

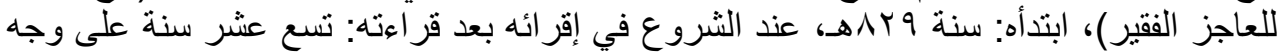

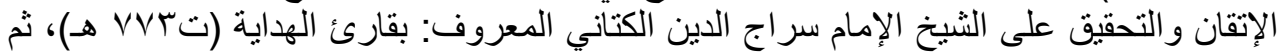

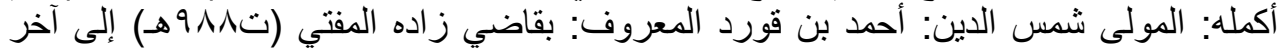

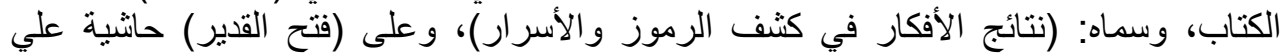

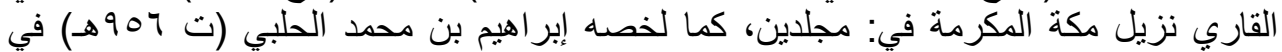

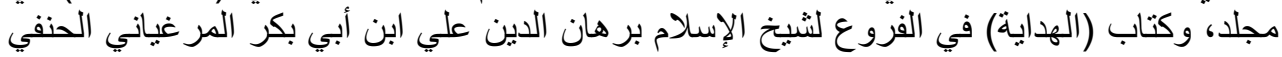

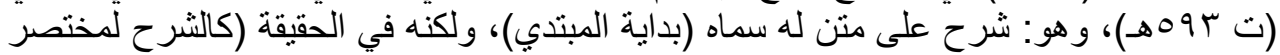

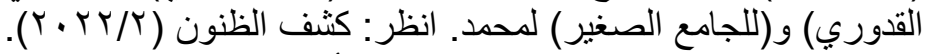

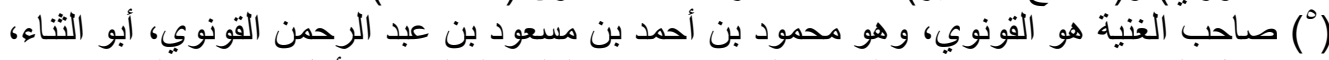

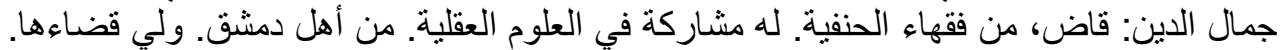

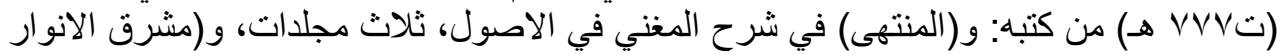

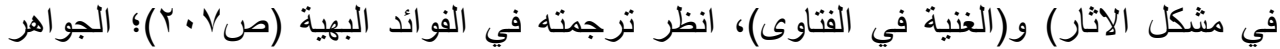

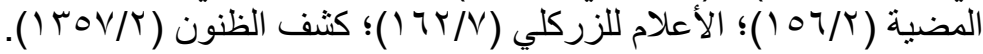




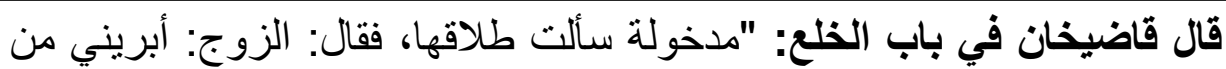

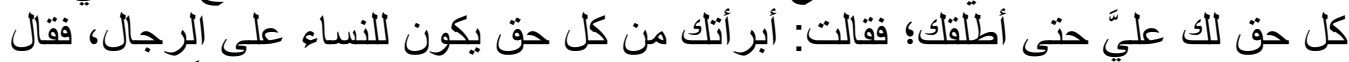

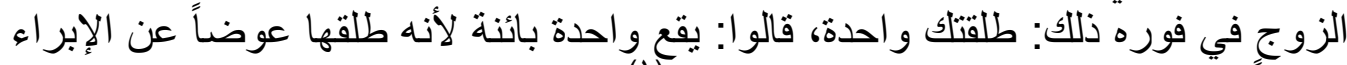

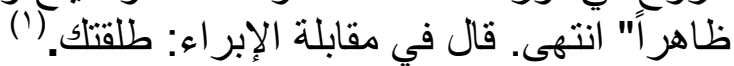

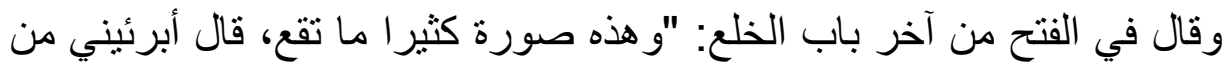

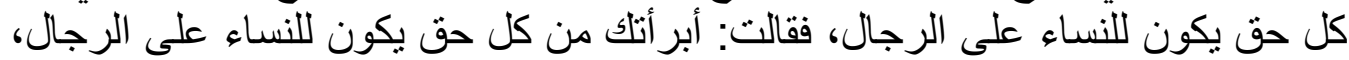

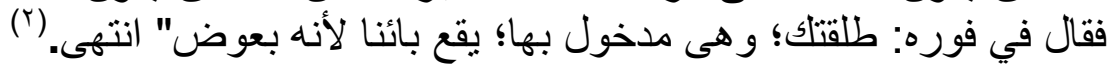

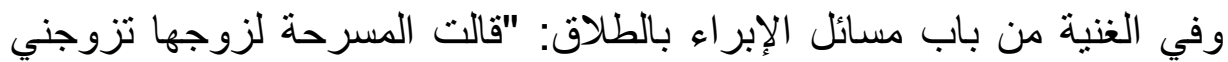

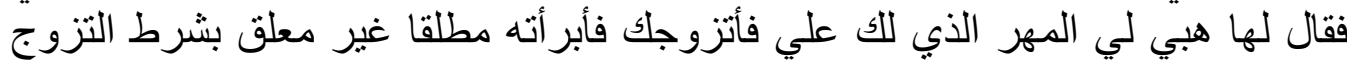

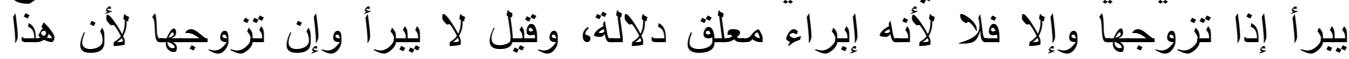

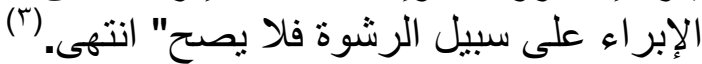

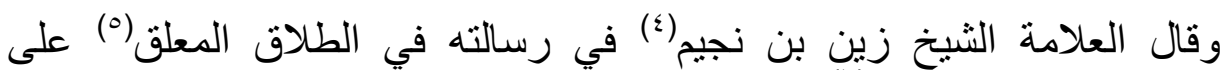

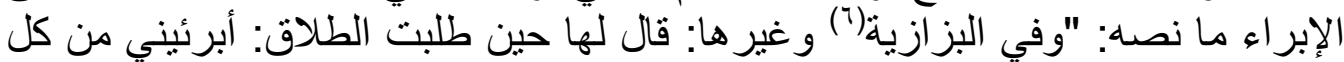

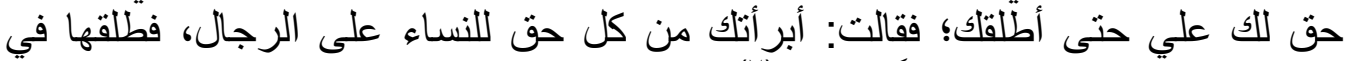

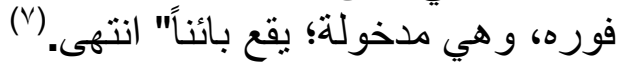
و علله في التجنيس(^) بأنه يقع بعوض، وهئ وهو الإبراء دلالة. انتهى. (')

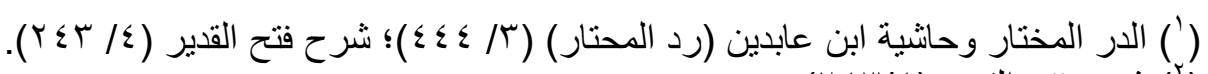

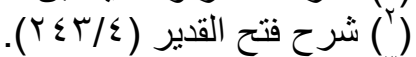

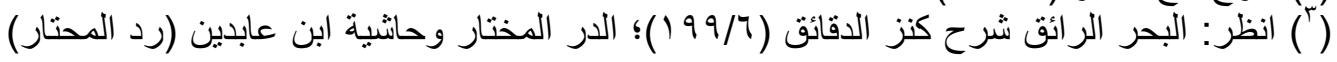

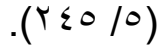
() (ابن نجيم: هو زين الدين بن إبراهيم بن إهن محمد، الثهير بابن نجيم: فقيه حنفي، من العلماء. مصري.

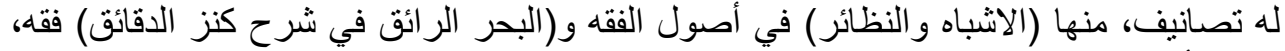

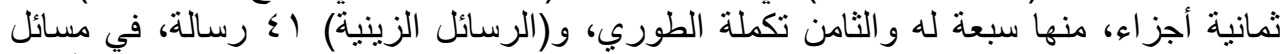

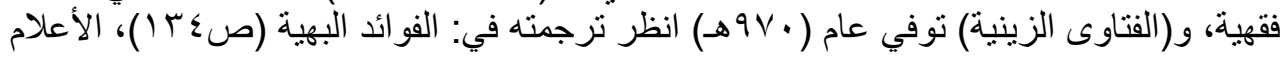

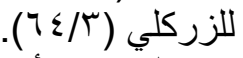

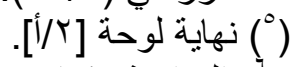

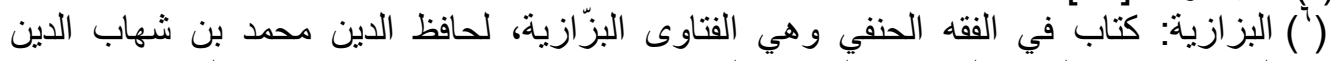

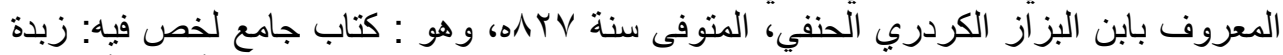

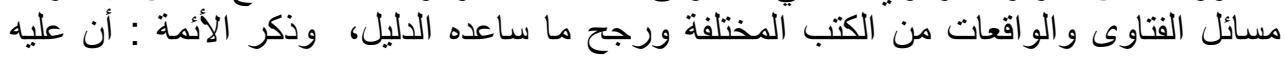

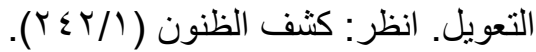

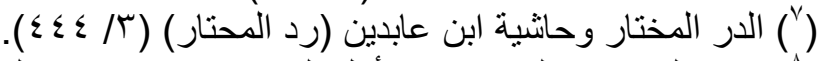

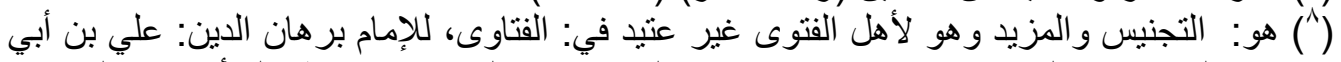

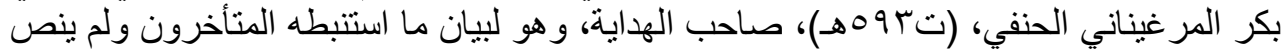

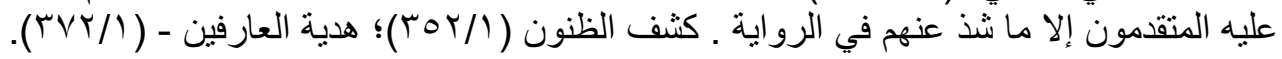


تحقيق مخطوط القول الأحري في الطلاق المعلق علي نفقة العدة بالإبرا للشيخ محمد أمين بن السيد

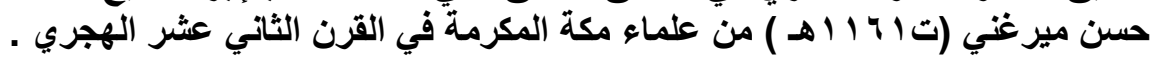

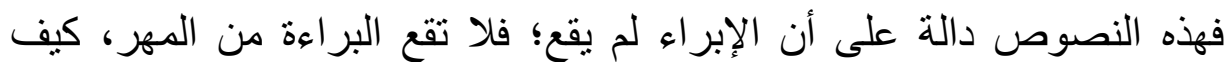

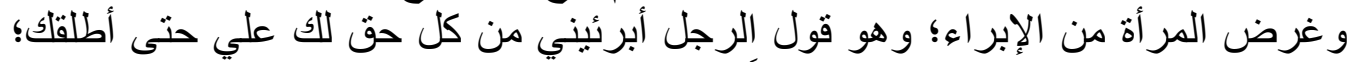

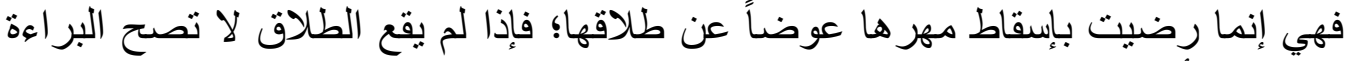
منه، و الله أعلم.

\section{(قف: على أن الإبراء عن النفقة وهو باطل إذا لم يكن في مقابلة شىع).}

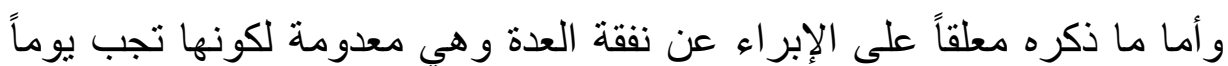

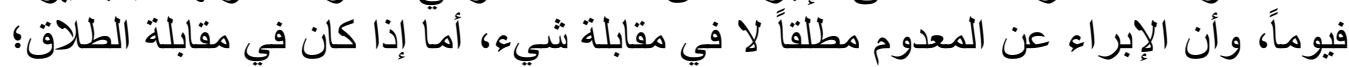

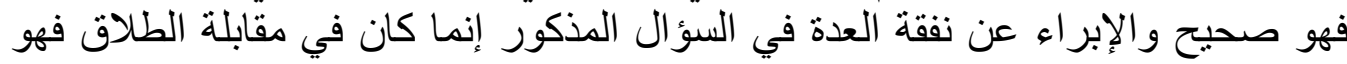

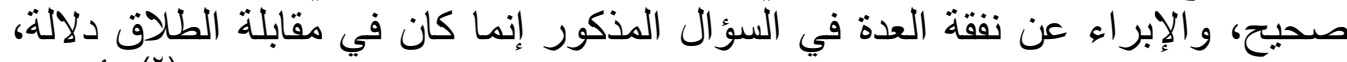

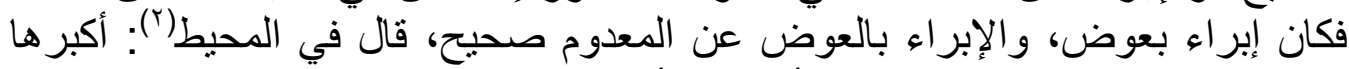

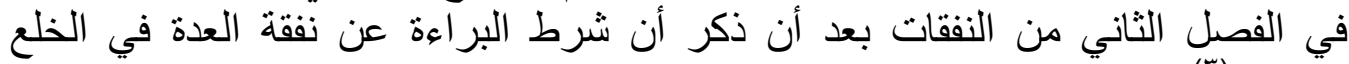

صحيح. (r) (1) (1)

\section{(قف: شرط البراءة عن نفقة العدة صحيح):}

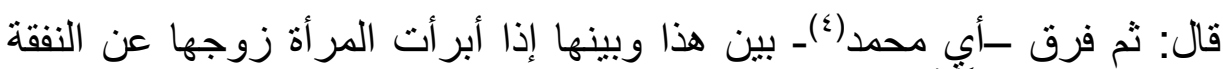

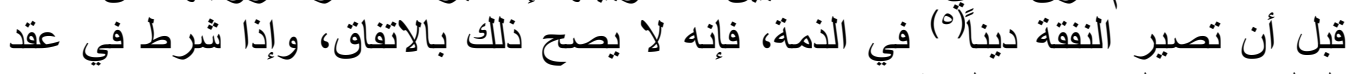
الخلع براءة الزوج عن النفقة صنح.

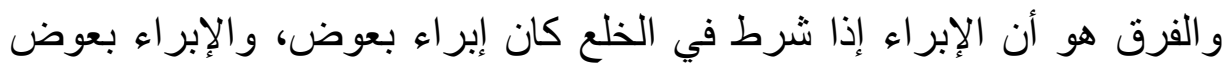

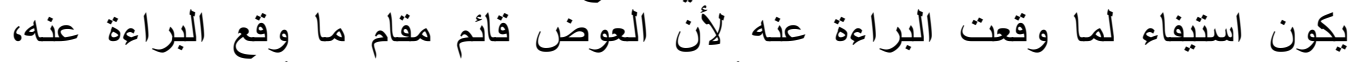

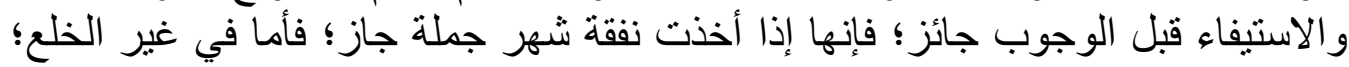

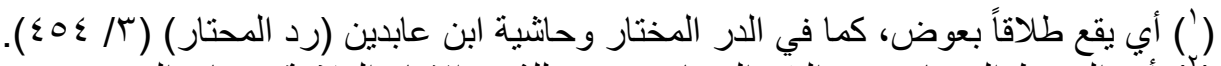

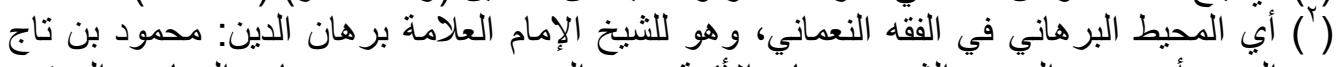

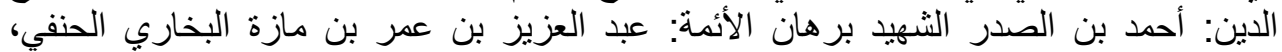

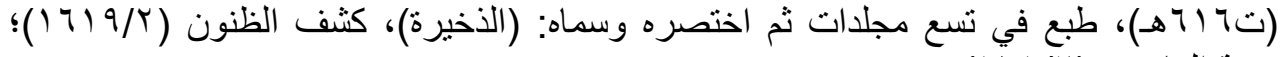
هدية العارفين (T) (17/7) (17).

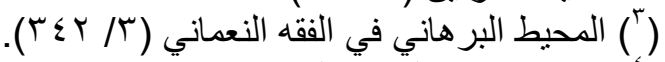

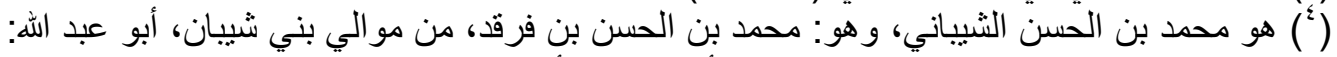

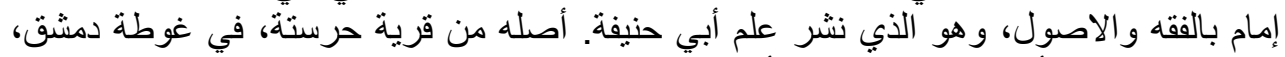

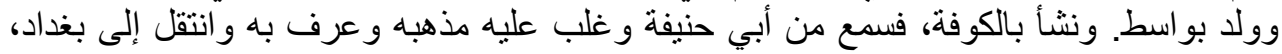

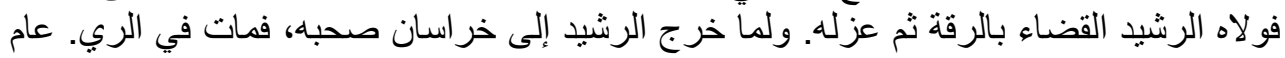

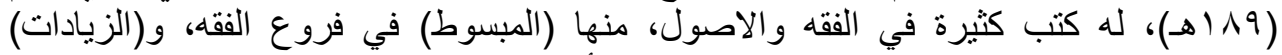

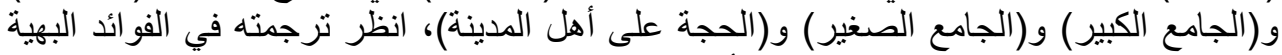

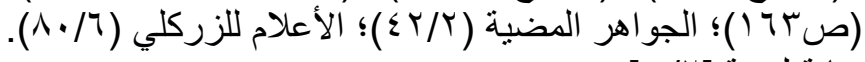


مجلة كلية الثريعة والقانون بتفهنا الأثراف ـ دقهلية العدد الثالث والعشرون لسنة إ ـ ب م الجزء الثاني

فالإبر اء إنما يحصل بغير عوض، فيكون إسقاطاً محضاً وإسقاط الثيء قبل الوجوب لا

يصح بالاتفاق. انتهى. (') بعلير

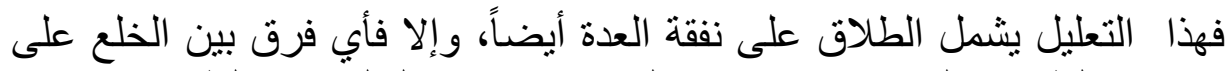

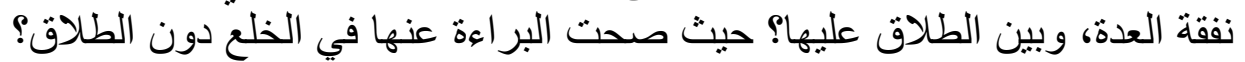

فإن نفقة العدة معدومة في الخلع عليها أيضاً.

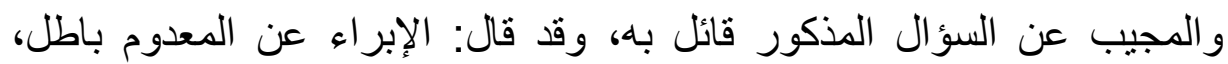

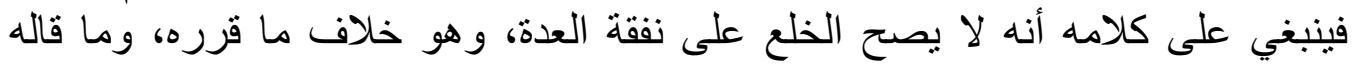

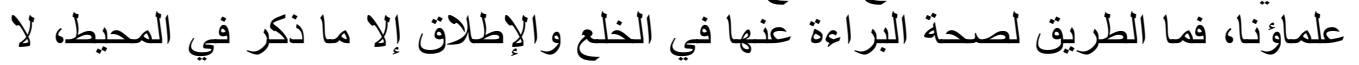

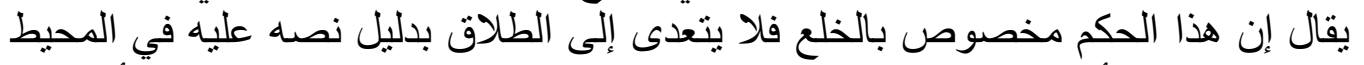
دون الطلاق، لأنا نقول: قوله في الفرق والإبراء بعوض بكأ يكون استيفاء ينادي أن حكم الطلاق كذلك.

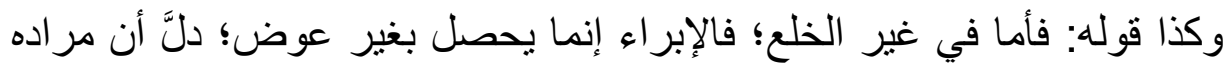

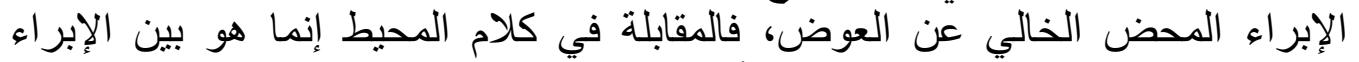

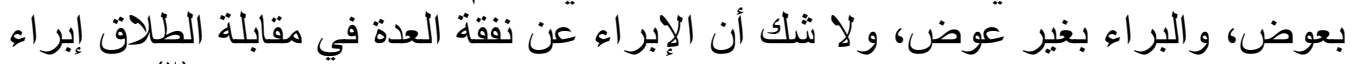

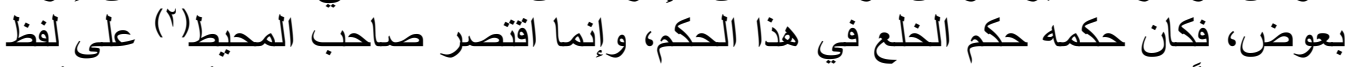

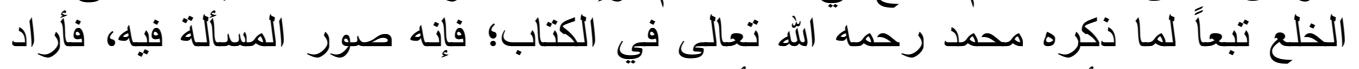

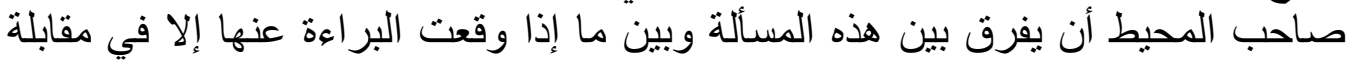
شيء حيث صحت البر اءة عنها في الأول، ولم تصح في الثاني؛ لا أن هذا الحكم مقتصر على لفظ الخلع فقط.

و هذا لا شك فيه ولا خفاء، ولذا قال قاضيخان في فتاواه في آخر باب الخاب الخلع:

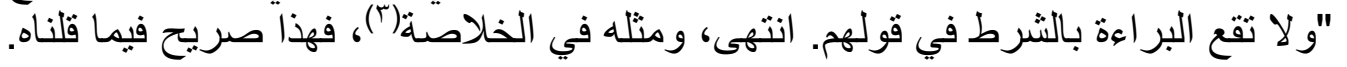

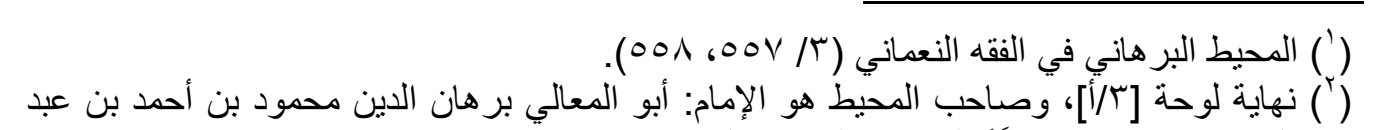

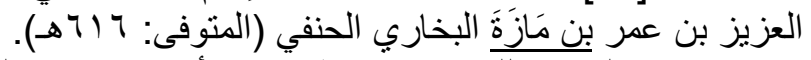

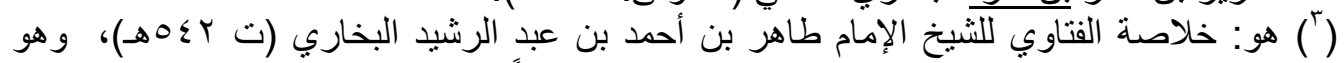

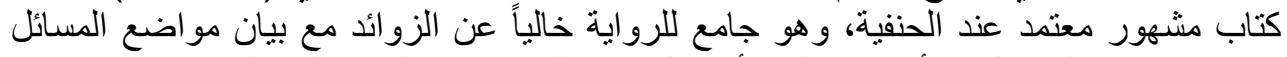

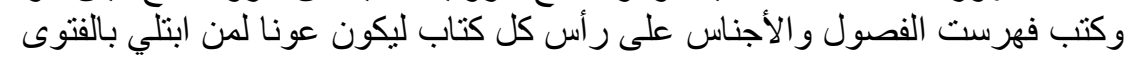

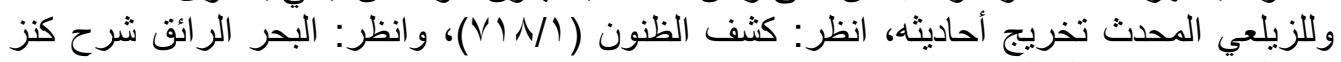


تحقيق مخطوط القول الأحري في الطلاق المعلق علي نفقة العدة بالإبرا للشيخ محمد أمين بن السيد

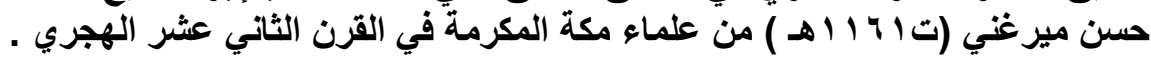

\section{(قف: (فتاء القاضى بنجار (') في هذه المسألة بوقوع)}

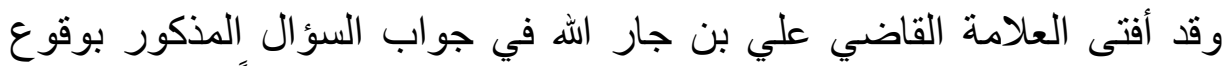

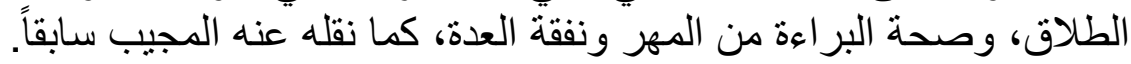

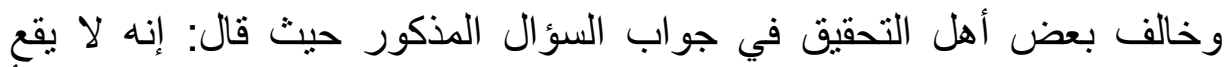

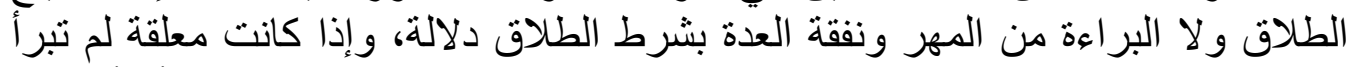

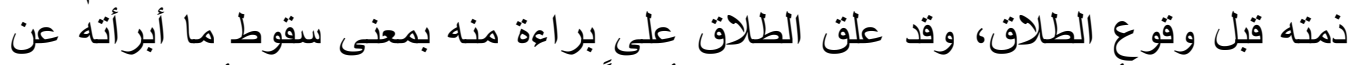

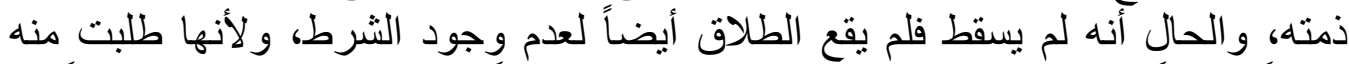

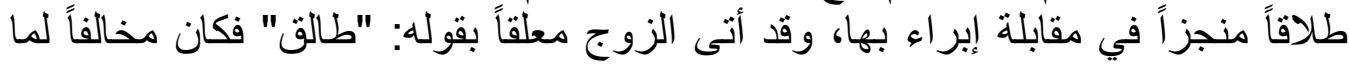
طلبته فلا يقع الطلاق ورلا البراءة إيلة لتوقفها عليه.

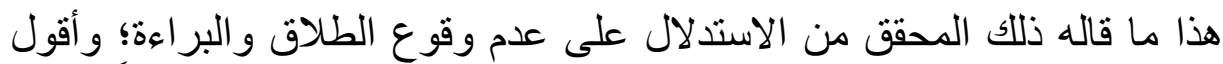

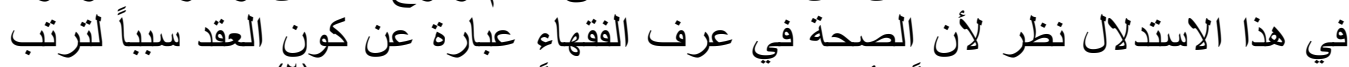

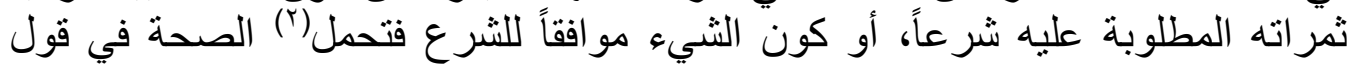

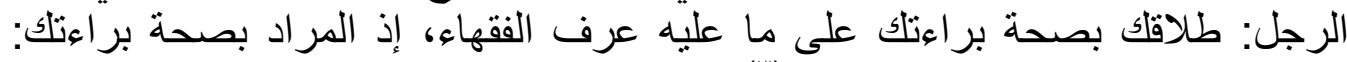

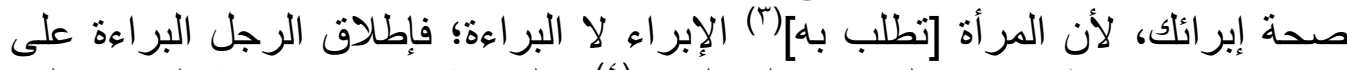

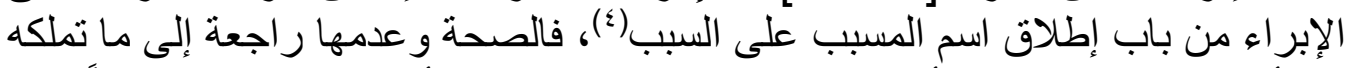

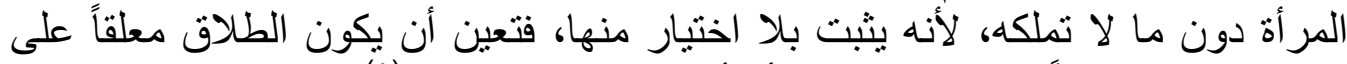

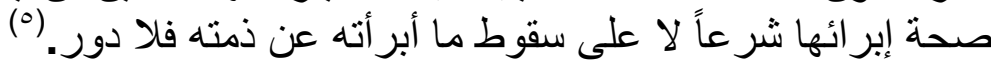
و هذا الذي يقوله الفقهاء في معنى الصحة هو المتبادر من كلام الناس أيضاً، فإنه إنه

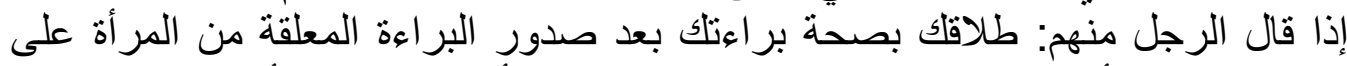

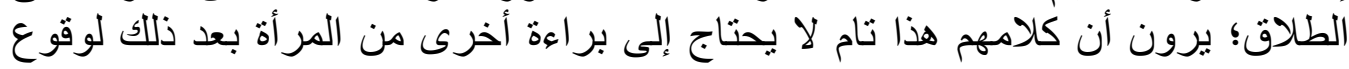

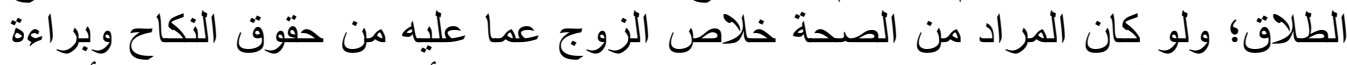

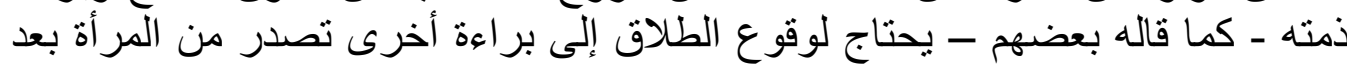

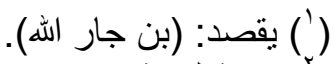

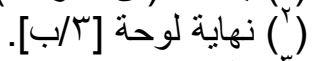

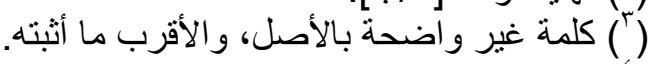

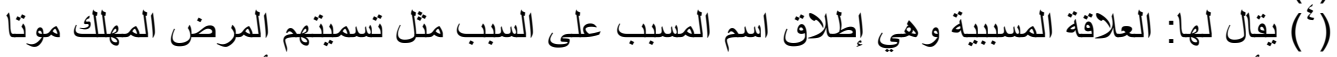

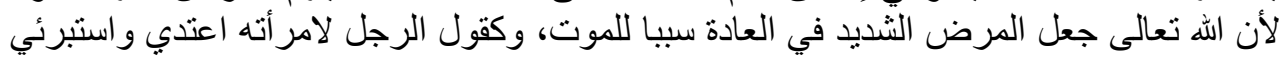

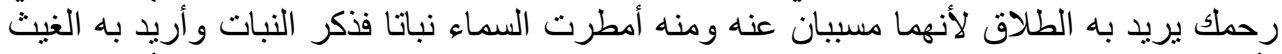

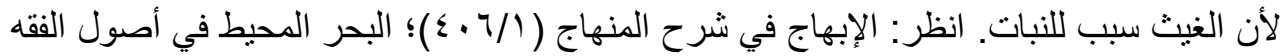
. (005/1)

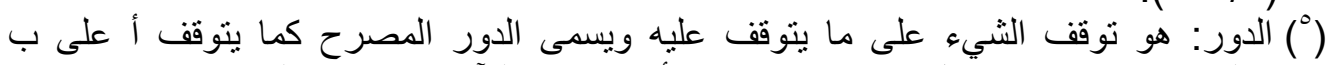

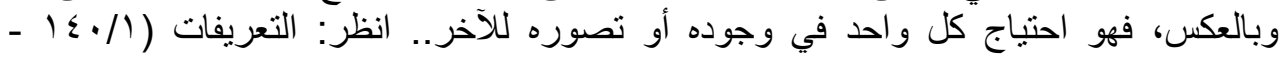


مجلة كلية الثريعة والقانون بتفهنا الأثراف ـ دقهلية العدد الثالث و العشرون لسنة إب ـ بم الجزء الثاني

إيقاع الطلاق من الزوج، لكون الطلاق معلقاً على خلاص ذمته، وهي لم تخلص قبل الطلاق، و هذا خلاف ما هو عند الزون الناس.

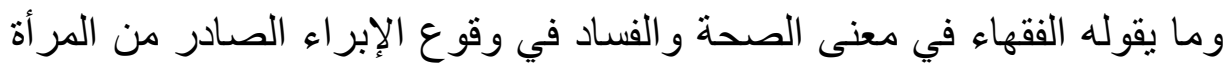

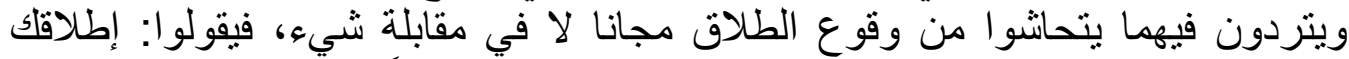
بصحة بر اءتلك أب طلاقكاك؛ واقع بشرط ون صحة إبر ائك لي خوفاً من أن يقع الطلاق منهم وإن لم تصح البراءة.

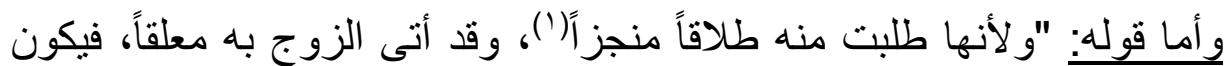

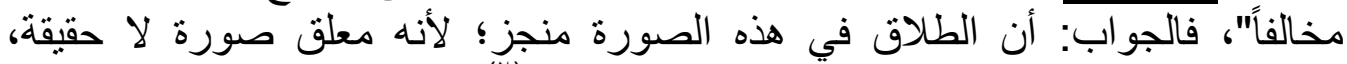

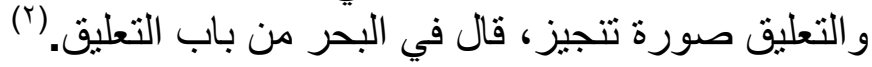

\section{(قف: شرط صحة التعليق)}

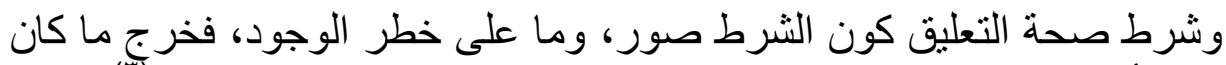

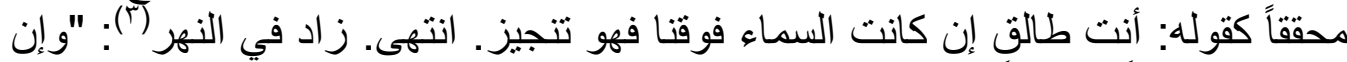

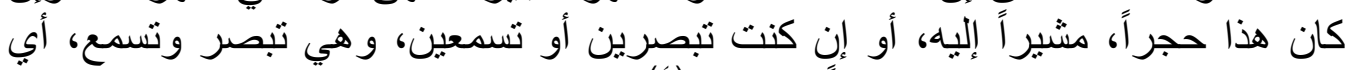

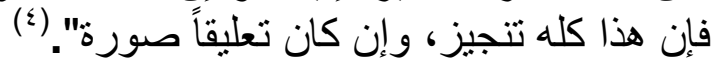

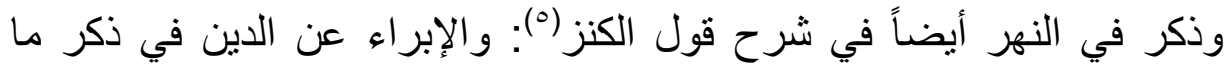

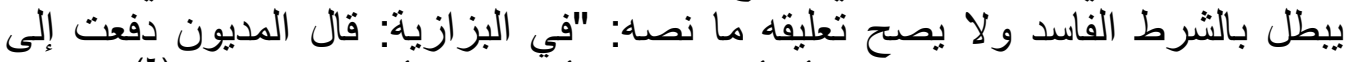

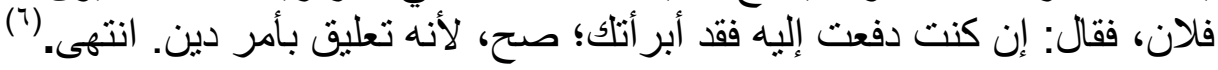

\section{(قف: قول إن صحت براعتكان}

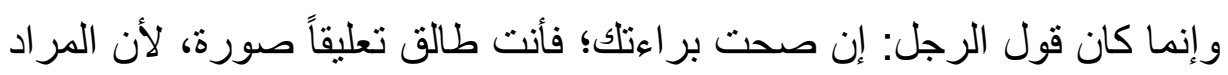
بالصحة في كلام الزوج: الصحة التي هي في عرف الفق الفهاء كما تقدم.

(') الطلاق المنجز : أن بطلقها طلاقا منجزا بصيغة الجزم كقوله: أنت طالق. انظر : معجم لغة الفقهاء

(r9r/l)

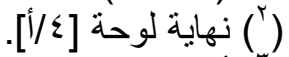

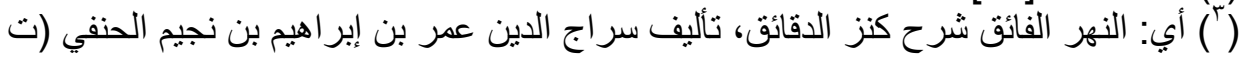

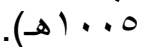

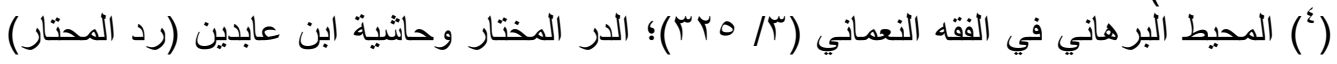

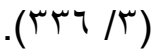

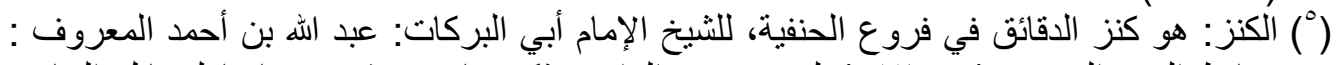

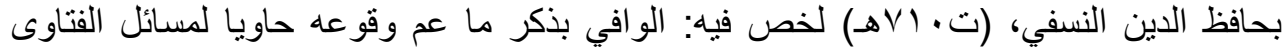

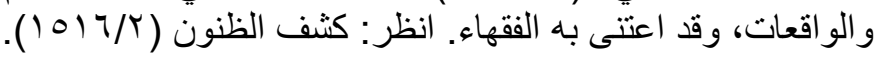


تحقيق مخطوط القول الأحري في الطلاق المعلق علي نفقة العدة بالإبرا للشيخ محمد أمين بن السيد

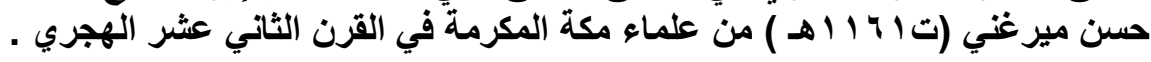

و لاشك أن الصحة بهذا المعنى متحققة في إبرائها قبيل وقوع الطان الطاق من الزوج،

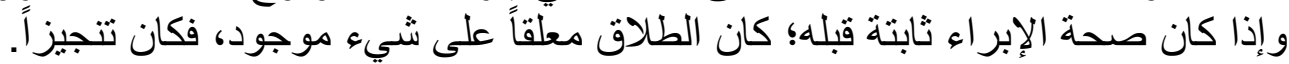

\section{(قف: البراعة من المهر ونفقة العدة صحيحة في السؤال المذكور).}

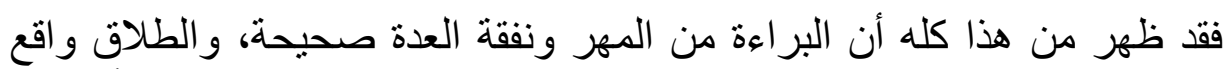

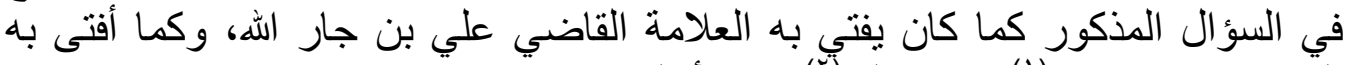

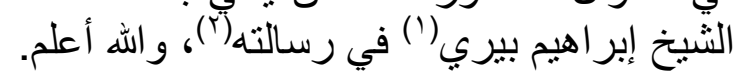

(قف: إذا قال الزوج: أردث في قولى: طلاقّك بصحة براءة خلاص من

الأمة عما أبراء).

بقي ما إذا قال الزوج: أردت بالصحة في قوله: طلاقلك بصحة براءتاعك خلاص

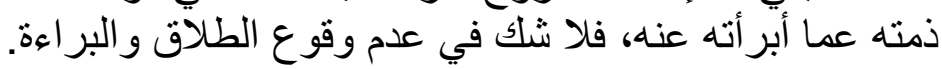

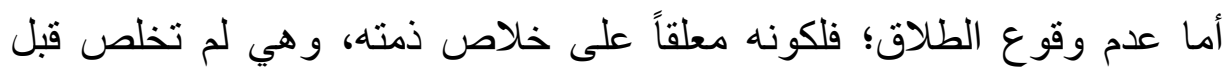

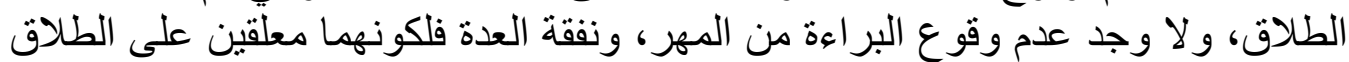

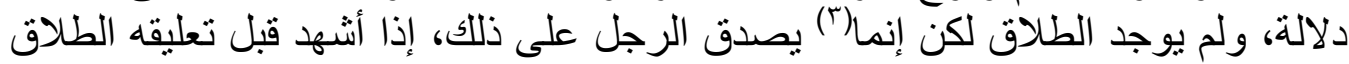

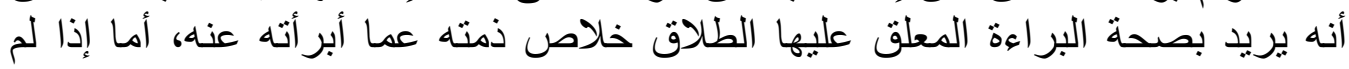

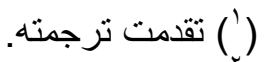

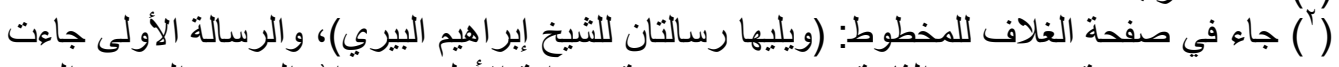

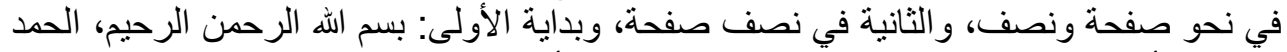

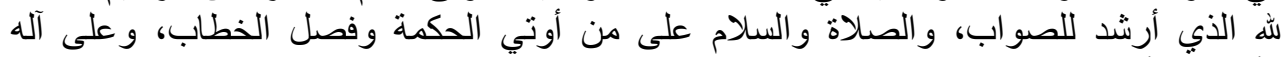

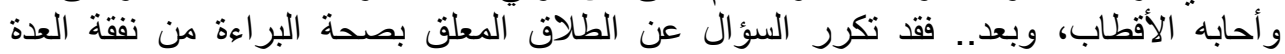

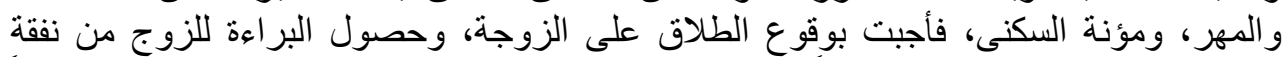

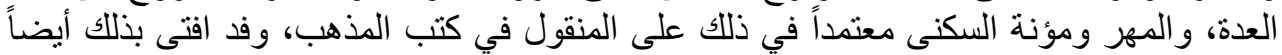

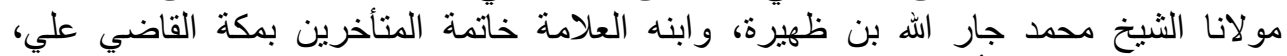

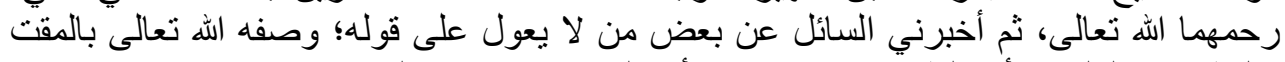

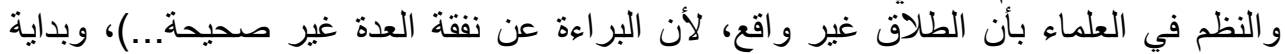

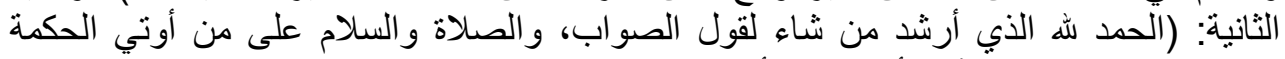

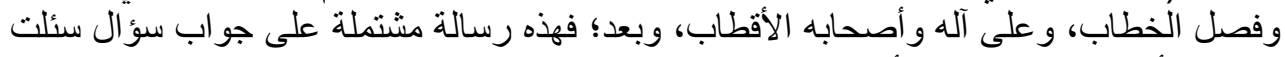

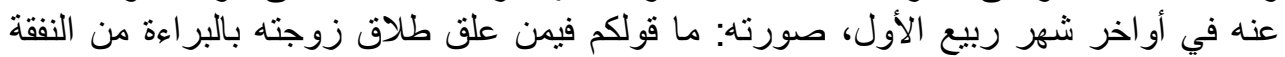

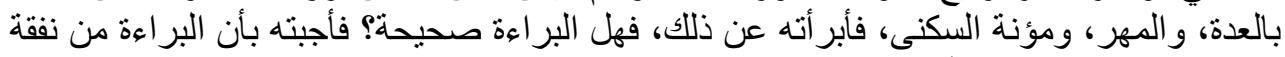

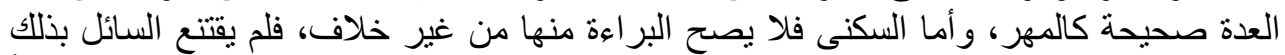

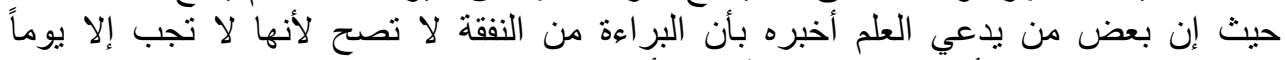

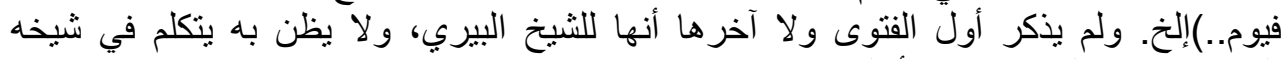

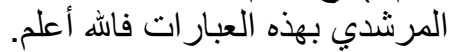


مجلة كلية الثريعة والقانون بتفهنا الأشر اف ـ دقهلية العدد الثالث والعشرون لسنة اب ـ بم الجزء الثاني

يُشهـ قبل ذلك فلا يصدق لأنه أراد خلاف المتبادر من الصحة، وفيه نوع تهمة لكونه

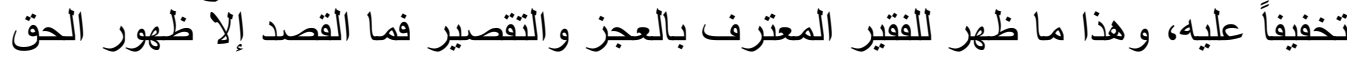

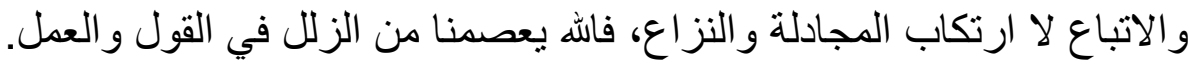
وصلى الله على سيدنا محمد خاتم المرسلين، و على آله وصحبه أجمعين إلى يوم الدين.

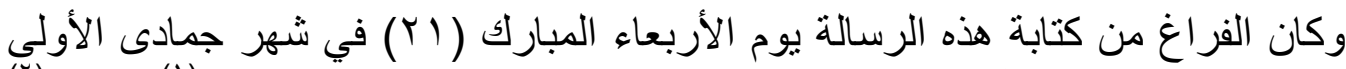

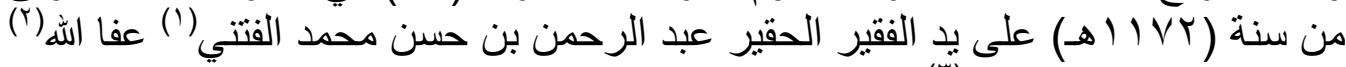

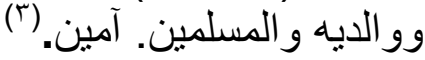




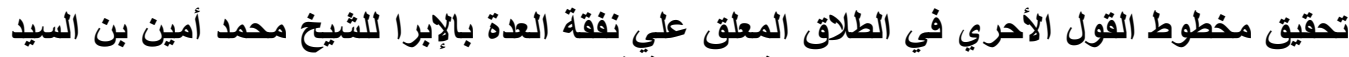

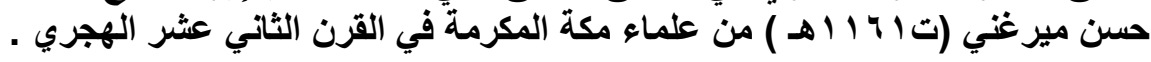

\section{فهرس المصادر والمراجع}

ا.الإبهاج في شرح المنهاج، على منهاج الوصول إلى علم الأصول للبيضاوي،

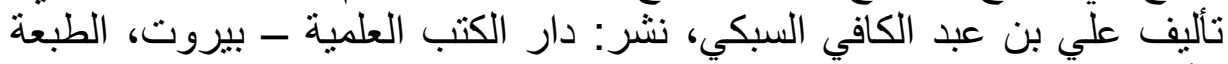

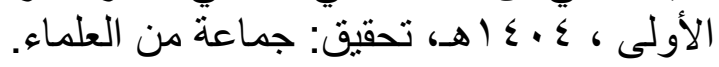

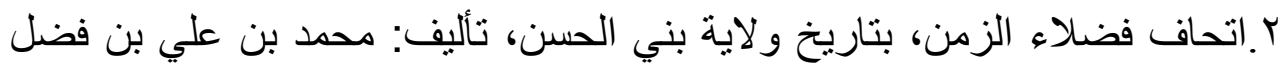

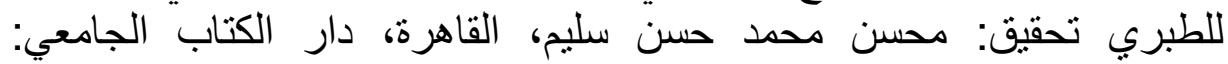
. م) 997

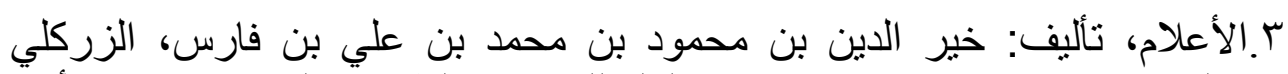

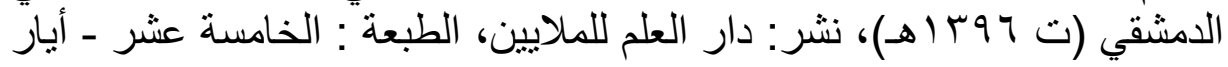

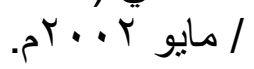

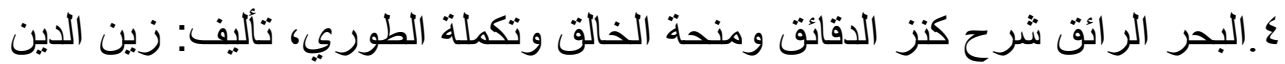

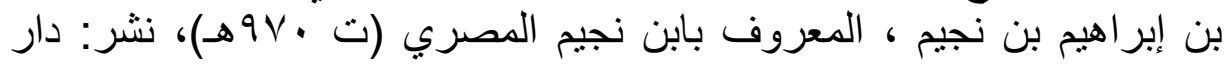

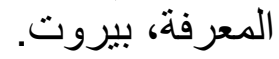

$$
\text { ه.البحر المحيط في أصول الفقه، }
$$

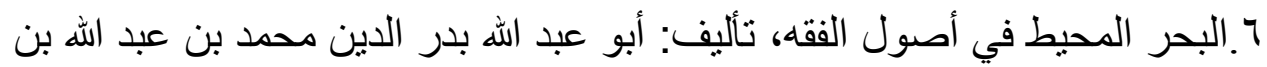

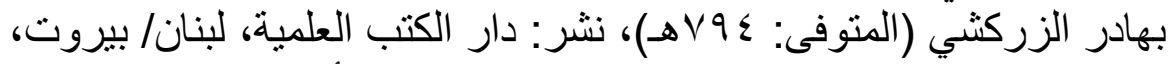

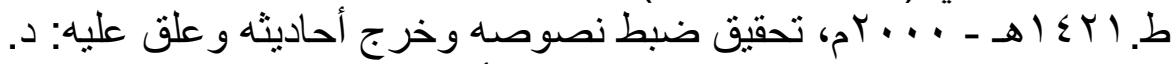

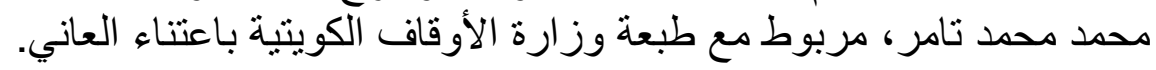

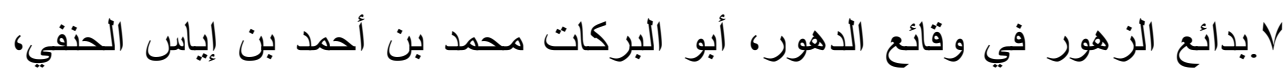

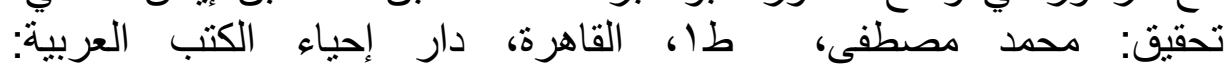

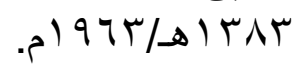

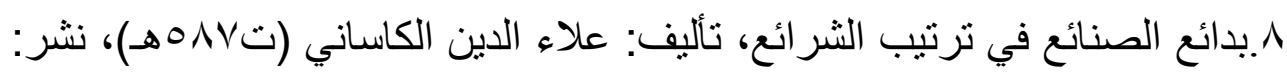

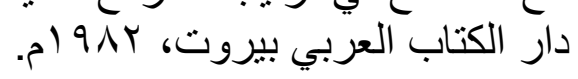

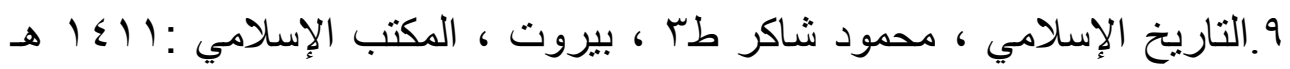
.م) $991 /$

• (.تاريخ الدولة العلية العثمانية، محمد فريد بك المحامي: بيروت، دار الجيل:

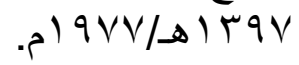


مجلة كلية الثريعة والقانون بتفهنا الأشراف ـ دقهلية العدد الثالث و العشرون لسنة إ ـ ب م الجزء الثاني

ا (إريخ مكة "دراسات في السياسة والعلم والاجتماع و العمران"، تأليف: أحمد

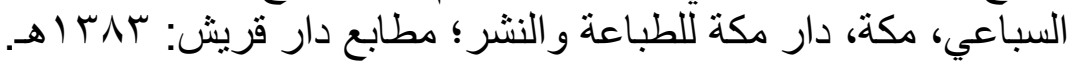

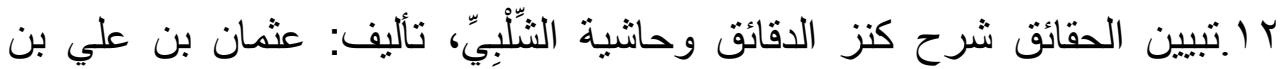

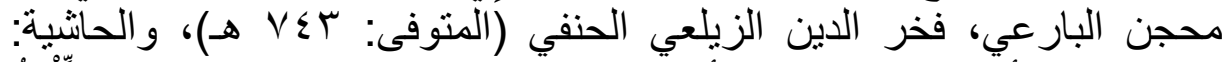

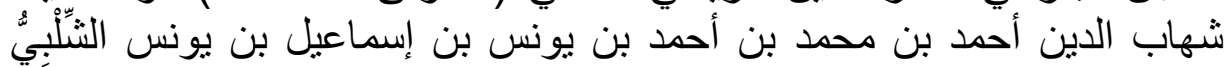

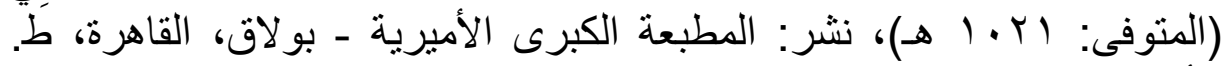

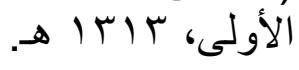

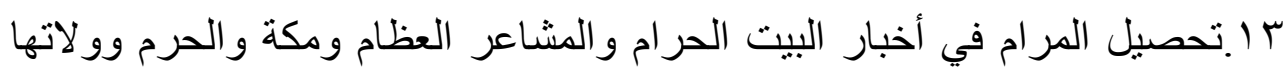

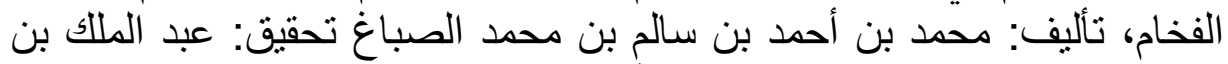

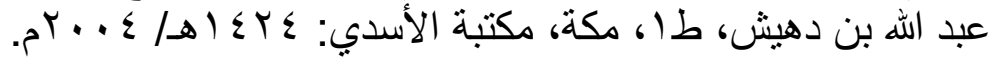

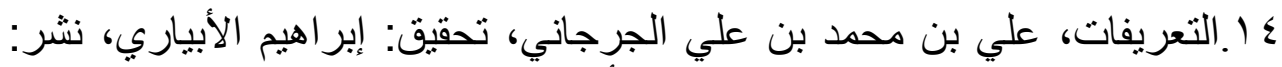

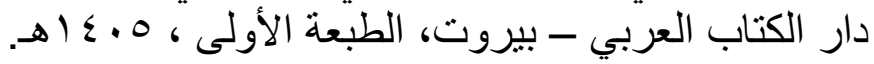

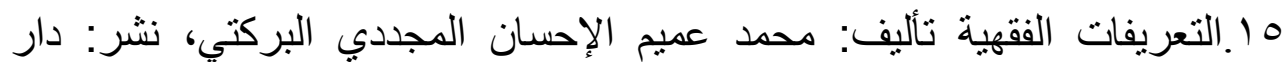

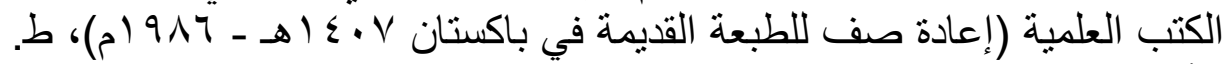

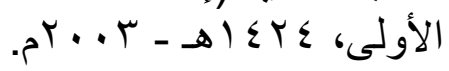

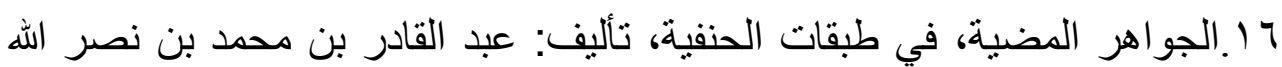

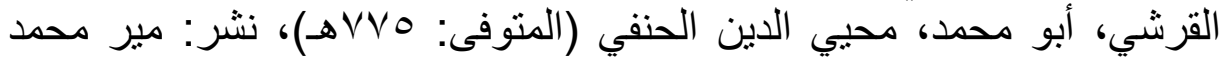

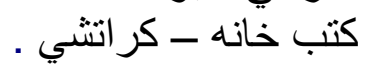

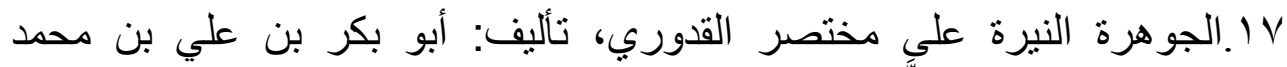

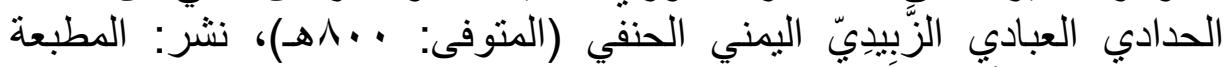

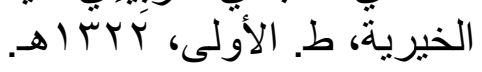

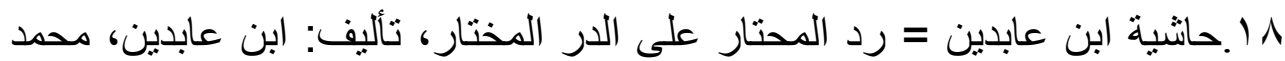

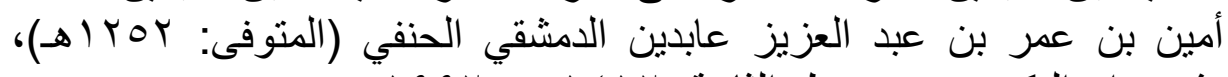

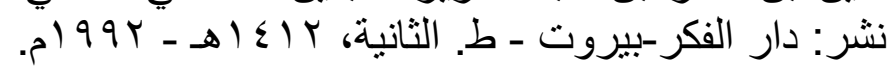

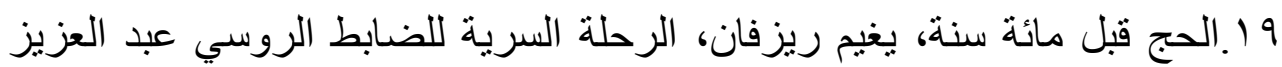

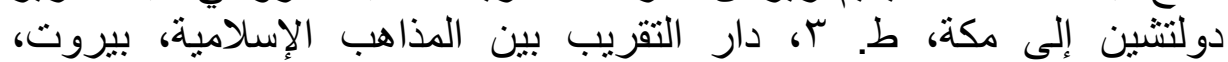

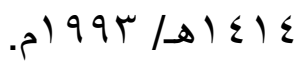


تحقيق مخطوط القول الأحري في الطلاق المعلق علي نفقة العدة بالإبرا للشيخ محمد أمين بن السيد

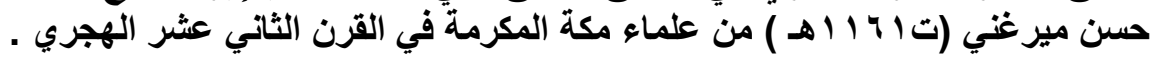

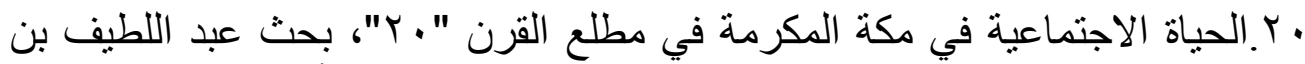

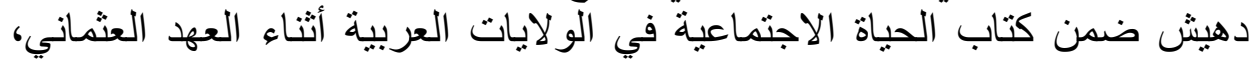

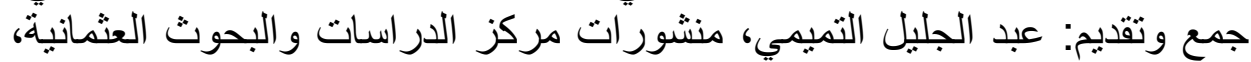

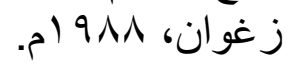

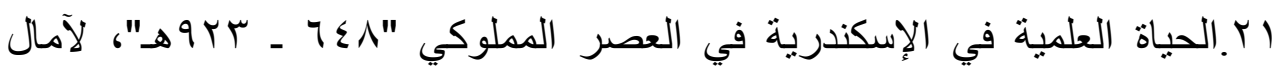

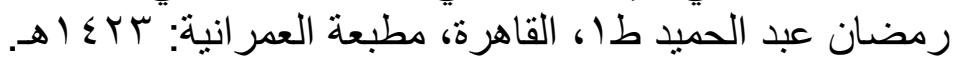

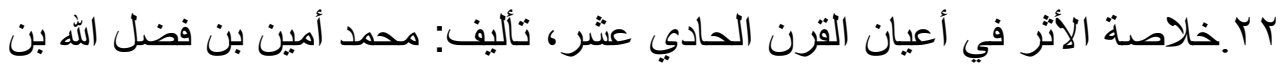

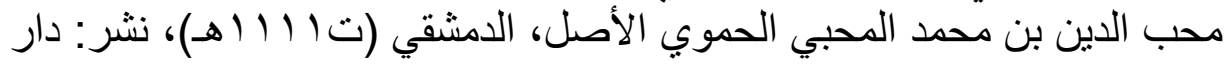

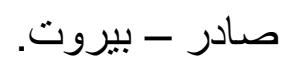

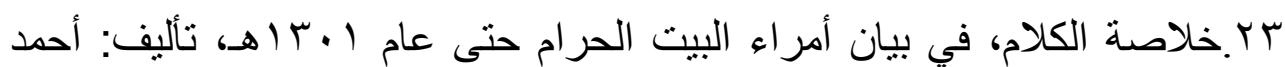

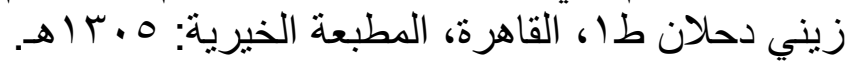

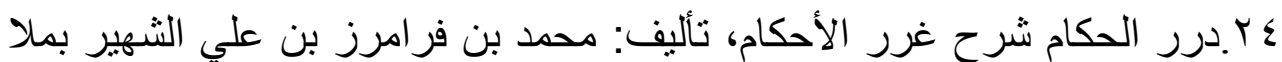

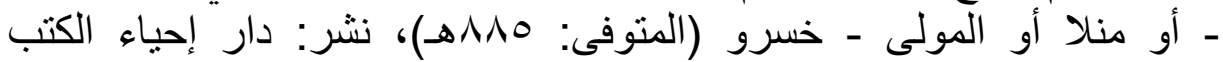

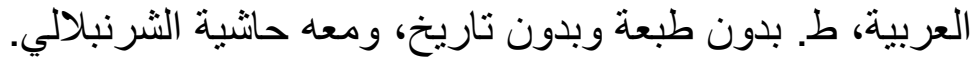
هץ.الدولة العثمانية والمشرق العربي، محمد أنبس طا، القاهرة، مكتبة الأنجلو

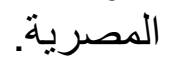

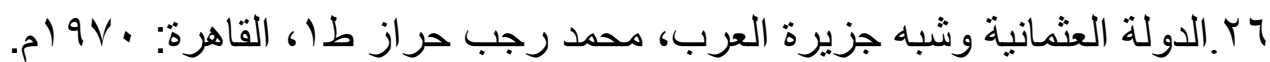

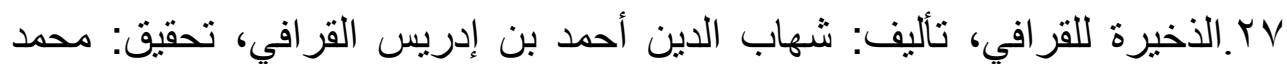

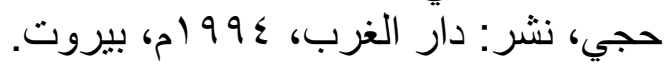

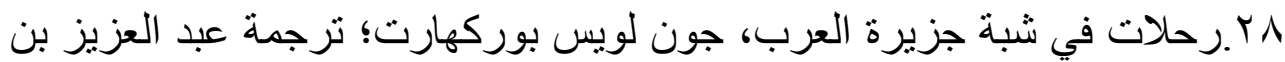

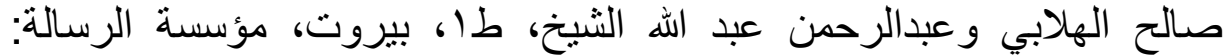

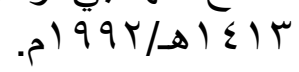

9ץ.الرحلة الحجازية، تأليف: محمد لبيب البتنوني، طب، القاهرة، مطبعة الجمالية:

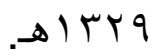

• ب.روضة الطالبين وعمدة المفتين لأبي زكريا محيي الدين بحيى بن شرف النووي

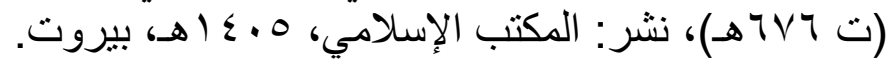

اسبلك الدرر في أعيان القرن الثاني عثر، محمد خليل المرادي بغداد، مكتبة المثنى. - 20 - n 
مجلة كلية الثريعة والقانون بتفهنا الأشراف ـ دقهلية العدد الثالث و العشرون لسنة إץ ـ بم الجزء الثاني

بr.سنن الترمذي = الجامع الصحيح للإمام محمد بن عيسى أبو عيسى الترمذي السلمي، نشر: دار إحياء التراث العربي - بيروت، تحقيق: أحمد محمد شاكر لئري و آخرين.

بr.شذرات الذهب في أخبار من ذهب، تأليف: عبد الحي بن أحمد بن محمد العكري

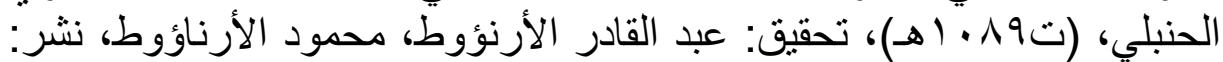

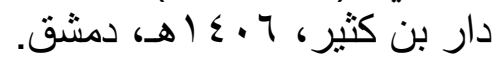

ع ז.الثرح الكبير على منن المقنع، تأليف: عبد الرحمن بن محمد بن أحمد بن قدامة

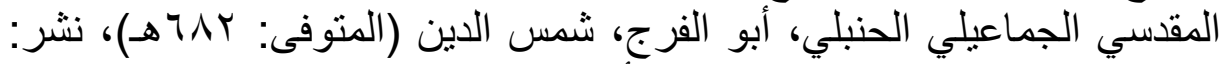
دار الكتاب العربي للنشر والتوزيع، أشرف على طباعته: محمد رشيد رضا صاحب المنار.

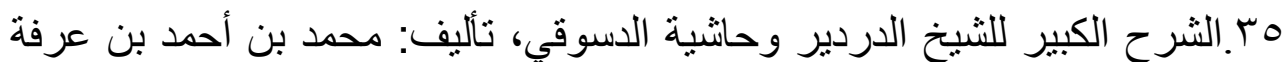

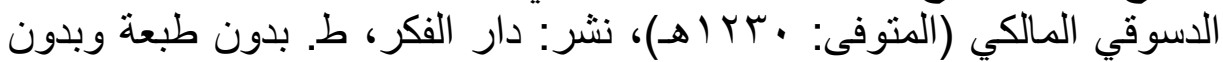

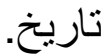

بس.شرح فتح القدير، تأليف: كمال الدين محمد بن عبد الواحد السيو اسي ـ سنة الوفاة

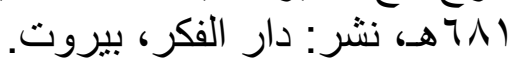

Vr.شرح مسلم للنووي = المنهاج شرح صحيح مسلم بن الحجاج، تأليف أبي زكريا يحيى بن شرف بن مري النووي، نشر: دار إحياء التراث العربي - بيروت، التئ

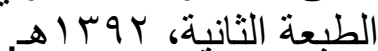

^مبشؤون الحرمين الثريفين في العهد العثماني في ضوء الوثائق التركية العثمانية

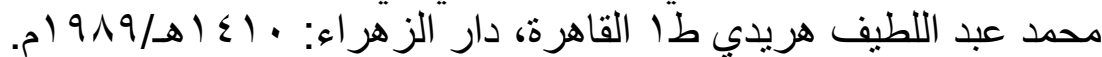

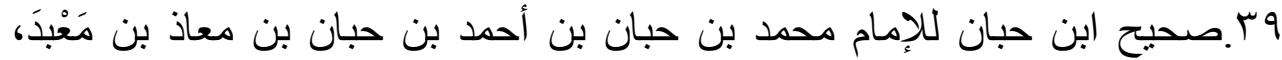

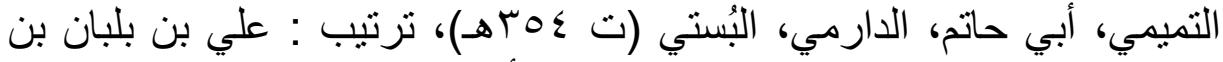

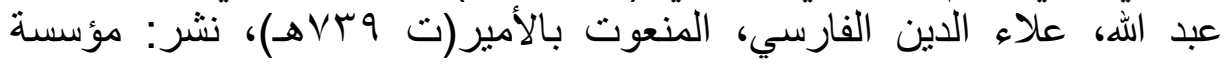

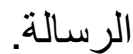

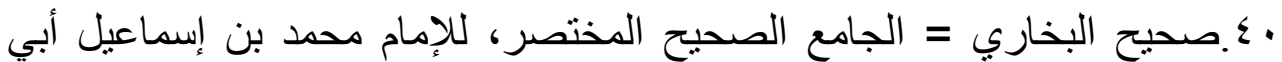

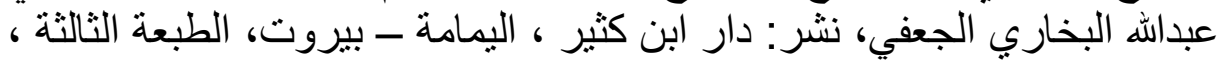

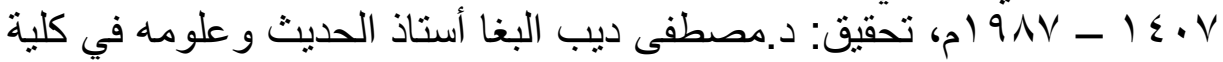
الشريعة - - جامعة دمشق.

اء.صحيح مسلم، للإِمام مسلم بن الحجاج أبو الحسين القشيري النيسابوري، نشر: دار إحياء التراث العربي ـ بيروت، تحقيق: محمد فؤاد عبد الباقي. 
تحقيق مخطوط القول الأحري في الطلاق المطلق علي نفقة العدة بالإبرا للشيخ محمد أمين بن السيد

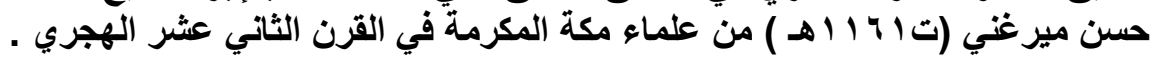

rع.الفروق = أنوار البروق في أنواء الفروق، تأليف: أبو العباس شهاب الدين أحمد

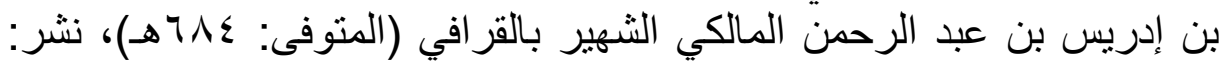

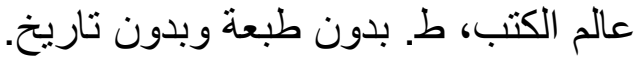

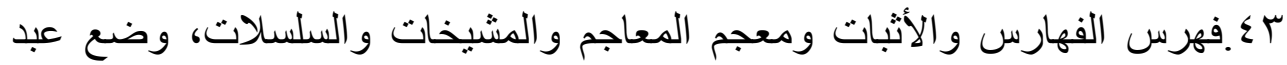
الحي بن عبد الكبير الكتاني، دار الغرب الإنسات ومعامي، بعناية إحسان عباس. ع ـ.الفوائد البهية في تراجم الحنفية، تأليف: أبو الحسنات محمد عبد الحي اللكنوي الهندي

0؛ عنى بتصحيحه وتعليق بعض الزو ائد عليه: محمد بدر الدين أبو فراس النعساني،

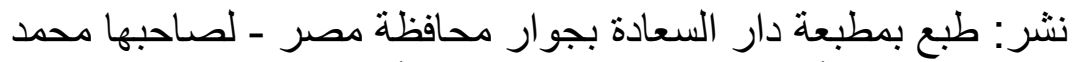

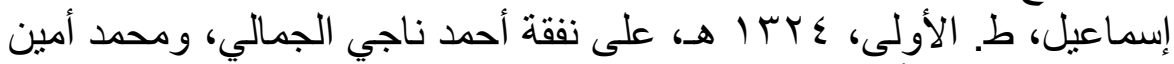

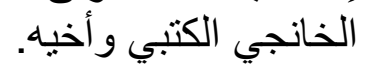

7 ـ.القاموس الفقهي لغة واصطلاحا، تأليف: :سعدي أبو جيب، الناشر :دار الفكر.

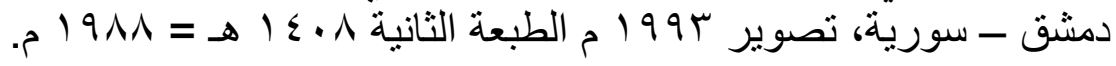

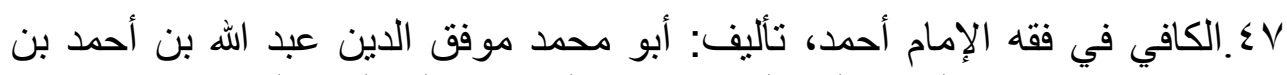

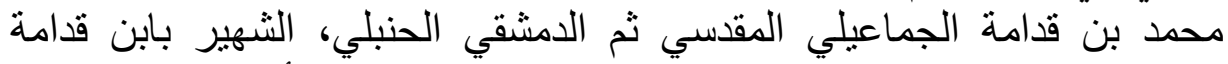

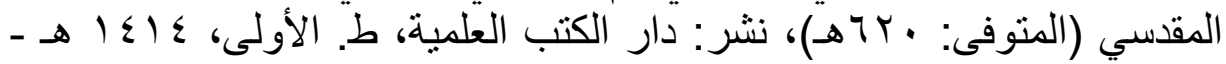
.) $99 \varepsilon$

^ـ كثثف الظنون عن أسامي الكتب والفنون، تأليف: مصطفى بن عبد الله كاتب

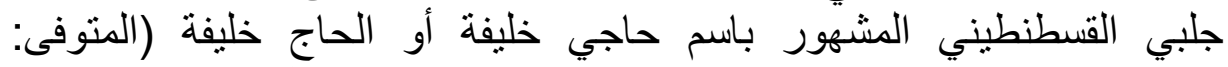

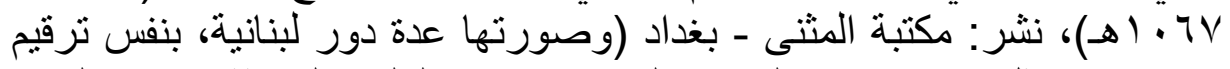

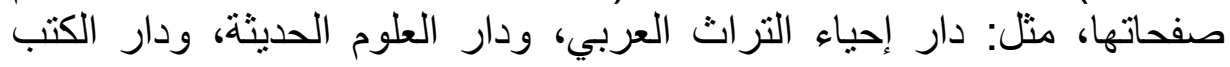

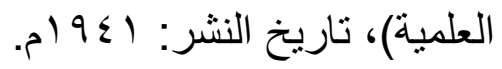

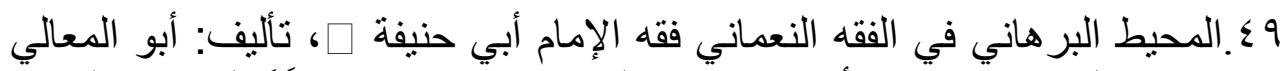

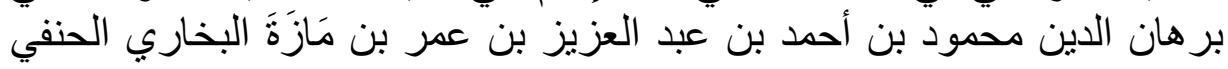

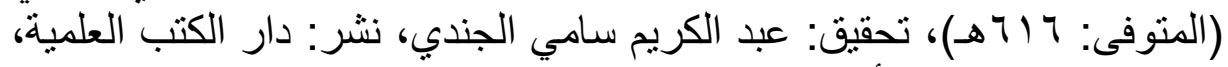

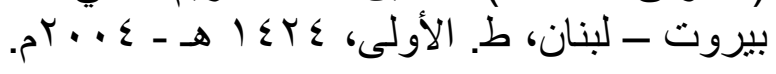

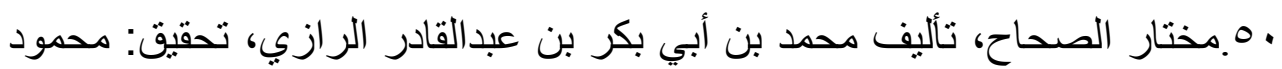

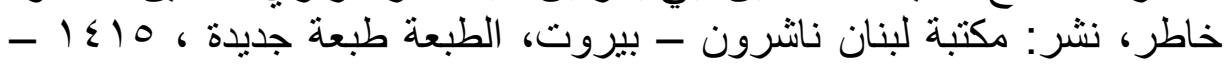


مجلة كلية الثريعة والقانون بتفهنا الأشراف ـ دقهلية العدد الثالث و العشرون لسنة إץ ـ بم الجزء الثاني

1. مختصر نشر النور والزهر في تراجم أفاضل مكة من القرن العانشر إلى القرن

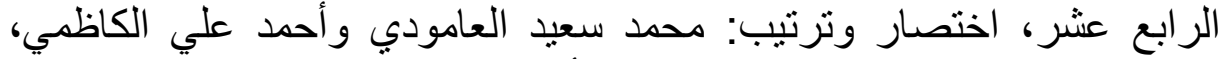

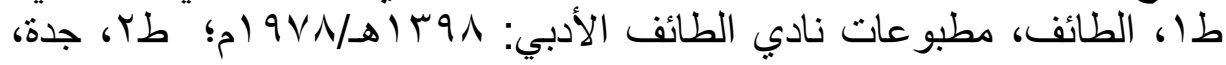

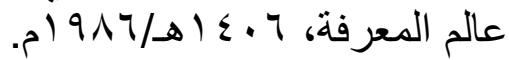

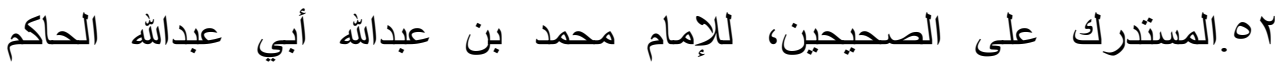

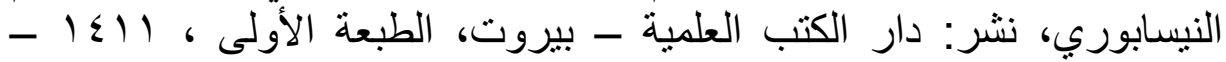
999 19. تحقيق: مصطفى عبد القادر عطا. به. المسجد الحر ام في ضوء الكتاب والسنة للباحث محمد فريد الدين راثد، (رسالة ماجستير غير منشورة، كلية الثريعة والبه والدراسات الإسلامية، جامعة ألم القرى،

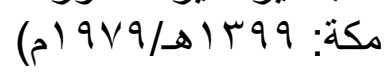

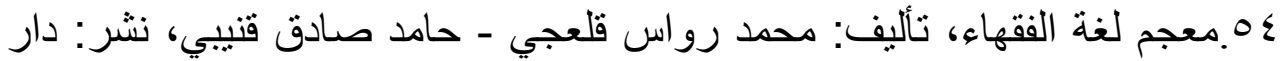

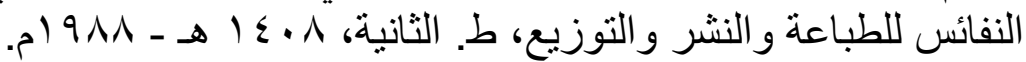

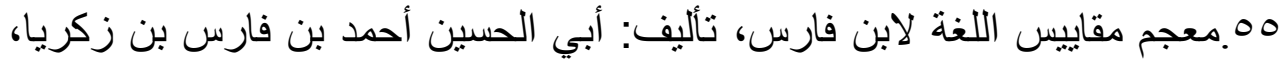

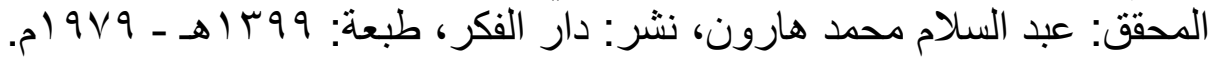

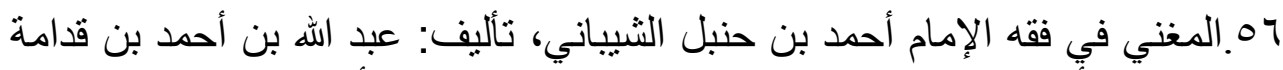

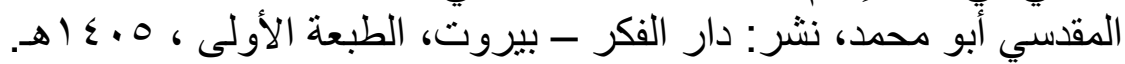

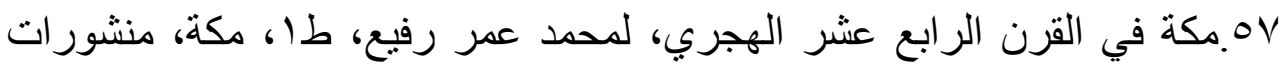

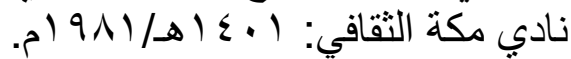

هـمنائح الكرم في أخبار مكة والبيت ووولاة الحرم علي بن تاج الدين بن تقي الدين

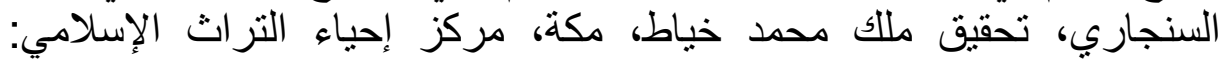

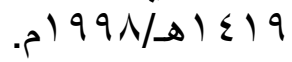

هو.موسوعة الأعلام، تراجم موجزة للأعلام، تأليف: موقع وزارة الأوقاف

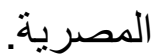

ـ ا.الموسوعة الفقهية الكويتية، صادر عن : وزارة الأوقاف والثئون الإسلامية ـ الكويت

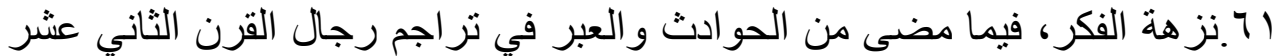

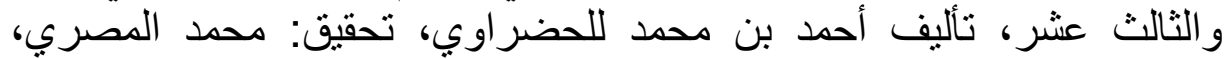
دمشق، وزارة الثقافة: 999 (م. 


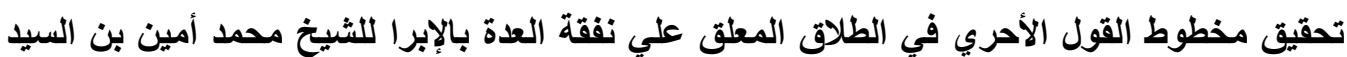

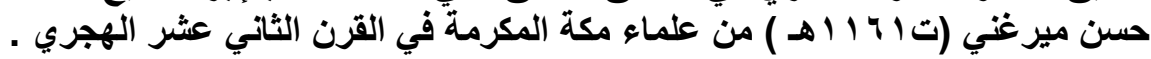

بT.النهاية في غريب الحديث والأثر، لأبي السعادات المبارك بن محمد ابن الأثير

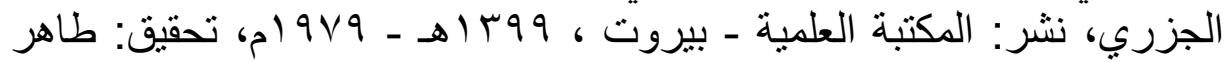

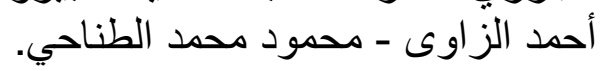

با.النهر الفائق شرح كنز الدقائق، تأليف: سراج الدين عمر بن إبراهيم بن إهن نجيم

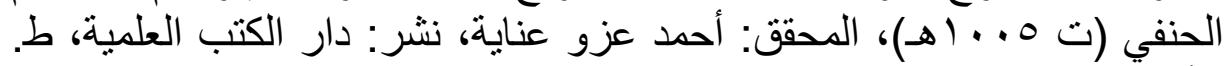

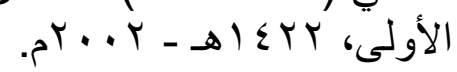

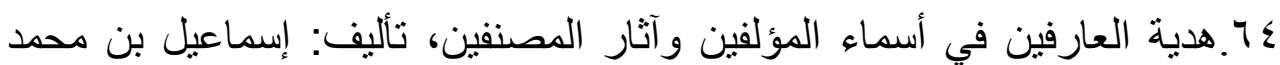

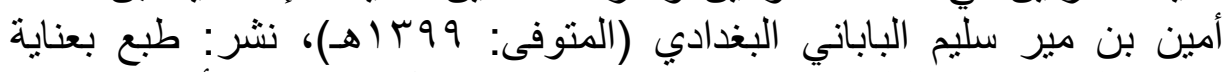

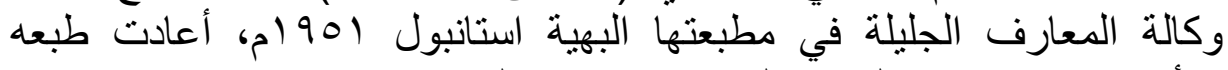
بالأوفست: دار إحياء التراث العرات العربي بيروت ــ لبنان.

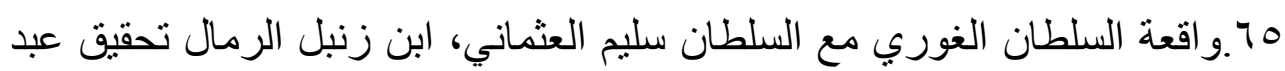

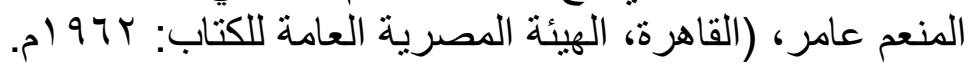

$$
\text { المكتبات الإكترونية: }
$$

7 7 .المكتبة الثاملة الإصدار

$$
\text { المواقع الإلكترونية: }
$$

https://www.dorar.net/firq ‘/

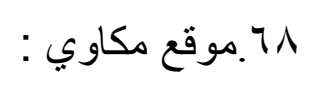

http://forum.makkawi.com/archive/index.php/t-75984.html.

$$
\text { 9 } 79 \text {. مقال بالفيسبوك : }
$$

/https://www.facebook.com/1456002037970671/posts

$$
. / 1.0994 T V T r \cdot \varepsilon \wedge V V
$$

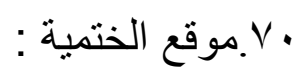

https://www.khatmiya.com/vb/showthread.php?trro= 